\title{
Neurocosmetics in Skincare-The Fascinating World of Skin-Brain Connection: A Review to Explore Ingredients, Commercial Products for Skin Aging, and Cosmetic Regulation
}

\author{
Vito Rizzi $^{1, *(\mathbb{D})}$, Jennifer Gubitosa ${ }^{1}\left(\mathbb{D}\right.$, Paola Fini $^{2}(\mathbb{D})$ and Pinalysa Cosma ${ }^{1, *(D)}$ \\ 1 Dipartimento di Chimica, Università degli Studi “Aldo Moro" di Bari, Via Orabona, 4-70126 Bari, Italy; \\ jennifer.gubitosa@uniba.it \\ 2 Consiglio Nazionale delle Ricerche CNR-IPCF, UOS Bari, Via Orabona, 4-70126 Bari, Italy; p.fini@ba.ipcf.cnr.it \\ * Correspondence: vito.rizzi@uniba.it (V.R.); pinalysa.cosma@uniba.it (P.C.)
}

check for

updates

Citation: Rizzi, V.; Gubitosa, J.; Fini,

P.; Cosma, P. Neurocosmetics in

Skincare-The Fascinating World of

Skin-Brain Connection: A Review to

Explore Ingredients, Commercial

Products for Skin Aging, and

Cosmetic Regulation. Cosmetics 2021,

8, 66. https://doi.org/10.3390/

cosmetics 8030066

Academic Editor: Leonhard Zastrow

Received: 9 June 2021

Accepted: 12 July 2021

Published: 16 July 2021

Publisher's Note: MDPI stays neutral with regard to jurisdictional claims in published maps and institutional affiliations.

Copyright: (c) 2021 by the authors. Licensee MDPI, Basel, Switzerland. This article is an open access article distributed under the terms and conditions of the Creative Commons Attribution (CC BY) license (https:/ / creativecommons.org/licenses/by/ $4.0 /)$.

\begin{abstract}
The "modern" cosmetology industry is focusing on research devoted to discovering novel neurocosmetic functional ingredients that could improve the interactions between the skin and the nervous system. Many cosmetic companies have started to formulate neurocosmetic products that exhibit their activity on the cutaneous nervous system by affecting the skin's neuromediators through different mechanisms of action. This review aims to clarify the definition of neurocosmetics, and to describe the features of some functional ingredients and products available on the market, with a look at the regulatory aspect. The attention is devoted to neurocosmetic ingredients for combating skin stress, explaining the stress pathways, which are also correlated with skin aging. "Neuro-relaxing" anti-aging ingredients derived from plant extracts and neurocosmetic strategies to combat inflammatory responses related to skin stress are presented. Afterwards, the molecular basis of sensitive skin and the suitable neurocosmetic ingredients to improve this problem are discussed. With the aim of presenting the major application of Botox-like ingredients as the first neurocosmetics on the market, skin aging is also introduced, and its theory is presented. To confirm the efficacy of the cosmetic products on the market, the concept of cosmetic claims is discussed.
\end{abstract}

Keywords: neurocosmetics; neurocosmetic ingredients; skin care cosmetics; skin aging; skin stress; anti-wrinkle; cosmetics; sensitive skin; Botox-like ingredients

\section{Introduction \\ Skin and Brain: A Psychobiological Concept}

The skin, a wonderful and complex organ, manages the relationships between us and the outside world. It provides information that allows us to analyze, examine, and monitor its status-to understand and know it. The skin can appear as a canvas on which a large part of our interior world is painted: it is a dynamic structure, in continuous transformation, that expresses subjective psychological contents through which emotions take shape [1]. The French writer and poet Paul Valéry, in a literary dialogue that binds the deep to the surface being reported: "What is most deep in man is the skin." [2,3]. So, the concept of skin is more complex than we can expect and, if at first glance the skin's surface can be considered to be a passive barrier, on the contrary, it is more than just what the eye can see, and it is far from this concept $[4,5]$. Indeed, the skin is directly connected to the central nervous system, and it can be considered a living sensory receptor organ [6,7]. The Italian dermatologist Emiliano Panconesi reported the interesting and complex concept of a "reunification of the two ectodermal brothers, brain and skin", to indicate the whole sensations that arise from the contact between one's own skin and that of others [1]. As well described by Andrea Bovero, in his Dermocosmetology manual, the skin and the nervous system's common origin deeply influences the relationship that we have with ourselves and others. Touch is the sense linked to the skin, and requires constant contact between the touching body and element 
touched: this contact generates deep sensations that translate into emotions that, in turn, can be perceived and communicated to others. Thus, hands represent the virtual extensions of one's interiority [1]. The French psychoanalyst Didier Anzieu, in his works The Skin Ego, A Skin for Thought, and Psychic Envelopes, developed a theory of the unconscious connection between the human skin's protective and the coordinative ego functions. With this approach, Anzieu reported the surface of the body - the skin - as a key constituent of the mental structures and functions [8].

Starting from these physiological functions (containing/retaining, separating/communicating), Bovero reported Anzieu's concept, and The Skin Ego acquires the dual possibility to establish barriers and filter exchanges with the outside [1]. Just as the cell membranes delimit the cells, ensuring their individuality, similarly The Skin Ego guarantees the body's individuality, differentiating it from others, enhancing and safeguarding the self-identity. It is easy to understand that, if the skin represents an extension of the central nervous system, some skin manifestations could result from psychological discomfort [1]. For example, during facial dermatoses, such as seborrheic dermatitis or rosacea, some neuromediators could play an important role, and since sensitive skin clinically results in vasodilation and pain, it is probably linked to neuronal hyperactivation. Moreover, Misery reported that the nervous system is involved in many dry skin problems and delayed healing [9]. Furthermore, Bovero described this concept as more complex, and the origin of psychosomatic skin disease could also be sought in early childhood [1]. On the basis of these considerations, it clearly appears plausible that the healing of several skin diseases could be improved through the combination of specific psychotherapeutic treatments [10], and this concept has its root in 1925, with the dermatologist Joseph Klauder. In other words, if the skin is a seismograph that reproduces the psychological self-condition, on the other hand, the body can choose to respond somatically to the different situations of anxiety and stress. Sometimes, these are normal skin reactions that quickly pass-such as a hot flash that accompanies a moment of embarrassment-but dermatological manifestations that evolve into real pathologies are often observed. Therefore, the most common skin diseases can also have psychosomatic origins and-for example-dermatitis, psoriasis, and some dermal allergies can be taken into consideration. As a result, this psychobiological concept moved towards a self-consistent medical-scientific discipline identified as psycho-neuro-endocrine-immunology (PNEI); as reported by Bovero (2011) and França et al. (2017), PNEI can be defined as the study of the relationship between the psyche and the nervous, endocrine, and immune systems $[1,10]$.

The studies performed in this "new" and fascinating field are radically transforming the human approach and research, moving progressively from a sectorial vision of the different organs, considered as independent systems, to a global vision of the wide network of hormones, cytokines, and neuropeptides that closely connect mind and body. Once again, as well described by Bovero, the skin, nervous system, and immune system are integrated into a single network that is defined as the neuro-immuno-cutaneous system (NICS). [1] This interesting relationship between the skin and the nervous system was for a long time neglected, but today represents one of the most important fields investigated in skin biology. The associations between nerve fibers and skin are very close from an anatomical and physiological point of view, and these can be observed at the cellular level [11,12]. The complex concept related to "skin identity" clearly arises from these considerations, evidencing the skin's importance not only because it acts as a protective barrier against external aggressors [8,13], but also for its connection with the brain. Furthermore, it is worth mentioning that undamaged and intact skin is more attractive from an aesthetic point of view, and it confers a youthful aspect [14]. Since good health also considers the improvement of the skin's appearance, the use of safer and more effective cosmetic products as a strategy, especially for combating skin aging, has progressively increased over the years [15]. Indeed, with the increasing longevity of the worldwide population, good health has become essential for a better quality of life, even in advanced age. Hence, the skin becomes the target of any cosmetic product; as reported in Article 2.1 (a) of the 
European Regulation (EC) No 1223/2009: "any substance or mixture intended to be placed in contact with the external parts of the human body (epidermis, hair system, nails, lips..) with a view exclusively or mainly to cleaning them, perfuming them, changing their appearance, protecting them, keeping them in good condition or correcting body odors". [15]. Thanks to the aim of preserving wellbeing over time, a cosmetic product should be considered a powerful tool that breaks down the barrier between beauty and health; for this reason, cosmetics are largely used not only by beauty experts, but also by regular people throughout the day [16]. There are different cosmetic forms on the market, each with its own function and different ingredients, which are used in novel products, meeting ancient traditions and recent innovations, with the purpose of restoring and improving skin blemishes. However, as already discussed, since these imperfections-generated by an external and internal discomfort-are the consequence of some phenomena of a physio-pathological nature (which manifest themselves on the skin, and are reflected at the physical, psychological, and social levels) [1], the concept of "traditional" cosmetics has been overpassed in the last years, looking instead for skincare products able to affect skin-brain connections: these are neurocosmetics. They generate many doubts when confused with the neurosciences or the wellbeing and hedonistic feelings arising from the use of cosmetic products. Thus, this review aimed to clarify these ambiguous concepts, contextualizing the applications of neurocosmetics. The review is opened by briefly describing the well-known cosmetic functions and uses that have been regulated for years, then landing in the neurocosmetic world, presenting it carefully. With the aim of understanding some general concepts about the functions of neurocosmetics, ingredients available on the market for a skincare beauty routine will be examined. The connection between skin and brain will be thus explored, along with a view on skin aging, offering an overview of what is known about this fascinating neurocosmetic research field, and what is still ambiguous. Finally, some aspects of cosmetic claims and efficacy, safety assessment, and regulation of cosmetic products, in order to frame the regulation of neurocosmetics, will be further discussed.

\section{A Brief Overview: From Cosmetology and Cosmetic Functions to Neurocosmetics}

In agreement with the European Regulation (EC) 1223/2009, cosmetic products are designed for a specific use, and equipped with several features that they can exhibit through different mechanisms of action [16]. Cosmetology is the science that studies the cosmetics' mechanisms of action and their biological effects in humans, defining how to use them.

In particular, the field of functional cosmetics aims to formulate products for restoring the normal skin balance, preventing or counteracting the onset of any blemishes. It is worth mentioning that the physiological balance is a dynamic condition; thus, it does not refer to a situation in which transformation processes do not take place (static balance), but to a system in which transformation processes continuously occur under dynamic equilibrium. When the skin is examined, as for any other organ, it should be thought of as a system in which several biochemical reactions take place, ensuring the life of cells and tissues. As a result, under normal physiological conditions, all of these reactions are in equilibrium with one another. However, in particular situations, this equilibrium can be lacking, with different consequences on the skin (for example, changes in $\mathrm{pH}$, alterations in the water content, changes in the composition of the hydrolipidic film, and so on) [1]. In general, our organism is able to self-restore its normal "physiological" conditions but, in some cases, the imbalances get worse, encouraging the onset of blemishes or real pathologies. Therefore, several cosmetic treatments represent useful tools for ameliorating some skin manifestations, such as acne [1]. However, cosmetics must not claim therapeutic properties, but should protect the skin, keeping it in good condition and carrying out preventive activities [17-20].

Although cosmetics are formulated with many ingredients with different functions, it is possible to distinguish them into three main classes, according to their prevalent function: skincare (protective/nourishing function), makeup (aesthetic/decorative function), and toiletries (hygienic/cleansing function). In particular, the cosmetic functions allow us to 
classify different products according to their activity performed at the skin or mucosal level.

By focusing the attention on the skincare category, which represents the topic of this review, this class includes all products that aim to preserve, over time, the physiological and functional skin characteristics of the area where they are applied. However, since modern cosmetology is mainly oriented towards the formulation of products with "mixed functions", referring to a broad spectrum of activities, it is clear that these differences are obsolete. Starting from these considerations, the boundary between the different cosmetic functions is narrowing; there is a tendency towards a general concept of cosmetics in which beauty and wellbeing become essential both for skin health maintenance and for the prevention of skin blemishes and diseases. Focalizing the attention on the action exhibited by different cosmetic ingredients, it is possible to identify [1]:

- Anti-aging action: this refers to all ingredients that, via different pathways, combat the skin aging processes, preventing and fighting the signs of aging, revitalizing senescent skin, promoting the elimination of toxins, improving microcirculation, and reducing the number and the depth of wrinkles;

- Antioxidant action: this includes ingredients that can capture and inactivate free radicals at the skin level, reducing the "oxidative stress";

- Anti-wrinkle action: this concerns ingredients that counteract the onset of wrinkles;

- Depigmenting action: this includes ingredients that lighten the skin color;

- Eudermic action: this considers ingredients that invoke a feeling of wellbeing when applied on the skin;

- Eutrophic action: this refers to substances that nourish the skin and improve its appearance;

- Soothing, anti-redness action: exhibited by ingredients able to soothe pain and reduce skin redness in cases of mild inflammation, counteracting irritation, and bringing relief to stressed skin;

- Regenerating action: this refers to ingredients with eutrophic properties, promoting cell regeneration, and providing the necessary elements for skin development and maintenance over time;

- Toning, "lifting" action: this concerns ingredients that restore skin tone and firmness by acting at both the epidermis and dermis levels, encouraging the typical turgor of young and healthy skin [1].

Interestingly, recent research advances against skin aging have developed innovative products $[14,15]$ - the so-called neurocosmetics — that could revolutionize the cosmetic world due to their fascinating properties. The first definition of these very interesting products was attributed to Prof. Misery in 2000, referring to them as "not absorbed products applied on the skin, exhibiting activity on the cutaneous nervous system or in general effects on the skin mediators" [9]. So, neurocosmetics are nontoxic, bioactive topical products that contain ingredients designed to work at a neurological level [5], and not elsewhere [21,22].

Furthermore, today, consumers are looking for "technological" skincare products that could prevent skin aging, protect skin from environmental damage, and provide cosmetic options for several skin problems. In particular, consumers' preference is devoted to the research of natural, non-irritating, preservative-free, and green products. Hence, it should be mentioned that the challenges of manufacturers are devoted to the development of safe, stable, and effective products that, at the same time, are eco-sustainable and meet consumer demands [23].

The most common ingredients are botanicals, marine extracts, peptides, and vitamins as antioxidants [2].

On these grounds, in the following paragraphs, a careful discussion is presented about neurocosmetics, offering to the readers an overview of their actions at the skin level and the related important mechanisms that can be affected by their use. 


\section{The Neurocosmetics}

3.1. Towards Neurocosmetics and How to Understand It: A More in-Depth Insight about Skin Innervation and Neurotransmitters

Skin is constituted by the epidermis-the outer, waterproof, stratified, squamous epithelium layer of ectodermal origin - and dermis, the inner and thicker supporting layer of connective tissue of mesodermal origin (Figure 1) [24,25]. A dense innervation involves the outermost skin layers, except for the stratum corneum $[9,25]$.

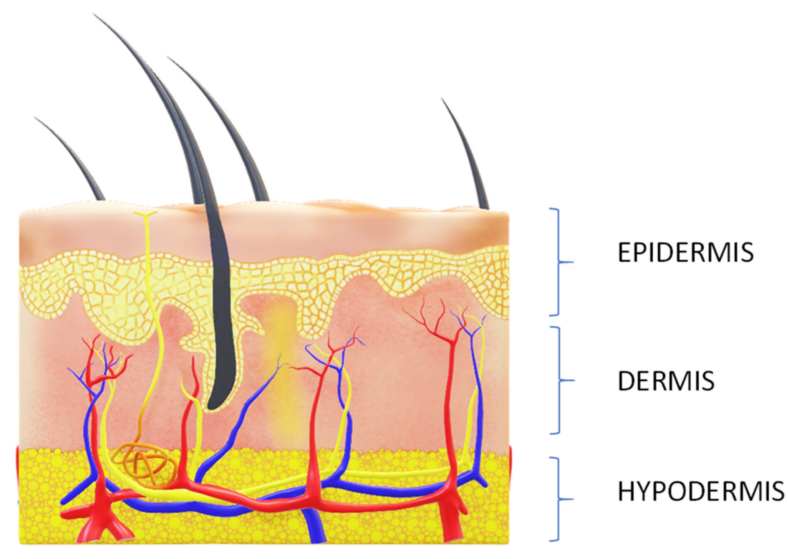

Figure 1. Diagram of the skin.

From the spinal cord, sensitive nervous or neuro-vegetative fibers innerve the skin [9], modulating thermoregulation, sebaceous secretion, or melanogenesis [4], explicating once again the definition of Misery "Les nerfs à fleur de peau" [9]. Indeed, many emotions are felt at the skin level: fear, stress, and happiness manifest themselves in paling (vasoconstriction), sweating, goosebumps, raised hairs, blushing (vasodilatation), or radiance [8].

The skin, as a system for the surveillance of environmental changes (heat, humidity, etc.) and perception of the environment (body limits, recognition of the non-self and objects, touch, etc.), produces stimuli that, through mediators, are transmitted to the nervous system [12,24]. For example, among mediators, there are neurotransmitters [24,25]; These are chemical messengers, naturally synthesized by nervous fiber endings, that are also produced by skin cells (keratinocytes, melanocytes, fibroblasts, etc.) and the immune system [11,12].

The release of neuromediators can be induced by physical, chemical, or even emotional stimuli [26]. Among the 200 neuromediators currently known, about 25 have been found in the skin. Some examples include neuropeptides such as substance $\mathrm{P}$, calcitonin generelated peptide (CGRP), and bradykinins; neurohormones such as melanocyte-stimulating hormone (MSH), and adrenocorticotropic hormone (ACTH); catecholamines; enkephalins; endorphins; and acetylcholine $[9,26]$. However, the neuromediators' level changes according to the person and their physiological or pathological circumstances $[9,26]$. Specific receptors for these neuromediators, and enzymes for degrading them, are expressed by cutaneous and immune cells. The binding of neurotransmitters to receptors induces the modulation of cell properties and skin functions (immunity, cell differentiation, proliferation, pigmentation, etc.). For example, substance $\mathrm{P}$ activates keratinocytes by increasing the synthesis of interleukin $1 \alpha$ and $\beta$, interleukin 8 , and tumor necrosis factor (TNF- $\alpha$ ), as well as intercellular adhesion molecule 1 (ICAM-1) expression on the keratinocyte surface $[9,26]$.

Hence, keratinocytes, Langerhans cells, melanocytes, endothelial cells, fibroblasts, and other skin or immune system cells are modulated and controlled by nerves. Reciprocally, the skin can modulate neuronal activity and growth. Nerve growth factors are slightly involved for this purpose, controlling both the neuronal growth and the neurotransmitters' secretion $[9,26]$. 
The result is that the skin is the window that connects the nervous, immune, cutaneous, and endocrine functions; it is important for maintaining physiological homeostasis [27].

As previously mentioned, the skin can interact with both endogenous and exogenous stimuli, and it is the target of nonmedical and medical treatments for healthy and diseased states.

This interesting connection, where the skin transmits and receives information from internal and external sources, induces the response of the neuroimmune-cutaneous-endocrine (NICE) system [5,9], and is useful for understanding neurocosmetics and the related brainskin connection for skincare.

\subsection{Neurocosmetics, the Cosmetic of Neurotransmitters: The Brain and Skincare}

After the definition of Misery in 2000 [10], neurocosmetics only began to receive great attention during the annual meeting of the New York Society of Cosmetic Chemists in 2007 [28]. To improve the skin's appearance and imperfections, neurocosmetic research was mainly focused on ingredients with structural analogies to endogenous neuromediators. Hence, when formulating neurocosmetics, considering that skin cells have receptors that bind neurotransmitters to regulate their functions, the knowledge of the connection mechanisms between the skin and the brain should be useful in choosing functional ingredients able to interact with both systems, obtaining specific results $[2,9,29]$.

For example, by targeting nerve clusters sensitive to heat, cold, pain, itching, and/or pressure, neurocosmetic products can affect the brain's responses to topical treatments. More specifically, the involved receptors send signals to the spinal cord that are subsequently transmitted to the cerebral cortex [2,12,28,30].

Neurocosmetic ingredients can act by following the mechanisms reported below:

- Directly on the cutaneous nervous fiber endings [9], as modulators of the neurotransmitter release [14]. Examples are the botulinum-like peptides that encourage facial musculature relaxation to obtain wrinkle-smoothing, and peptides that inhibit neurons, mainly used to make hypersensitive skin less reactive towards environmental stimuli (temperature changes, air humidity, smog, etc.) [9];

- They modulate non-nervous cells' functions as agonist/antagonist molecules of the neuropeptide receptors or neurotransmitter effects modulators $[9,14]$.

To clarify the concept of a neurocosmetic functional ingredient, a simple example is represented by menthol and its derivatives, which can act on the skin as a physical coolant or a heat source, according to the used formulations, area of application, and amount used [31-34].

However, over the years, a great number of functional ingredients-such as biomimetic peptides [35] deriving from different origins [36], and several plant extracts [37], able to perform neuro-modulatory actions-have been developed [38-40].

As a result, a new way to bring benefits to the skin's nervous system arises, which results in improved skin health, and the potential impact of this emerging field on skincare is significant [2]. Indeed, cosmetic manufacturers would treat the individual as a whole: the body and the mind.

However, it should be mentioned that neurocosmetics are largely used in anti-aging products. Therefore, neurocosmetic activities, by targeting the interactions between the skin and the nervous system, can play a significant role in skin balance [15,29].

In particular, neurocosmetics can render the skin smoother, more radiant, healthier, and less wrinkled, decreasing the inflammatory response and conferring a soothing effect.

For example, savvy brands try to overpass the traditional cosmetics limits, formulating skin solutions to fight stress and aging [2]. Thus, neurocosmetics seems to be the new cosmetic trend, but is everything really clear? Or are neurocosmetics manufacturers misleading with the idea that the use of some products-especially referring to makeup products-"induce" feelings of pleasantness and wellbeing? 


\subsubsection{Feelings of Pleasantness and Wellbeing vs. Neurocosmetics}

In most of the relevant online blogs, it is possible to read that the world of cosmetics is increasingly oriented towards a holistic vision of beauty, confusing the feelings of pleasantness and wellbeing derived from the application of a cosmetic product with a pleasant texture that induces hedonistic sensations, with neurocosmetics. The same occurs if a cosmetic is packaged in a particular way. A peculiar sensory experience, felt during the use of personal care products, can reduce life stress and, at the same time, persuade the consumers to buy a product from a specific brand. For example, when leave-on skincare products are taken into account, the sensory feel is an important aspect. Indeed, in this case, a sensory experience is offered to the consumers, which must not be confused with the neurocosmetic effects [41,42].

Moreover, cosmetic products described as euphoric or antidepressant are not uncommon. Several cosmetic companies proposed "happiness cosmetics", associating them, uncritically, with neurocosmetics, due to the presence of particular active ingredients in their formulation $[8,43]$. Some examples are reported in the following: Kenzoki Face Felicity Illuminating Serum, proposed by KENZO, induces the brightening of the facial skin using the white lotus extract in its formulation [44-48]. DEBORAH GROUP LABORATORIES developed the Gloss Euphoric Shine, a lipstick with a mix of components "that gives an immediate feeling of wellbeing" due to the presence of the nourishing and moisturizing blue poppy extract, omega- 6 and -9 , vitamins, and the innovative molecule Euphoryl ${ }^{\mathrm{TM}}$ $\Omega 3$ [49]. This active ingredient is a mix of Sacha inchi oil-rich in omega-3 [50-52]-and Schinus terebinthifolia (pink pepper) extract $[37,53]$. Omega-3 fatty acids help to counteract hypersensitivity, dryness, and inflammation, refining skin appearance, and also have antioxidant properties, thereby helping keep women's skin healthy and glowing. Euphoryl ${ }^{\mathrm{TM}}$ encourages dopamine synthesis at the skin level, allowing the lightening of the complexion. Furthermore, subjective studies have shown that it improves skin hydration, freshness, and comfort, which is significantly perceived by consumers [54]. However, the claims reported for this product could be misunderstood by consumers, erroneously making it appear to be a neurocosmetic.

So, the concepts of neurocosmetics, "good mood" cosmetics, and neurosciences are often discussed without drawing attention to their substantial differences, rendering the concepts unclear for both consumers and cosmetic experts as a consequence [55].

Although, for years, the fascinating and complex interconnection between the skin and the brain has drawn strong interest among cosmetic companies for its potential, the topic is very intricate, and it is perceived as confusing and fragmented [5,26,56,57].

Indeed, since the molecules synthesized at the brain level (brain, cerebellum, and brain stem) are the same as those used by the cutaneous nervous system for cell communication, an ability to regulate complex phenomena, such as mood, has been wrongly attributed to neurocosmetics.

This tendency to confer neurocosmetic functions to non-neurocosmetic ingredients could be called "neurocosmetics-fiction" [11]. This is so far from the correct definition of neurocosmetics that it can be better clarified considering the examples of Schinus terebinthifolia extract and Sacha inchi oil (Euphoryl ${ }^{\mathrm{TM}} \mathrm{O} 3$ ) activity to explain the role of a functional neurocosmetic ingredient. Firstly, it should be taken into account that many neurotransmitters and neurohormones, typically produced and released by the nervous system (serotonin, dopamine, endorphins, etc.), can also be produced and released in loco by specific skin cells, acting with different local functions. In this particular case, it has been widely demonstrated that, when applied to the skin, the Schinus terebinthifolia and Sacha inchi extracts can increase the release of dopamine by skin neurons, leading to two effects: the enhancement of skin blood supply and the skin barrier performance, and a global improvement of the complexion [58-60].

However, it must be highlighted that these effects differ from those observed when dopamine is produced at the central nervous system level, where dopamine plays the role of a neurotransmitter involved in brain network complexes associated with pleasure, 
satisfaction, and good mood [61]. Thus, the aforementioned neurocosmetics must not be considered to be "products" able to act on mood and happiness; attributes such as "antidepressant", "happiness", "euphoric", and "exhilarating" have been mistakenly conferred to products containing these extracts, going towards the pharmacological (and psychiatric) spheres, different from neurocosmetics. Indeed, only if the release of cutaneous dopamine is massive should it penetrate the blood, reaching the brain, but this is a not a probable scientific hypothesis for a cosmetic product that, by definition, must not penetrate the skin, and should remain on the epidermis [11].

Unfortunately, marketing uses these inaccurate concepts to attribute false claims to some cosmetic products - particularly belonging to the makeup category; this type of claim has led to poor market outcomes, inducing discomfort and fear in consumers [11].

In conclusion, neurocosmetics must not be confused with psychocosmetics or neurosciences, as better detailed in the following two paragraphs.

\section{Psychocosmetics}

With respect to neurocosmetics, the concept of psychocosmetics is intrinsically correlated with the concept of cosmetics itself. Indeed, cosmetic products help one to have a positive perception of oneself (self-esteem); therefore, cosmetics are promoters of wellbeing, enabling the relationships and conditions necessary to obtain gratification [62].

So, although cosmetics, by definition, are not considered to be drugs, they have a fundamental role in promoting health due to their ability to improve the individual's mental and social wellbeing, mood, and quality of life [60,63].

As a consequence, all cosmetics can be considered to be psychocosmetics, from deodorants, skin moisturizers, makeup, detergents, etc., to oncological aesthetics, which is defined as the noble cosmetics branch that helps women to take care of their image, especially if altered by anticancer therapies [11].

\section{Neurosciences}

Neurosciences, with respect to neurocosmetics, are devoted to the study of the nervous system. As reported by Lombardi et al. (2019), there are different branches of neuroscience, depending on the research studies, methods, and tools. Some examples are:

- Cellular Neurosciences study the behavior of nervous cells in vitro; these related experiments are usually performed by manufacturing companies on neurocosmetic functional ingredients;

- Behavioral Neurosciences study the cognitive (thoughts, memories, and other mental processes) and affective (emotions, feelings, and mood) behavior of individuals [11].

\section{Neuroscience Applications in the Cosmetic Field}

In recent years, neuroscience and psychological research have become an important topic both for marketing strategies and for research linked to consumers [55,62].

Not surprisingly, experts in neurology, psychology, and neuroscience have demonstrated that emotions, and the unconscious connection between consumers and products, could strongly affect the consumers' choices for purchasing cosmetics; hence, these studies can provide additional information for innovative products [60].

Niedziela reported that a cosmetic product seen on the shelf is an example of applied consumer neuroscience: it creates an immediate and strong impression on the consumer [41] and, in this case, it is important to understand how the product labeling and packaging affect the consumer's perceptions. Emotions play a significant role in the decision-making process, mixing the unconscious and conscious aspects of the experience. As a result, the addition of emotional profiling to the traditional and sensory profiling has added a new dimension during product development [41].

To create more appealing packaging designs, the psycho-behavioral approach and the traditional market research, neuroscientific, and psychological methodologies could be 
combined for understanding not only consumer expectations (brand perceptions), but also unconscious interactions with consumer products [41].

For example, the action readiness (whether the product is used or purchased) and autonomic stimulation (which reflects the degree of motor preparation for a certain action) are typically evaluated with physiological measures of the autonomic nervous system (ANS), where different aspects of the products are evaluated, and each type of evaluation is associated with specific physiological, expressive, or motivational changes [41].

Among methodologies, it is worth mentioning a range of technologies, from biometricssuch as heart rate variability (HR), galvanic skin response (GSR), facial electromyography (fEMG), etc.- - to brain imaging, such as functional magnetic resonance imaging (fMRI).

Biological, psychological, and ethological data can also be collected and analyzed by using different methods:

- Vital parameters such as heart activity recorded with ECG [64], respiratory activity/frequency, salivary samples for monitoring cortisol release [65,66] (i.e., the decrease in cortisol secretion in saliva after the use of a soothing cream should be observed) [56,67], thermography related to cutaneous blood flow (i.e., when blushing, etc.), the evolution of facial skin temperature under stress [64], and the electrical current perception threshold (CPT); the hyperexcitability of nerve endings $(\mathrm{A} \beta)$ increases with age, in which a threshold increase indicates a reduction of unpleasant excitability, (i.e., an improved state of wellness ... ) [64];

- Psychometric tests (perceived stress), such as the Ethological Coding System for Interviews (ECSI) (non-verbal behavior) [68,69]. Furthermore, using questionnaires, the effects (the hedonic pleasure of products) and appraisal (good/bad or pleasant/unpleasant) can be evaluated.

For cosmetic products, texture is also strongly involved in customer loyalty, so the emotional effects of tactile stimulation could be one of the keys to creating successful products. By means of neuroscientific instruments and methodologies, Lombardi et al. (2017) demonstrated in their study that three lip balms, containing the same ingredientsdifferent for only one emollient-could trigger different emotional responses during their application to the lips [70]. In detail, "lip balm 1" contained Octyldodecyl PCA, "lip balm 2" contained octyldodecanol, and "lip balm 3" contained Lauryl PCA—all at the same concentration. Moreover, the products tested had the same appearance and aroma. The research demonstrated that the final results were associated only with the tactile properties of the stimulus. For this purpose, the Authors used simultaneous electroencephalography (EEG) and galvanic skin response (GSR) measurements throughout the whole experiment. EEG is a non-expensive, noninvasive, and passive technique that, by using electrodes placed on the scalp, records the electrical activity generated by neurons' synchronized activity. GSR is one of the most sensitive methods for emotional arousal-the phenomenon by which the skin temporarily becomes a better conductor of electricity. When a positive or a negative stimulus is emotionally arousing, it activates the autonomic nervous system, which triggers an increase in sweating, especially in the palms of the hands and in the fingers, as well as the soles of the feet. Both positive and negative stimuli can result in an increase in arousal, triggering GSR. GSR measurement cannot reveal emotional valence, but has to be integrated with other data sources in order to paint the full picture of emotion [55]. The obtained results showed that "lip balm 1" was the best appreciated product; conversely, "lip balm 3" was least preferred. Thus, the PCA esters used as emollients-Octyldodecyl PCA adopted for "lip balm 1", and Lauryl PCA for "lip balm 3"—-showed highly significant differences in their unconscious effects. The authors supposed that the different chemical structures-i.e., the length of the alcoholic part of the esters' aliphatic chains-had a different impact on peripheral receptors, such as tactile receptors and nociceptors, among others [55].

In this context, the recent work by Sgoifo et al. (2021) indicates how a cosmetic routine can also be considered to be a way of helping stress resilience. In particular, the study suggests that a good strategy for fighting stress, obtaining long-lasting physio- 
logical, neuroendocrine, and psychological effects, could be the self-administration of a cosmetic product with a pleasant texture, rich in essential oils, and applied with a mindful massage [60].

\section{Neurocosmetic Ingredients}

Neurocosmetic functional ingredients can be formulated in different cosmetic forms targeted for every consumer's skin type and age. Some of the marketed neurocosmetic ingredients are thus discussed in the following section, focusing on anti-aging skincare ingredients, and to better understand their mechanisms of action, a brief insight into the affected biological pathways will also be presented.

In detail, the functional neurocosmetic ingredients for fighting skin aging will be presented, starting from neurocosmetics indicated for use against skin stress manifestations, followed by neurocosmetic ingredients specifically suitable for sensitive skin types. Finally, Botox-like peptides or plant extracts are also explored. The principal functional neurocosmetic ingredients used on the market are reported in Table 1, carefully detailing the related features useful for their use. 
Table 1. Neurocosmetic ingredients on the market ${ }^{1}$.

\begin{tabular}{|c|c|c|c|c|c|c|c|c|c|}
\hline $\begin{array}{l}\text { Company/ } \\
\text { Supplier }\end{array}$ & Product & $\begin{array}{c}\text { Functionality } \\
\text { Category }\end{array}$ & INCI & In Vitro/Ex vivo & In Vivo & Preservatives & $\begin{array}{l}\text { Use } \\
\text { Level }\end{array}$ & $\begin{array}{l}\text { Formulation/ } \\
\text { Processing }\end{array}$ & Features \\
\hline \multicolumn{10}{|c|}{ Neurocosmetic ingredients for combating skin stress } \\
\hline Provital Group & Agascalm & Skin protection. & $\begin{array}{l}\text { Propanediol (and) glycerin } \\
\text { (and) Agastache mexicana } \\
\text { flower/leaf/stem extract. }\end{array}$ & $\begin{array}{l}\text { Inhibition and release of } \\
\text { chemokines (up to } 104 \% \\
\text { in vitro). Reduction of } \\
\text { the LKB protein } \\
\text { degradation preventing } \\
\text { the release of NF-kB, } \\
\text { responsible for the } \\
\text { transcription of } \\
\text { proinflammatory agents; } \\
\text { migration of the } \\
\text { transcription factor } \\
\text { NF- } \mathrm{B} \text { to the nucleus (up } \\
\text { to } 70 \% \text { in vitro). }\end{array}$ & $\begin{array}{c}\text { Skin redness } \\
\text { reduction }(-10 \%) ; \\
\text { vasodilation } \\
\text { decrease }(-30 \%) ; \\
\text { skin hydration } \\
\text { improvement } \\
(+6 \%), \text { TEWL } \\
(-13 \%) .\end{array}$ & None & $1-3 \%$ & $\begin{array}{c}\text { Liquid; } \\
\text { water-soluble. }\end{array}$ & $\begin{array}{l}\text { Vascular tonicity } \\
\text { improvement; } \\
\text { restoration of the } \\
\text { barrier function } \\
\text { for moisturized } \\
\text { skin; skin radiance } \\
\text { enhancement and } \\
\text { skin tone } \\
\text { improvement. } \\
\text { Suitable for } \\
\text { sensitive skin. }\end{array}$ \\
\hline Givaudan & Betaphroline & Body sculpting. & $\begin{array}{c}\text { Aqua/water (and) } \\
\text { butylene glycol (and) } \\
\text { Tephrosia purpurea seed } \\
\text { extract (and) } \\
\text { phenoxyethanol. }\end{array}$ & $\begin{array}{c}\text { Stimulation of } \\
\beta \text {-endorphin release; } \\
\text { adenylate cyclase } \\
\text { activation; G3PDH } \\
\text { inhibition; glycerol } \\
\text { release. }\end{array}$ & $\begin{array}{l}\text { Pain relief and } \\
\text { improvement in } \\
\text { the wellbeing of } \\
\text { stomatodynia } \\
\text { patients (oral } \\
\text { application) (10\%, } \\
\text { D30; panelists' } \\
\text { evaluation. }\end{array}$ & Phenoxyethanol & $2-8 \%$ & $\begin{array}{c}\text { Liquid; } \\
\text { water-soluble. }\end{array}$ & $\begin{array}{c}\text { Neurocosmetic } \\
\text { and body shaping }\end{array}$ \\
\hline $\begin{array}{c}\text { Mibelle } \\
\text { Biochemistry }\end{array}$ & Happybelle-PE & $\begin{array}{l}\text { Skin conditioning; } \\
\text { anti-aging; } \\
\text { antioxidant. }\end{array}$ & $\begin{array}{l}\text { Happybelle-PE (standard } \\
\text { version): lecithin (and) } \\
\text { Vitex agnus-castus extract } \\
\text { (and) glycerin (and) } \\
\text { ascorbyl tetraisopalmitate } \\
\text { (and) tocopherol (and) } \\
\text { olus oil/vegetable oil (and) } \\
\text { cyclodextrin (and) alcohol } \\
\text { (and) aqua / water. } \\
\text { Happybelle O (oil-soluble } \\
\text { version): Vitex } \\
\text { agnus-castus extract (and) } \\
\text { Helianthus annuus } \\
\text { (sunflower) seed oil. }\end{array}$ & $\begin{array}{l}\text { Stimulation of cell } \\
\text { activity; increase in type } \\
\text { I and III collagen } \\
\text { (in vitro). }\end{array}$ & $\begin{array}{l}\text { Increase in skin } \\
\text { hydration and } \\
\text { firmness; decrease } \\
\text { in wrinkle depth. }\end{array}$ & None & $1-2 \%$ & $\begin{array}{c}\text { Liquid; } \\
\text { water-soluble. }\end{array}$ & $\begin{array}{l}\text { Reduction of fine } \\
\text { wrinkles and } \\
\text { deeper lines; } \\
\text { stimulation of } \\
\text { collagen } \\
\text { production; } \\
\text { improvement in } \\
\text { skin radiance; } \\
\text { plumping and } \\
\text { lifting effects. }\end{array}$ \\
\hline
\end{tabular}


Table 1. Cont.

\begin{tabular}{|c|c|c|c|c|c|c|c|c|c|}
\hline $\begin{array}{l}\text { Company/ } \\
\text { Supplier }\end{array}$ & Product & $\begin{array}{c}\text { Functionality } \\
\text { Category }\end{array}$ & INCI & In Vitro/Ex vivo & In Vivo & Preservatives & $\begin{array}{c}\text { Use } \\
\text { Level }\end{array}$ & $\begin{array}{l}\text { Formulation/ } \\
\text { Processing }\end{array}$ & Features \\
\hline $\begin{array}{l}\text { Provital } \\
\text { Group }\end{array}$ & Happy Skin & $\begin{array}{l}\text { Anti-aging; } \\
\text { antioxidant. }\end{array}$ & $\begin{array}{c}\text { Glycerin (and) aqua/water, } \\
\text { (and) Rhodiola rosea root } \\
\text { extract (and) } \\
\text { phenoxyethanol (and) } \\
\text { potassium sorbate. } \\
\text { Liposoluble version: } \\
\text { Helianthus annuus } \\
\text { (sunflower) seed oil (and) } \\
\text { Rhodiola rosea root extract } \\
\text { (and) Rosmarinus } \\
\text { officinalis (rosemary) leaf } \\
\text { extract. }\end{array}$ & $\begin{array}{l}\text { Protection from } \\
\text { free-radical-induced } \\
\text { damage. }\end{array}$ & $\begin{array}{l}\text { Increase in } \\
\text { endorphin levels; } \\
\text { enhancement of } \\
\text { skin appearance. }\end{array}$ & $\begin{array}{l}\text { Phenoxyethanol } \\
\text { (and) potassium } \\
\text { sorbate. No } \\
\text { preservatives in } \\
\text { the liposoluble } \\
\text { version }\end{array}$ & $\begin{array}{r}0.2- \\
2.0 \%\end{array}$ & $\begin{array}{c}\text { Liquid; } \\
\text { water-soluble. }\end{array}$ & $\begin{array}{l}\text { Recommended to } \\
\text { formulate facial, } \\
\text { body, and hair } \\
\text { care products. }\end{array}$ \\
\hline Givaudan & Neurophroline & Skin protection. & $\begin{array}{c}\text { Aqua/water (and) } \\
\text { propanediol (and) } \\
\text { Tephrosia purpurea seed } \\
\text { extract. }\end{array}$ & $\begin{array}{c}\text { Inhibition of stress } \\
\text { hormone cortisol release; } \\
\text { stimulation of } \\
\beta \text {-endorphin production; } \\
\text { global activation of } \\
\text { antistress genes } \\
\text { (transcriptomic on } \\
\text { keratinocytes and } \\
\text { fibroblasts); activation of } \\
\text { antistress proteins HMOX1 } \\
\text { and NQO1 (proteomic on } \\
\text { keratinocytes and } \\
\text { fibroblasts); increase in } \\
\text { HMOX1 and NQO1 } \\
\text { expression in the } \\
\text { epidermis (ex vivo). }\end{array}$ & $\begin{array}{l}\text { Efficacy on } \\
\text { stressed (polluted } \\
\text { air) skin: skin } \\
\text { luminosity } \\
\text { improvement; } \\
\text { skin redness } \\
\text { reduction; } \\
\text { improvement of } \\
\text { global skin color } \\
\text { (when used at 2\%); } \\
\text { dark eye circle } \\
\text { reduction. }\end{array}$ & None & $0.1-2 \%$ & $\begin{array}{c}\text { Liquid; } \\
\text { water-soluble. }\end{array}$ & $\begin{array}{l}\text { Overall skin stress } \\
\text { control. }\end{array}$ \\
\hline
\end{tabular}


Table 1. Cont.

\begin{tabular}{|c|c|c|c|c|c|c|c|c|c|}
\hline $\begin{array}{l}\text { Company/ } \\
\text { Supplier }\end{array}$ & Product & $\begin{array}{c}\text { Functionality } \\
\text { Category }\end{array}$ & INCI & In Vitro/Ex vivo & In Vivo & Preservatives & $\begin{array}{c}\text { Use } \\
\text { Level }\end{array}$ & $\begin{array}{l}\text { Formulation/ } \\
\text { Processing }\end{array}$ & Features \\
\hline Seppic & Sepicalm S WP & $\begin{array}{l}\text { Protective agent; } \\
\text { soothing agent; } \\
\text { skin conditioning } \\
\text { agent; skin } \\
\text { moisturizing } \\
\text { agent; sensorial } \\
\text { modifier. }\end{array}$ & $\begin{array}{l}\text { Sodium cocoyl amino } \\
\text { acids (and) sarcosine (and) } \\
\text { potassium aspartate (and) } \\
\text { magnesium aspartate. }\end{array}$ & $\begin{array}{l}+48 \% \text { production of } \\
\text { B-endorphins; Targets the } \\
\text { key inflammation pathway } \\
\text { (NF-kB): }-32 \% \text { of } \\
\text { IL-6/- } 16 \% \text { of IL- } 8 ;-78 \% \\
\text { of free radical induction } \\
\text { (superoxide anion); }-80 \% \\
\text { elastase inhibition; }-100 \% \\
\text { hyaluronidase inhibition; } \\
\text {-80\% lipoxygenase } \\
\text { inhibition. }\end{array}$ & $\begin{array}{c}\text { Benefits on } \\
\text { volunteers: skin } \\
\text { water content is } \\
\text { increased for up to } \\
5 \mathrm{~h} \text { after } \\
\text { application } \\
(+15 \%) ;-7.4 \% \\
\text { redness after } \\
\text { mechanical } \\
\text { abrasion; }-25 \% \\
\text { redness after solar } \\
\text { erythema; }-46 \% \\
\text { stinging sensation } \\
\text { in } 10 \mathrm{~s} .\end{array}$ & None & $3 \%$ & $\begin{array}{c}\text { Liquid; } \\
\text { water-soluble. }\end{array}$ & $\begin{array}{l}\text { Increased skin } \\
\text { comfort for } \\
\text { sensitive skin; } \\
\text { suitable for } \\
\text { sensitive skin. }\end{array}$ \\
\hline Seppic & $\begin{array}{l}\text { Sepicalm VG } \\
\text { WP }\end{array}$ & $\begin{array}{l}\text { Skin lightening } \\
\text { agent; soothing } \\
\text { care agent. }\end{array}$ & $\begin{array}{l}\text { Sodium palmitoyl proline } \\
\text { (and) Nymphaea alba } \\
\text { flower extract. }\end{array}$ & $\begin{array}{l}\text { Double skin lightening } \\
\text { action: inhibition of } \\
\text { inflammatory } \\
\text { pigmentation induced by } \\
\text { cutaneous stress, and } \\
\text { modulation of gene } \\
\text { expression in the basal } \\
\text { pigmentation (MIC1, MITF, } \\
\text { tyrosinase) after } 16 \mathrm{~h} \text {. }\end{array}$ & $\begin{array}{c}\text { Benefits on } \\
\text { volunteers: } 90 \% \\
\text { lighter skin; } 91 \% \\
\text { more radiant; } 94 \% \\
\text { lighter spots; } 73 \% \\
\text { smaller spots. }\end{array}$ & None & $3 \%$ & $\begin{array}{l}\text { Liquid; } \\
\text { amphiphilic. }\end{array}$ & $\begin{array}{l}\text { Suitable for } \\
\text { sensitive skin. }\end{array}$ \\
\hline \multicolumn{10}{|c|}{ Neurocosmetic ingredients for sensitive skin } \\
\hline Rahn & Defensil SOFT & $\begin{array}{l}\text { Anti-aging; } \\
\text { anti-inflammation; } \\
\text { anti-redness; } \\
\text { antistress; } \\
\text { couperose; } \\
\text { soothing. }\end{array}$ & $\begin{array}{l}\text { Propanediol (and) } \\
\text { Albatrellus ovinus extract } \\
\text { (and) citric acid. }\end{array}$ & $\begin{array}{c}\text { Affinity to TRPV1 } \\
\text { (in vitro); Functionally } \\
\text { blocks the TRPV1 receptor } \\
\text { (in vitro); Neuron-driven } \\
\text { inflammation (in vitro) } \\
\text { counteraction. }\end{array}$ & $\begin{array}{l}\text { Reduction of skin } \\
\text { discomfort and } \\
\text { irritation; } \\
\text { protection from } \\
\text { heat stress and } \\
\text { soothing of } \\
\text { hyperalgesic skin; } \\
\text { prevention of } \\
\text { IR-induced barrier } \\
\text { damage (in vivo). }\end{array}$ & None & $1-3 \%$ & $\begin{array}{c}\text { Liquid; } \\
\text { water-soluble. } \\
\text { Processing: } \\
\text { incorporation at } \\
\text { temperatures }< \\
50^{\circ} \mathrm{C} \text {. }\end{array}$ & $\begin{array}{l}\text { Increase in the } \\
\text { overall tolerance } \\
\text { of the skin to } \\
\text { irritants; } \\
\text { prevention of the } \\
\text { sensitization of } \\
\text { TRPV1 receptors } \\
\text { by blocking } \\
\text { serotonin } \\
\text { receptors; } \\
\text { prevention of } \\
\text { IR-aging by } \\
\text { protecting from } \\
\text { IR-induced heat } \\
\text { stress. }\end{array}$ \\
\hline
\end{tabular}


Table 1. Cont.

\begin{tabular}{|c|c|c|c|c|c|c|c|c|c|}
\hline $\begin{array}{l}\text { Company/ } \\
\text { Supplier }\end{array}$ & Product & $\begin{array}{l}\text { Functionality } \\
\text { Category }\end{array}$ & INCI & In Vitro/Ex vivo & In Vivo & Preservatives & $\begin{array}{l}\text { Use } \\
\text { Level }\end{array}$ & $\begin{array}{l}\text { Formulation/ } \\
\text { Processing }\end{array}$ & Features \\
\hline Givaudan & Mariliance & Skin protection. & $\begin{array}{c}\text { Aqua/water (and) } \\
\text { propanediol (and) } \\
\text { Rhodosorus marinus } \\
\text { extract. }\end{array}$ & $\begin{array}{l}\text { Reduction of TRPV1 } \\
\text { expression; inhibition of } \\
\text { the expression of IL- } 1 \alpha \text {, } \\
\text { NRG, and NGF R, and } \\
\text { reduction of NGF } \\
\text { production; reduction of } \\
\text { IL- } 1 \alpha \text { synthesis; } \\
\text { penetration of Mariliance } \\
\text { in emulsion and validation } \\
\text { of the results observed } \\
\text { in vitro on IL-1 } \alpha \\
\text { production (ex vivo). }\end{array}$ & $\begin{array}{l}\text { Reduction of skin } \\
\text { sensitivity }(3 \%) \text {. }\end{array}$ & None & $1-3 \%$ & $\begin{array}{c}\text { Liquid; } \\
\text { water-soluble. } \\
\text { Processing: } \\
\text { incorporation at } \\
\text { the end of the } \\
\text { formulation under } \\
\text { stirring or } \\
\text { homogenization; } \\
\text { can be heated for a } \\
\text { short time }<80^{\circ} \mathrm{C} \text {. } \\
\text { pH usage range: } \\
2.0-10.0 .\end{array}$ & $\begin{array}{l}\text { Neuro-soother; } \\
\text { calming, } \\
\text { anti-tightening. }\end{array}$ \\
\hline $\begin{array}{l}\text { Lucas Meyer } \\
\text { Cosmetics }\end{array}$ & Neutrazen & Soothing agent. & $\begin{array}{l}\text { Water (and) butylene } \\
\text { glycol (and) dextran (and) } \\
\text { palmitoyl tripeptide- } 8 \text {. }\end{array}$ & $\begin{array}{l}\text { Biomimetic of } \\
\text { neuromediator (POMC) } \\
\text { :reduction of the } \\
\text { consequences of substance } \\
\text { P release; inhibition of the } \\
\text { release of IL-1-induced } \\
\text { IL-8 production (in vitro). }\end{array}$ & $\begin{array}{l}\text { Reduction of } \\
\text { sensitive skin } \\
\text { symptoms related } \\
\text { to cutaneous } \\
\text { neurogenic } \\
\text { inflammation. }\end{array}$ & None & $\begin{array}{c}0.3- \\
2.5 \%\end{array}$ & $\begin{array}{c}\text { Liquid; } \\
\text { water-soluble; } \\
\text { colorless; } \\
\text { pH usage range: } \\
5.2-7.2 .\end{array}$ & $\begin{array}{l}\text { Designed to } \\
\text { prevent and } \\
\text { reverse signs of } \\
\text { neurogenic } \\
\text { inflammation } \\
\text { (redness and } \\
\text { swelling); calms } \\
\text { and soothes } \\
\text { irritated skin } \\
\text { caused by UV, } \\
\text { immune reactions, } \\
\text { and mechanical } \\
\text { stress; helps to } \\
\text { maintain and } \\
\text { restore a normal } \\
\text { skin sensitivity } \\
\text { threshold; suitable } \\
\text { for sensitive and } \\
\text { intolerant skin. }\end{array}$ \\
\hline Givaudan & Ocaline PF & Skin protection. & $\begin{array}{c}\text { Maris aqua (and) } \\
\text { aqua/water (and) } \\
\text { Cucurbita pepo seed } \\
\text { extract (and) potassium } \\
\text { sorbate (and) } \\
\text { phenoxyethanol (and) } \\
\text { citric Acid. }\end{array}$ & $\begin{array}{l}\text { Inhibition of the mast cells } \\
\text { degranulation (ex vivo) } \\
\text { and histamine release } \\
\text { induced by substance P. }\end{array}$ & $\begin{array}{c}\text { Preventive effect } \\
\text { on sensitive } \\
\text { skin/stinging test } \\
\text { (5\%); soothing of } \\
\text { irritated skin (10\%, } \\
60 \text { min, } 180 \text { min, } \\
24 \text { h). }\end{array}$ & $\begin{array}{c}\text { Potassium sorbate } \\
\text { (and) } \\
\text { phenoxyethanol }\end{array}$ & $3-10 \%$ & $\begin{array}{c}\text { Liquid; } \\
\text { water-soluble. }\end{array}$ & $\begin{array}{l}\text { Prevention of } \\
\text { sensitive skin by a } \\
\text { neurocosmetic } \\
\text { approach. }\end{array}$ \\
\hline
\end{tabular}


Table 1. Cont.

\begin{tabular}{|c|c|c|c|c|c|c|c|c|c|}
\hline $\begin{array}{l}\text { Company/ } \\
\text { Supplier }\end{array}$ & Product & $\begin{array}{l}\text { Functionality } \\
\text { Category }\end{array}$ & INCI & In Vitro/Ex vivo & In Vivo & Preservatives & $\begin{array}{l}\text { Use } \\
\text { Level }\end{array}$ & $\begin{array}{l}\text { Formulation/ } \\
\text { Processing }\end{array}$ & Features \\
\hline Givaudan & Ocaline XP & Skin protection. & $\begin{array}{c}\text { Maris aqua (and) } \\
\text { aqua/water (and) } \\
\text { Cucurbita pepo seed } \\
\text { extract (and) citric acid } \\
\text { (and) benzyl } \\
\text { alcohol (and) potassium } \\
\text { sorbate. }\end{array}$ & $\begin{array}{l}\text { Inhibition of the mast cells' } \\
\text { degranulation (ex vivo). }\end{array}$ & $\begin{array}{c}\text { Preventive effect } \\
\text { on sensitive } \\
\text { skin/stinging test } \\
(5 \%) \text {; soothing of } \\
\text { irritated skin }(10 \% \text {, } \\
60 \mathrm{~min}, 180 \mathrm{~min}, \\
24 \mathrm{~h}) .\end{array}$ & $\begin{array}{l}\text { Benzyl alcohol } \\
\text { (and) potassium } \\
\text { sorbate }\end{array}$ & $3-10 \%$ & $\begin{array}{c}\text { Liquid; } \\
\text { water-soluble. }\end{array}$ & $\begin{array}{l}\text { Prevention of } \\
\text { sensitive skin by a } \\
\text { neurocosmetic } \\
\text { approach; soothes } \\
\text { away neurogenic } \\
\text { inflammation. }\end{array}$ \\
\hline $\begin{array}{c}\text { Mibelle } \\
\text { Biochemistry }\end{array}$ & Pinolumin & $\begin{array}{l}\text { Antioxidant; } \\
\text { energizing; } \\
\text { radiance; } \\
\text { anti-redness; } \\
\text { whitening. }\end{array}$ & $\begin{array}{l}\text { Standard version: Pinus } \\
\text { cembra wood extract (and) } \\
\text { alcohol (and) pentylene } \\
\text { glycol (and) aqua/ water; } \\
\text { Alcohol-free powder } \\
\text { version, twofold } \\
\text { concentrated: Pinus } \\
\text { cembra wood extract (and) } \\
\text { maltodextrin (and) } \\
\text { aqua/water. }\end{array}$ & $\begin{array}{c}\text { Inhibition of } \\
\text { neuroinflammation } \\
\text { (in vitro); inhibition of the } \\
\text { function of TRPV1 } \\
\text { (in vitro); } \\
\text { anti-inflammatory activity: } \\
\text { inhibition of the release of } \\
\text { proinflammatory } \\
\text { mediators (CGRP, IL-8, } \\
\text { and PGE2) (in vitro); } \\
\text { protection of collagen by } \\
\text { inhibiting the } \\
\text { UVA-induced MMP-1 } \\
\text { production (in vitro). }\end{array}$ & $\begin{array}{l}\text { Visible } \\
\text { anti-redness effect; } \\
\text { reduction of color } \\
\text { irregularities; } \\
\text { overall } \\
\text { improvement of } \\
\text { skin tone } \\
\text { evenness. }\end{array}$ & None & $2 \%$ & $\begin{array}{c}\text { Liquid; } \\
\text { water-soluble. } \\
\text { Incorporation: For } \\
\text { cold processes, } \\
\text { dissolve } \\
\text { Pinolumin into the } \\
\text { aqueous phase. In } \\
\text { hot/cold } \\
\text { processes, add } \\
\text { during the cooling } \\
\text { phase below } 40^{\circ} \mathrm{C} \text {. } \\
\text { Thermostability: } \\
\text { temperatures of } \\
\text { up to } 40^{\circ} \mathrm{C} \text { for a } \\
\text { short time will not } \\
\text { affect the stability } \\
\text { of Pinolumin. }\end{array}$ & $\begin{array}{l}\text { Calms sensitive } \\
\text { and irritated skin; } \\
\text { visibly reduces } \\
\text { redness and age } \\
\text { spots; protects } \\
\text { from the effects of } \\
\text { environmental } \\
\text { stress; } \\
\text { suitable for } \\
\text { sensitive skin. }\end{array}$ \\
\hline $\begin{array}{c}\text { Mibelle } \\
\text { Biochemistry }\end{array}$ & SensAmone P5 & Skin conditioning. & $\begin{array}{l}\text { Pentapeptide-59 (and) } \\
\text { hydrogenated lecithin } \\
\text { (and) Butyrospermum } \\
\text { parkii (shea) butter (and) } \\
\text { phenethyl alcohol (and) } \\
\text { ethylhexylglycerin (and) } \\
\text { maltodextrin (and) } \\
\text { aqua/water. }\end{array}$ & $\begin{array}{l}\text { Inhibition of TRPV1 } \\
\text { receptor activation } \\
\text { (in vitro). }\end{array}$ & $\begin{array}{l}\text { Instant reduction } \\
\text { of skin reactivity } \\
\text { following a single } \\
\text { application; } \\
\text { reduction of skin } \\
\text { sensitivity. }\end{array}$ & None & $1-2 \%$ & $\begin{array}{c}\text { Liquid; } \\
\text { water-soluble. }\end{array}$ & $\begin{array}{l}\text { Calms } \\
\text { over-reactive skin; } \\
\text { minimizes skin's } \\
\text { response to stress; } \\
\text { reduces the } \\
\text { itching sensation } \\
\text { of sensitive skin; } \\
\text { suitable for } \\
\text { sensitive skin. }\end{array}$ \\
\hline
\end{tabular}


Table 1. Cont.

\begin{tabular}{|c|c|c|c|c|c|c|c|c|c|}
\hline $\begin{array}{l}\text { Company/ } \\
\text { Supplier }\end{array}$ & Product & $\begin{array}{l}\text { Functionality } \\
\text { Category }\end{array}$ & INCI & In Vitro/Ex vivo & In Vivo & Preservatives & $\begin{array}{l}\text { Use } \\
\text { Level }\end{array}$ & $\begin{array}{l}\text { Formulation/ } \\
\text { Processing }\end{array}$ & Features \\
\hline Givaudan & Sensityl & Skin protection. & $\begin{array}{c}\text { Water (and) } \\
\text { Phaeodactylum } \\
\text { tricornutum extract (and) } \\
\text { pentylene glycol. }\end{array}$ & $\begin{array}{l}\text { Epigenetic control of } \\
\text { inflammation through } \\
\text { exosomal communication; } \\
\text { genetic control of skin } \\
\text { soothing and calming } \\
\text { (downregulation of a } \\
\text { complete set of genes } \\
\text { involved in } \\
\text { anti-inflammatory and } \\
\text { soothing activities); control } \\
\text { of the acute phase of } \\
\text { inflammation (reduction of } \\
\text { immune cell recruitment); } \\
\text { inhibition of immune cell } \\
\text { recruitment (significant } \\
\text { reduction of dendritic } \\
\text { cells) (ex vivo 3\%); } \\
\text { reduction of } \\
\text { proinflammatory signal } \\
\text { through IL-8 inhibition (ex } \\
\text { vivo 3\%); reduction of pain } \\
\text { sensation through TRPV1 } \\
\text { expression reduction (ex } \\
\text { vivo 3\%); control of } \\
\text { microbial proliferation (ex } \\
\text { vivo 3\%). }\end{array}$ & $\begin{array}{c}\text { Protection of skin } \\
\text { microbiota against } \\
\text { sensitive skin } \\
\text { conditions ( } 3 \% \text { vs. } \\
\text { placebo), } \\
\text { restoration and } \\
\text { protection of } \\
\text { sensitive skin }(3 \%) ; \\
\text { improvement of } \\
\text { cutaneous } \\
\text { reactivity }(3 \%) .\end{array}$ & $\begin{array}{l}\text { Sodium benzoate } \\
\text { (and) benzoic acid }\end{array}$ & $1-3 \%$ & $\begin{array}{c}\text { Liquid; } \\
\text { water-soluble. }\end{array}$ & $\begin{array}{l}\text { Soothing; calming; } \\
\text { neuro-soothing; } \\
\text { skin microflora } \\
\text { rebalancing. }\end{array}$ \\
\hline BASF & $\begin{array}{c}\text { Skinasensyl LS } \\
9749\end{array}$ & Soothing agent. & $\begin{array}{l}\text { Liquid synthetic } \\
\text { tetrapeptide: water (and) } \\
\text { glycerin (and) } \\
\text { coco-glucoside (and) acetyl } \\
\text { tetrapeptide-15. }\end{array}$ & $\begin{array}{l}\text { Binding on the } \mu \text {-opioid } \\
\text { receptor (in vitro); } \\
\text { inhibition of the CGRP } \\
\text { release by sensory neurons } \\
\text { (in vitro). }\end{array}$ & $\begin{array}{l}\text { Increase of the } \\
\text { skin's tolerance } \\
\text { threshold. }\end{array}$ & Sorbic acid & $1-3 \%$ & $\begin{array}{c}\text { Liquid; } \\
\text { water-soluble. } \\
\text { Processing: it is } \\
\text { incorporated into } \\
\text { the finishing } \\
\text { process below } 50 \\
{ }^{\circ} \mathrm{C} \text {, or at room } \\
\text { temperature for } \\
\text { cold processing; } \\
\text { colorless. }\end{array}$ & $\begin{array}{l}\text { Inhibits the release } \\
\text { of the CGRP } \\
\text { neuromediator } \\
\text { from sensory } \\
\text { neurons; increases } \\
\text { the skin tolerance } \\
\text { threshold; } \\
\text { specifically } \\
\text { designed to soothe } \\
\text { sensitive skin. }\end{array}$ \\
\hline
\end{tabular}


Table 1. Cont.

\begin{tabular}{|c|c|c|c|c|c|c|c|c|c|}
\hline $\begin{array}{l}\text { Company/ } \\
\text { Supplier }\end{array}$ & Product & $\begin{array}{c}\text { Functionality } \\
\text { Category }\end{array}$ & INCI & In Vitro/Ex vivo & In Vivo & Preservatives & $\begin{array}{l}\text { Use } \\
\text { Level }\end{array}$ & $\begin{array}{l}\text { Formulation/ } \\
\text { Processing }\end{array}$ & Features \\
\hline BASF & $\begin{array}{c}\text { Skinasensyl LS } \\
9852\end{array}$ & Soothing agent. & $\begin{array}{l}\text { Powder synthetic } \\
\text { tetrapeptide: mannitol } \\
\text { (and) sodium citrate (and) } \\
\text { acetyl tetrapeptide- } 15 .\end{array}$ & $\begin{array}{l}\text { Binding on the } \mu \text {-opioid } \\
\text { receptor (in vitro); } \\
\text { inhibition of CGRP release } \\
\text { by sensory neurons } \\
\text { (in vitro). }\end{array}$ & $\begin{array}{l}\text { Increase of the } \\
\text { skin's tolerance } \\
\text { threshold } \\
\text { (capsaicin, heat) } \\
\text { (in vivo). }\end{array}$ & None & $\begin{array}{c}0.3- \\
1.0 \%\end{array}$ & $\begin{array}{l}\text { Powder; } \\
\text { water-soluble; } \\
\text { colorless. }\end{array}$ & $\begin{array}{c}\text { Inhibits the release } \\
\text { of the } \\
\text { neuromediator } \\
\text { CGRP from } \\
\text { sensory neurons; } \\
\text { increases the skin } \\
\text { tolerance } \\
\text { threshold; } \\
\text { specifically } \\
\text { designed to soothe } \\
\text { sensitive skin. }\end{array}$ \\
\hline Seppic & Sepicalm S WP & $\begin{array}{c}\text { Protective agent; } \\
\text { soothing agent; } \\
\text { skin conditioning } \\
\text { agent; skin } \\
\text { moisturizing } \\
\text { agent; sensorial } \\
\text { modifier. }\end{array}$ & $\begin{array}{l}\text { Sodium cocoyl amino } \\
\text { acids (and) sarcosine (and) } \\
\text { potassium aspartate (and) } \\
\text { magnesium aspartate. }\end{array}$ & $\begin{array}{l}+48 \% \text { production of } \\
\text { B-endorphins; Targets the } \\
\text { key inflammation pathway } \\
\text { (NF-kB): }-32 \% \text { of } \\
\text { IL-6/-16\% of IL- } 8 ;-78 \% \\
\text { of free radical induction } \\
\text { (superoxide anion); }-80 \% \\
\text { elastase inhibition; }-100 \% \\
\text { hyaluronidase inhibition; } \\
-80 \% \text { lipoxygenase } \\
\text { inhibition. }\end{array}$ & $\begin{array}{c}\text { Benefits on } \\
\text { volunteers: skin } \\
\text { water content is } \\
\text { increased for up to } \\
5 \mathrm{~h} \text { after } \\
\text { application } \\
(+15 \%) ;-7.4 \% \\
\text { redness after } \\
\text { mechanical } \\
\text { abrasion; }-25 \% \\
\text { redness after solar } \\
\text { erythema; }-46 \% \\
\text { stinging sensation } \\
\text { in } 10 \mathrm{~s} \text {. }\end{array}$ & None & $3 \%$ & $\begin{array}{c}\text { Liquid; } \\
\text { water-soluble. }\end{array}$ & $\begin{array}{l}\text { Increase skin } \\
\text { comfort for } \\
\text { sensitive skin; } \\
\text { suitable for } \\
\text { sensitive skin. }\end{array}$ \\
\hline Seppic & $\begin{array}{c}\text { Sepicalm VG } \\
\text { WP }\end{array}$ & $\begin{array}{l}\text { Skin lightening } \\
\text { agent; soothing } \\
\text { care agent. }\end{array}$ & $\begin{array}{l}\text { Sodium palmitoyl proline } \\
\text { (and) Nymphaea alba } \\
\text { flower extract }\end{array}$ & $\begin{array}{l}\text { Double skin lightening } \\
\text { action: inhibition of } \\
\text { inflammatory } \\
\text { pigmentation induced by } \\
\text { cutaneous stress, and } \\
\text { modulation of gene } \\
\text { expression in the basal } \\
\text { pigmentation (MIC1, MITF, } \\
\text { tyrosinase) after } 16 \mathrm{~h} \text {. }\end{array}$ & $\begin{array}{c}\text { Benefits on } \\
\text { volunteers: } 90 \% \\
\text { lighter skin, } 91 \% \\
\text { more radiant, } 94 \% \\
\text { lighter spots, } 73 \% \\
\text { smaller spots. }\end{array}$ & None & $3 \%$ & $\begin{array}{c}\text { Liquid; } \\
\text { Amphiphilic }\end{array}$ & $\begin{array}{c}\text { Suitable for } \\
\text { sensitive skin }\end{array}$ \\
\hline
\end{tabular}


Table 1. Cont.

\begin{tabular}{|c|c|c|c|c|c|c|c|c|c|}
\hline $\begin{array}{l}\text { Company/ } \\
\text { Supplier }\end{array}$ & Product & $\begin{array}{l}\text { Functionality } \\
\text { Category }\end{array}$ & INCI & In Vitro/Ex vivo & In Vivo & Preservatives & $\begin{array}{c}\text { Use } \\
\text { Level }\end{array}$ & $\begin{array}{l}\text { Formulation/ } \\
\text { Processing }\end{array}$ & Features \\
\hline \multicolumn{10}{|c|}{ "Coolant" neurocosmetic ingredients for sensitive skin } \\
\hline Givaudan & $\begin{array}{l}\text { Evercool } \\
\text { Skin }\end{array}$ & Cooling. & $\begin{array}{l}\text { Menthyl PCA (and) } \\
\text { Lactamide MEA (and) } \\
\text { menthane carboxamide } \\
\text { ethylpyridine. }\end{array}$ & $\begin{array}{c}\text { Activation of cooling } \\
\text { sensation receptor TRMP8. }\end{array}$ & $\begin{array}{l}\text { Long-lasting } \\
\text { cooling effect ( } 2 \% \text {, } \\
30 \mathrm{~min}, 60 \mathrm{~min}, \\
120 \mathrm{~min}) .\end{array}$ & None & $1-4 \%$ & $\begin{array}{c}\text { Water-soluble; } \\
\text { soluble in alcohol; } \\
\text { odorless. }\end{array}$ & $\begin{array}{c}\text { Patented } \\
\text { combination of } \\
\text { Givaudan cooling } \\
\text { activities; } \\
\text { improved, } \\
\text { long-lasting } \\
\text { freshness. } \\
\end{array}$ \\
\hline Salvona & $\begin{array}{l}\text { HydroSal } \\
\text { SalCool }\end{array}$ & $\begin{array}{l}\text { Cooling; delivery } \\
\text { systems/carriers. }\end{array}$ & $\begin{array}{l}\text { Propylene glycol (and) } \\
\text { hydroxypropyl Cellulose } \\
\text { (and) methyl diisopropyl } \\
\text { propionamide (and) } \\
\text { menthyl lactate (and) ethyl } \\
\text { menthane carboxamide } \\
\text { (and) phenethyl alcohol } \\
\text { (and) caprylyl glycol (and) } \\
\text { ethylhexylglycerin. }\end{array}$ & $\begin{array}{l}\text { The release kinetics of the } \\
\text { ingredients are optimized } \\
\text { and synchronized to result } \\
\text { in continuous, long-lasting, } \\
\text { enhanced refreshment. }\end{array}$ & $\begin{array}{c}\text { In a consumer } \\
\text { perception test, } \\
\text { the intensity of the } \\
\text { sensation from an } \\
\text { aftershave balm } \\
\text { containing } \\
\text { HydroSalTM } \\
\text { SalCool was } \\
\text { compared to an } \\
\text { aftershave } \\
\text { balm containing } \\
\text { free } \\
\text { menthol at } 1 \% \\
\text { loading: } \\
\text { HydroSal' } \\
\text { SalCool lasted } \\
\text { twice as long as } \\
\text { the freementhol at } \\
\text { the same strength. }\end{array}$ & None & $\begin{array}{c}7.0- \\
15.0 \%\end{array}$ & $\begin{array}{l}\text { Water-soluble; } \\
\text { compatible with } \\
\text { hydro-alcoholic } \\
\text { formulations; } \\
\text { odorless. } \\
\text { Processing: } \\
\text { incorporation to } \\
\text { the water phase } \\
\text { during production, } \\
\text { or at the end of the } \\
\text { process when the } \\
\text { temperature is } \\
\text { below } 30^{\circ} \mathrm{C} \text {. }\end{array}$ & $\begin{array}{l}\text { Suitable for } \\
\text { sensitive skin; it } \\
\text { can be } \\
\text { incorporated in } \\
\text { skin, lip, scalp, } \\
\text { and hair care } \\
\text { formulations. }\end{array}$ \\
\hline \multicolumn{10}{|c|}{ Neurocosmetic ingredients for skin aging } \\
\hline $\begin{array}{l}\text { Lucas Meyer } \\
\text { Cosmetics }\end{array}$ & Adipofill'in & $\begin{array}{c}\text { Anti-aging; } \\
\text { anti-wrinkle; skin } \\
\text { conditioning; } \\
\text { delivery systems / } \\
\text { carriers. }\end{array}$ & $\begin{array}{l}\text { Aqua/water (and) } \\
\text { propanediol (and) } \\
\text { ornithine (and) } \\
\text { phospholipids (and) } \\
\text { glycolipids. }\end{array}$ & $\begin{array}{c}\text { Activation of HIF-1 } \alpha ; \\
\text { increase in lipid storage in } \\
\text { human adipocytes; } \\
\text { decrease in fatty acids } \\
\text { released } \\
\text { from adipocytes. }\end{array}$ & $\begin{array}{l}\text { Lipofilling-like } \\
\text { effect; decrease in } \\
\text { nasogenian fold } \\
\text { depth and skin } \\
\text { roughness. }\end{array}$ & None & $0.5-2 \%$ & $\begin{array}{c}\text { Liquid; } \\
\text { water-soluble; } \\
\text { pH usage range: } \\
\text { 4.5-6.0. Incorpora- } \\
\text { tion/processing: } \\
\text { at the end of the } \\
\text { formulation }(<40 \\
\left.{ }^{\circ} \mathrm{C}\right) .\end{array}$ & $\begin{array}{l}\text { Skin smoother, } \\
\text { firmer, less tired, } \\
\text { plumper } \\
\text { and lifted; } \\
\text { reduction of } \\
\text { nasogenian folds. }\end{array}$ \\
\hline
\end{tabular}


Table 1. Cont.

\begin{tabular}{|c|c|c|c|c|c|c|c|c|c|}
\hline $\begin{array}{l}\text { Company/ } \\
\text { Supplier }\end{array}$ & Product & $\begin{array}{l}\text { Functionality } \\
\text { Category }\end{array}$ & INCI & In Vitro/Ex vivo & In Vivo & Preservatives & $\begin{array}{l}\text { Use } \\
\text { Level }\end{array}$ & $\begin{array}{l}\text { Formulation/ } \\
\text { Processing }\end{array}$ & Features \\
\hline $\begin{array}{c}\text { Biosil } \\
\text { Technologies }\end{array}$ & Glistin & $\begin{array}{l}\text { Anti-aging; } \\
\text { antioxidant }\end{array}$ & $\begin{array}{l}\text { Glutamylamidoethyl } \\
\text { indole (and) aqua/water }\end{array}$ & $\begin{array}{l}\text { Neurotrophic effect } \\
\text { (NGF-like); } \\
\text { neuro-cutaneous } \\
\text { messenger; cutaneous } \\
\text { neuroprotection: } \\
\text { anti-apoptotic effect. }\end{array}$ & $\begin{array}{l}\text { «Antistress» } \\
\text { (cutaneous } \\
\text { sensitivity). }\end{array}$ & None & $1 \%$ & $\begin{array}{c}\text { Liquid; } \\
\text { water-soluble; } \\
\text { miscible with } \\
\text { alcohols and } \\
\text { glycols; colorless; } \\
\text { pH usage range: } \\
7.0 .\end{array}$ & $\begin{array}{l}\text { Prevention of neu- } \\
\text { rodegeneration. }\end{array}$ \\
\hline $\begin{array}{c}\text { Biosil } \\
\text { Technologies }\end{array}$ & Glutrapeptide & $\begin{array}{l}\text { Slimming and } \\
\text { firming agent; } \\
\text { anti-aging; } \\
\text { antioxidant. }\end{array}$ & $\begin{array}{l}\text { Pyroglutamylamidoethyl } \\
\text { indole (and) butylene } \\
\text { glycol. }\end{array}$ & $\begin{array}{l}\text { Enhancement of neurons' } \\
\text { ability to support lipolysis; } \\
\text { synergy with caffeine for } \\
\text { slimming effect; } \\
\text { enhancement of fibroblast } \\
\text { contractile ability together } \\
\text { with NGF. }\end{array}$ & $\begin{array}{c}\text { Skin appearance, } \\
\text { firmness, density, } \\
\text { and elasticity } \\
\text { improvement after } \\
28 \text { days of } \\
\text { treatment; } \\
\text { amelioration of } \\
\text { cellulite } \\
\text { appearance after } \\
28 \text { days of } \\
\text { treatment; overall } \\
\text { slimming effect up } \\
\text { to } 4 \mathrm{~cm} \text { for the } \\
\text { arms, } 6 \mathrm{~cm} \text { for the } \\
\text { waist, } 4 \mathrm{~cm} \text { for the } \\
\text { abdomen, and } 3.5 \\
\mathrm{~cm} \text { for the thighs. }\end{array}$ & None & $1-5 \%$ & $\begin{array}{c}\text { Liquid; } \\
\text { water-soluble; } \\
\text { colorless; } \\
\text { pH usage range: } \\
6.0 ; \\
\text { miscible with } \\
\text { alcohols and } \\
\text { glycols. }\end{array}$ & $\begin{array}{l}\text { Neuroprotection; } \\
\text { neuroslimming; } \\
\text { body firming; cell } \\
\text { detoxification; } \\
\text { prevention of neu- } \\
\text { rodegeneration. }\end{array}$ \\
\hline $\begin{array}{l}\text { Codif } \\
\text { Technologie } \\
\text { Naturelle }\end{array}$ & Lakesis & $\begin{array}{l}\text { Anti-aging; } \\
\text { firming. }\end{array}$ & $\begin{array}{c}\text { Caprylic/capric } \\
\text { triglyceride (and) Pistacia } \\
\text { lentiscus (mastic) gum. }\end{array}$ & $\begin{array}{l}\text { Activation of youth } \\
\text { proteins KLOTHO and } \\
\text { FOXO; reactivation of } \\
\text { cellular detoxification } \\
\text { processes; improvement of } \\
\text { cellular activity; } \\
\text { improvement of type I } \\
\text { collagen synthesis by } 47 \% \text {; } \\
\text { reactivation of fibrillin } \\
\text { synthesis. }\end{array}$ & $\begin{array}{l}\text { Redensification of } \\
\text { the dermis; } \\
\text { improvement of } \\
\text { facial contours. }\end{array}$ & None & $0.2 \%$ & $\begin{array}{c}\text { Liquid; } \\
\text { liposoluble. } \\
\text { Processing: stable } \\
\text { up to } 80^{\circ} \mathrm{C} \text {. }\end{array}$ & $\begin{array}{l}\text { Lifting action on } \\
\text { the oval face. }\end{array}$ \\
\hline
\end{tabular}


Table 1. Cont.

\begin{tabular}{|c|c|c|c|c|c|c|c|c|c|}
\hline $\begin{array}{l}\text { Company/ } \\
\text { Supplier }\end{array}$ & Product & $\begin{array}{c}\text { Functionality } \\
\text { Category }\end{array}$ & INCI & In Vitro/Ex vivo & In Vivo & Preservatives & Use Level & $\begin{array}{l}\text { Formulation/ } \\
\text { Processing }\end{array}$ & Features \\
\hline BASF & Neurobiox & $\begin{array}{c}\text { Anti-wrinkle; } \\
\text { anti-aging; } \\
\text { brightening agent. }\end{array}$ & $\begin{array}{l}\text { Water (and) butylene } \\
\text { glycol (and) pentylene } \\
\text { glycol (and) Achillea } \\
\text { millefolium extract (and) } \\
\text { xanthan gum. }\end{array}$ & $\begin{array}{l}\text { Improvement of the } \\
\text { epidermal thickness (ex } \\
\text { vivo); stimulation of } \\
\text { epidermal differentiation } \\
\text { (ex vivo); stimulation of } \\
\text { synthesis: filaggrin, } \\
\text { cytokeratin 10, MO-R1, } \\
\text { and MC-2R receptors (ex } \\
\text { vivo); dose-effect on the } \\
\text { gene expression of MC-2R } \\
\text { and MOR-1 receptors; } \\
\text { effect on the protein } \\
\text { synthesis of MC-2R and } \\
\text { MOR-1; Stimulation of } \\
\text { involucrin gene expression } \\
\text { (in vitro). }\end{array}$ & $\begin{array}{l}\text { Pore refining; skin } \\
\text { brightening; skin } \\
\text { softness; } \\
\text { stimulation of } \\
\text { epidermal } \\
\text { renewal; wrinkle } \\
\text { smoothening. }\end{array}$ & None & $0.5-2 \%$ & $\begin{array}{l}\text { Liquid; } \\
\text { water-soluble; } \\
\text { colorless; low-pH } \\
\text { tolerant; high-pH } \\
\text { tolerant; cation } \\
\text { compatible. }\end{array}$ & $\begin{array}{l}\text { Support of cell } \\
\text { communication by } \\
\text { stimulating the } \\
\text { expression of } \\
\text { POMC-related } \\
\text { receptors; } \\
\text { improvement of } \\
\text { epidermal } \\
\text { differentiation; } \\
\text { acceleration of } \\
\text { skin renewal; } \\
\text { improvement of } \\
\text { skin softness, } \\
\text { radiance, and } \\
\text { visible reduction } \\
\text { of the appearance } \\
\text { of wrinkles and } \\
\text { pores. }\end{array}$ \\
\hline $\begin{array}{l}\text { Codif } \\
\text { Technologie } \\
\text { Naturelle }\end{array}$ & Neuroguard & $\begin{array}{l}\text { Anti-aging; } \\
\text { anti-wrinkle. }\end{array}$ & $\begin{array}{c}\text { Glycerin (and) } \\
\text { aqua/water (and) } \\
\text { hydrolyzed algin }\end{array}$ & $\begin{array}{l}\text { Increase in the production } \\
\text { of neuroprotector sAPP } \alpha \\
\text { by } 87 \% \text { (in vitro); protects } \\
\text { the communication } \\
\text { between nerves and } \\
\text { fibroblasts from the } \\
\text { toxicity of neuro-aging and } \\
\text { preserves fibroblasts' } \\
\text { activity (in vitro); } \\
\text { protection of the } \\
\text { extracellular matrix from } \\
\text { the toxicity of neuro-aging } \\
\text { (in vitro); protection of the } \\
\text { synthesis of collagen and } \\
\text { elastin from neuro-aging } \\
\text { toxicity (in vitro). }\end{array}$ & $\begin{array}{l}\text { Reduce the } \\
\text { volume and area } \\
\text { of crow's feet } \\
\text { wrinkles. }\end{array}$ & $\begin{array}{l}\text { Neuroguard P: } \\
\text { phenoxyethanol; } \\
\text { Neuroguard G: } \\
\text { preservative-free. }\end{array}$ & $\begin{array}{l}\text { Neuroguard } \\
\text { P: } 1.5 \% \text {; } \\
\text { Neuroguard } \\
\text { G: } 3 \%\end{array}$ & $\begin{array}{c}\text { Liquid; } \\
\text { Water-soluble; } \\
\text { Processing: } \\
\text { incorporation at } \\
\text { less than } 50^{\circ} \mathrm{C} \text {. }\end{array}$ & $\begin{array}{l}\text { Protection of } \\
\text { neurons from } \\
\text { neuro-aging; } \\
\text { prevention from } \\
\text { fibro-aging; } \\
\text { decrease in } \\
\text { wrinkle depth. }\end{array}$ \\
\hline
\end{tabular}


Table 1. Cont.

\begin{tabular}{|c|c|c|c|c|c|c|c|c|c|}
\hline $\begin{array}{l}\text { Company/ } \\
\text { Supplier }\end{array}$ & Product & $\begin{array}{c}\text { Functionality } \\
\text { Category }\end{array}$ & INCI & In Vitro/Ex vivo & In Vivo & Preservatives & Use Level & $\begin{array}{l}\text { Formulation/ } \\
\text { Processing }\end{array}$ & Features \\
\hline $\begin{array}{l}\text { Codif } \\
\text { Technologie } \\
\text { Naturelle }\end{array}$ & Neurolight.61G & Skin lightening. & $\begin{array}{l}\text { Glycerin (and) water } \\
\text { (and) Pancratium } \\
\text { maritimum extract. }\end{array}$ & $\begin{array}{c}\text { Inhibition of POMC } \\
\text { expression and } \\
\text { intracellular melanin } \\
\text { synthesis (in vitro); } \\
\text { reduction of the } \\
\text { melanocyte dendricity and } \\
\text { the synthesis of receptors } \\
\text { for substance P (in vitro); } \\
\text { inhibition of the effects of } \\
\text { substance P on the export } \\
\text { of melanin (in vitro); } \\
\text { inhibition of the synthesis } \\
\text { and export of melanin } \\
\text { (in vitro). }\end{array}$ & $\begin{array}{l}\text { Reduction of the } \\
\text { surface of the } \\
\text { pigment spots; } \\
\text { clarification of the } \\
\text { pigmentation of } \\
\text { dark spots } \\
\text { without lightening } \\
\text { the pigmentation } \\
\text { of the skin. }\end{array}$ & None & $1.5 \%$ & $\begin{array}{c}\text { Liquid; } \\
\text { water-soluble. }\end{array}$ & $\begin{array}{c}\text { Neurocosmetic } \\
\text { treatment of dark } \\
\text { spots. }\end{array}$ \\
\hline $\begin{array}{c}\text { Lucas Meyer } \\
\text { Cosmetics }\end{array}$ & Progeline & Anti-aging. & $\begin{array}{l}\text { Glycerin (and) water } \\
\text { (and) dextran (and) } \\
\text { trifluoroacetyl } \\
\text { tripeptide-2. }\end{array}$ & $\begin{array}{l}\text { Reduction of progerin } \\
\text { synthesis; inhibition of } \\
\text { MMPs and elastase; } \\
\text { increase in syndecans. }\end{array}$ & $\begin{array}{c}\text { Improvement of } \\
\text { cutaneous } \\
\text { elasticity up to } \\
93 \% ; \\
\text { improvement of } \\
\text { cutaneous } \\
\text { firmness up to } \\
82 \% ; \\
\text { improvement of } \\
\text { cutaneous } \\
\text { viscoelasticity up } \\
\text { to } 42 \% \text {. }\end{array}$ & None & $0.5-2 \%$ & $\begin{array}{c}\text { Liquid; } \\
\text { Water-soluble; } \\
\text { Odorless; } \\
\text { Colorless; } \\
\text { pH usage range: } \\
4-6 ; \\
\text { Processing: } \\
\text { incorporation at } \\
\text { the end of the } \\
\text { formulation at a } \\
\text { temperature of }< \\
40^{\circ} \mathrm{C} \text {. }\end{array}$ & $\begin{array}{l}\text { Exhibition of a } \\
\text { remodeling effect } \\
\text { and reduction of } \\
\text { signs of aging: } \\
\text { sagging and } \\
\text { wrinkles; lifting } \\
\text { effect on jawlines. }\end{array}$ \\
\hline
\end{tabular}

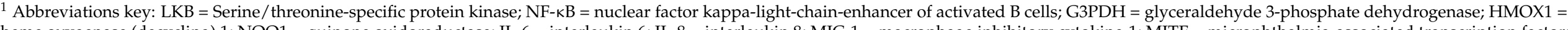

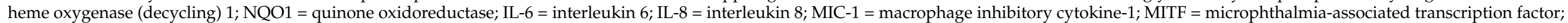

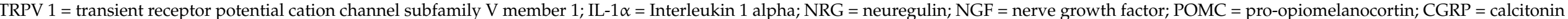

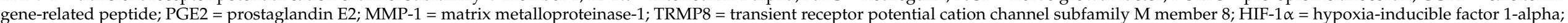
$\mathrm{FOXO}=$ forkhead box O3; MO-R1 = $\mu$-opioid receptor; $\mathrm{MC} 2 \mathrm{R}=$ melanocortin receptor 2 ; $\mathrm{sAPP} \alpha=$ soluble amyloid precursor protein-alpha 


\subsection{Neurocosmetic Ingredients for Combating Skin Stress}

The cosmetic strategies to combat skin stress are different, and neurocosmetic ingredients can be suitable for this purpose.

\subsubsection{Skin Stress and the Stress Pathway: The Role of Cortisol}

In modern life, stress is defined as the body's response to a whole range of external and psychological factors that disrupt homeostasis [71-73].

Pollution, UV radiation, blue light, insufficient sleep, social media, relationships, work-related worries, and the high number of working hours are just some of the everyday modern stressors [37].

In 1946, the endocrinologist Hans Selye proposed the term "stress" to describe a set of signals that he noticed in his patients [72]. Indeed, as reported in the literature, there are pieces of evidence that psychological stress could encourage some skin diseases-such as acne, psoriasis, dermatitis, or rosacea-or, in other cases, promote hair loss [72,74-76].

Persons' moods, emotions, and sensations occur in the brain; subsequently, the brain sends biochemical signals to the body, including the skin, producing physiological effects $[72,74,77]$.

If the exposure to stress is prolonged, skin cells do not stop the production of cortisol, also known as the stress hormone; thus, its levels remain elevated, causing a cascade of damaging consequences $[65,66,71,72]$. In this regard, the breakdown of skin homeostasis takes place, inducing inflammation and a visibly tired look [56]. Only when a feedback mechanism is established does the body return to normal physiological conditions: the stress hormones and the related consequences are eliminated, restoring homeostasis $[56,78]$. This is the field in which neurocosmetics could act.

In particular, as previously asserted, the skin and the brain are in communication for coordinating external and internal "danger" signals by cytokines, chemokines, neurotransmitters, and neurohormones.

With particular regard to cortisol, its release is mediated by the brain through the hypothalamus-pituitary-adrenal gland axis. Since the origin of the skin and the brain is the same, skin cells are also able to induce cortisol production if stimulated by external stress factors $[56,76,78,79]$.

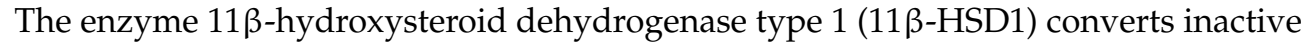
cortisone into biologically active cortisol and, as a result, under conditions of stress, the levels of cortisol in the skin increase, driving collagen to atrophy and reducing cell growth.

In aged and UV-exposed skin, cortisol production is more pronounced due to the upregulated $11 \beta$-HSD1 levels. The more stress that people feel, the more their cortisol levels increase, initiating a possible cycle in which the visible stress signs on the skin encourage a physiological stress response inside the body (Figure 2). 


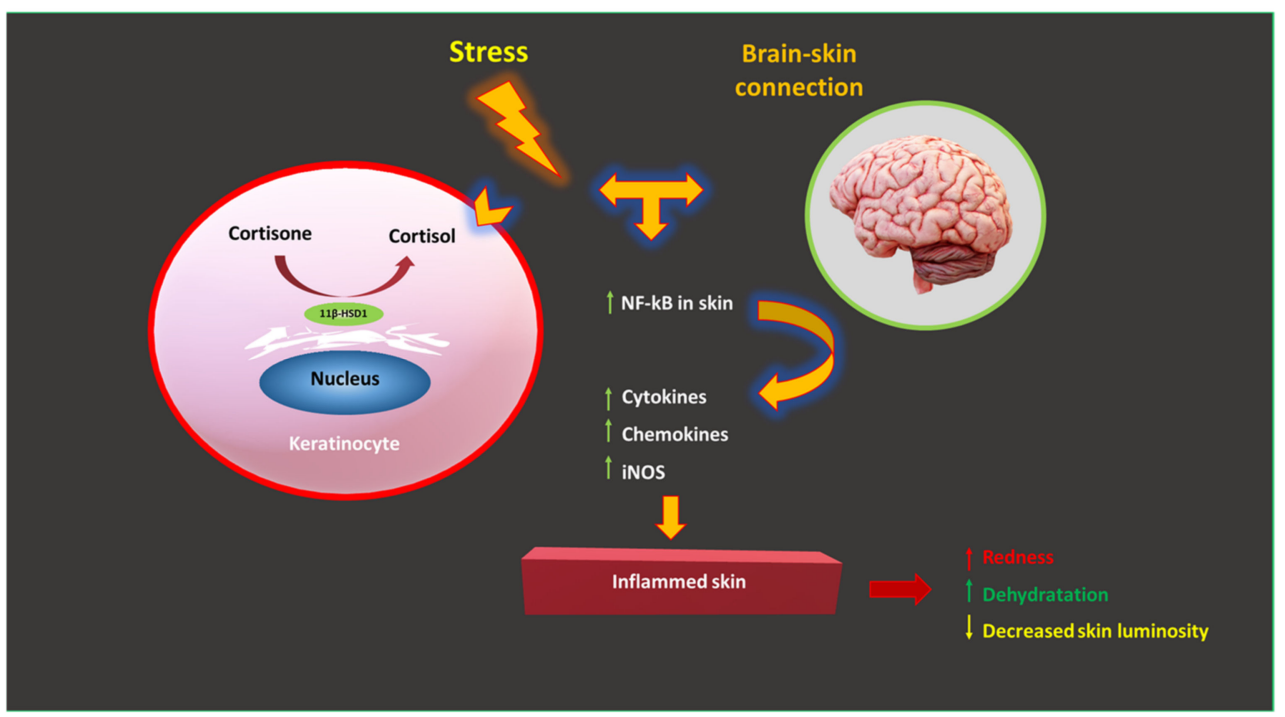

Figure 2. Diagram of the stress pathway.

More specifically, some of the negative effects of cortisol can be summarized as follows:

- Increased blood sugar levels, which promote "glycation" in the skin, damaging collagen and elastin. As a result, long-term aging and loss of the skin's ability to fully bounce back are accelerated;

- Due to the strong catabolic effect of cortisol, the degradation of dermal proteins occurs;

- Skin dryness due to the reduction in the production of hyaluronic acid-a natural moisturizer for our skin, associated with an increase in transepidermal water loss (TEWL);

- Increase in the appearance of fine lines and wrinkles, thinning skin, reduced elasticity, and lower skin barrier functionality $[72,80]$.

Some studies also reported that psychological stress induces less effective skin barrier repair $[81,82]$. Furthermore, elevated concentrations of cortisol can disrupt epidermal cohesion [82].

It was also demonstrated that the increase in cortisol levels could affect the epidermal barrier in a reconstructed human model; this was attributed to a decrease in forkhead box O3 (FOXO3) mRNA expression. FOXO3 is a gene involved in longevity and senescence [83,84]. In detail, Meyrignac et al. (2019) performed experiments using a reconstructed epidermal model with signs of senescence by knocking down FOXO3 $[85,86]$. This knockdown of FOXO3 damaged the epidermal cohesion by reducing the expression level of claudin-1 (-27.4\%) and e-cadherin $(-18.2 \%)$ - two essential proteins for the integrity of the epidermal barrier. The authors also studied the impact of the combined effects of UVB irradiation and FOXO3 knockdown [83-86].

From these considerations, some of the damages induced by stress are evident. Therefore, awareness about the impact of stress on facial skin is a topic growing in importance. In particular, young people recognize the link between the anxieties they feel and their appearance. According to an online study conducted by Lightspeed GMI/Mintel on 2000 users, $58 \%$ of people aged between 9 and 21 years agree that stress affects facial appearance.

Thus, new and inspiring stress-rebalancing skincare formulations should be considered [72].

In other words, the question is: is it possible that a cosmetic routine could help the skin to balance cortisol levels for reducing stress, with immediate and long-lasting effects? The answer is in the use of neurocosmetics for combating skin stress. 
Neurocosmetic Ingredients for Rebalancing Cortisol Levels in the Skin

For years, the company DSM studied the link between cortisol, 11 $\beta$-HSD1 enzyme activity, and skin homeostasis, contrasting one of the factors involved in visibly accelerated skin aging. The result is Bel-Even ${ }^{\circledR}$, a new DSM-patented molecule that reversibly inhibits the $11 \beta-H S D 1$ enzyme $[87,88]$. It is formulated for skincare applications to rebalance cortisol levels in the skin, improving the skin barrier, elasticity, and density. As claimed on the DSM webpage for Bel-Even ${ }^{\circledR}$, and in the corresponding brochure [87], its effectiveness was studied by using ex vivo studies on human skin cell cultures. For this purpose, the cell samples were subjected to stress, measuring the cortisol levels in both the control sample and the sample treated with Bel-Even ${ }^{\circledR}$. The first of these studies was related to the use of samples stressed via UV irradiation, and the results showed that Bel-Even ${ }^{\circledR}$, by inhibiting the $11 \beta-H S D 1$ enzyme, avoided the UV-induced type III collagen damage. The second test used cortisone as the stressor agent, revealing that, in unprotected skin, cortisone was converted to active cortisol; conversely, by adding the active ingredient Bel-Even ${ }^{\circledR}$ to cells, the transformation of cortisone to cortisol was inhibited.

However, in both stress tests, the Bel-Even ${ }^{\circledR}$ mechanism of action rebalanced cortisol levels by inhibiting the enzyme $11 \beta-\mathrm{HSD} 1$, and the results were particularly evident in keratinocytes and fibroblasts $[87,88]$. With the aim of performing in vivo tests, facial measurements of skin elasticity, density, and skin barrier strength (TEWL) were also considered. Interestingly, the facial skin elasticity appeared to be improved by $15.7 \%$ after 12 weeks of $1 \%$ Bel-Even ${ }^{\circledR}$ application when compared with the placebo. Furthermore, the active ingredient significantly increased the skin density after 4 and 12 weeks, thanks to the increased protein content in the dermis, mainly referring to collagen production $[87,88]$.

4.1.2. "Neuro-Relaxing" Anti-Aging Ingredients

The $\beta$-Endorphins: A Strategy for Skin Wellness

As previously said, if stress situations can cause imbalance in skin homeostasis, on the other hand, positive touch, such as massage or hugs, could induce the release of neurotransmitters that cause feelings of comfort and protection [89].

To better understand this condition, it should be remembered that the skin is a source of the opioid $\beta$-endorphins-neurotransmitter peptides produced at the central nervous system level that induce analgesia (absence of pain) [90,91]. In detail, by acting on the central and peripheral opioid receptors, $\beta$-endorphins inhibit the transmission signals via nervous cells from the source of the pain (nociceptor) to the spinal cord. Thus, endorphins, due to their connections with the brain's "pleasure centers", generate euphoric feelings when binding to the opiate receptors. Moreover, $\beta$-endorphins also bind their receptors to immune system cells; they seem to be involved in the fine-tuning of the immune response. $\beta$-Endorphin receptors are expressed in skin cells. In this particular case, it is demonstrated that $\beta$-endorphins can accelerate skin regeneration and wound healing. In human keratinocytes, it has been confirmed that the presence of a $\beta$-endorphin $/ \mu$-opiate receptor system is related to keratinocyte differentiation, the wound healing process, and migration [89-93].

As a result, this complex $\beta$-endorphin/ $\mu$-opiate qualitatively improves the skin's appearance [7].

Bigliardi et al. (2002) showed the involvement of the skin's $\beta$-endorphins in communication with peripheral nerve endings [94]. The authors reported that keratinocytes positive for $\beta$-endorphin staining are clustered around the terminal ends of afferent $C$-fibers, which signal the sensations of warmth, cold, or pain to the central nervous system. Moreover, the authors described the $\mu$-opiate receptor as being expressed in the dermis and epidermis nerve fibers. It has been supposed that keratinocytes can communicate directly with the nervous system due to the opiate receptor system; hence, this should open potential therapies for skin diseases-for example, atopic dermatitis and psoriasis [94].

Another interesting aspect regarding $\beta$-endorphin synthesis is POMC processing. As discussed before, endogenous opioids-a group of peptide hormones that include 
$\beta$-endorphins, enkephalins, and dynorphins-are produced by our body. They share the N-terminal amino acid sequence Tyr-Gly-Gly-Phe-X (X = Met or Leu), necessary to bind to the opioid receptor [95]. The proopiomelanocortin (POMC) - a protein that contains 267 amino acid residues - is a precursor of these peptide hormones, and $\beta$-endorphin is one of them, originating from its cleavage [95-98]. Among other peptide hormones derived from POMC, it is worth mentioning the adrenocorticotropic hormone (ACTH)—also known as corticotropin, which stimulates the adrenal cortex to secrete the anti-inflammatory and anti-allergic hormone cortisol — and the melanocyte-stimulating hormone (MSH), which is involved in skin pigmentation $[99,100]$. Generally, the POMC and the related cleavage products are produced mainly in the hypothalamus and the pituitary gland's anterior lobe, but the in situ production of POMC and its products (ACTH, MSH, $\beta$-endorphins, and their corresponding receptors) has also been revealed in skin cells $[97,99,101]$. Indeed, it has been proposed that the cutaneous POMC system acts in an autocrine manner in response to external or internal stresses, evidencing the effect of opioids on skincare and presenting the necessity of "neuro-relaxing" cosmetic ingredients derived from plant extracts, suitable for the formulation of anti-aging products [102-106].

\section{Discovering Neurocosmetic Ingredients from Plant Extracts}

To ensure skin regeneration and vitality, MIBELLE BIOCHEMISTRY developed Happybelle-PE, a Vitex agnus-castus extract encapsulated in a double delivery system designed to control the release of phyto-endorphins along with their bioavailability in order to obtain anti-aging benefits and radiant skin [107-110].

The chaste tree (Vitex agnus-castus), also known as monk's pepper, is a medicinal plant from the Mediterranean area and Asia that produces aromatic berries rich in phytoendorphins. These compounds bind to the $\mu$-opiate receptor, stimulating the in vivo production of $\beta$-endorphins, thus offering benefits for skincare [111-115].

These dried monk's pepper berries are treated in ethanol, glycerin, and $\beta$-cyclodextrin. The final ingredients consist of monk's pepper berry extract, lecithin, tocopherol (vitamin E), ascorbyl tetraisopalmitate (vitamin C-ester), and $\beta$-cyclodextrin. The combined use of $\beta$ cyclodextrin and lecithin leads to a double vector system: the hydrophobic monk's pepper berries are hosted in the $\beta$-cyclodextrin cavity, and these complexes are enclosed in the lecithin liposomes; the lipophilic vitamins are encapsulated in a nanoemulsion, stabilized with lecithin $[107,109,112,116]$. The in vitro studies showed that the complex stimulated the cell activity and increased the production of type I and III collagens [109]. Another in vitro study performed on human keratinocyte cells has shown that Happybelle-PE favors cell proliferation [109], while, in vivo tests demonstrated the increase in skin hydration (up to $28 \%$ within 28 days), skin firmness (up to $20 \%$ ), and the decrease in the wrinkle depth of crow's feet (by more than 20\%) [89,107,109-111].

The phyto-endorphin complex extracted from the berries of the Vitex agnus-castus shrub also characterizes the JOYDERM cosmetic line. In this case, the phyto-endorphin complex acts topically to improve skin hydration, cell vitality, skin regeneration, and melanogenesis regulation - essential for skin wellbeing and preventing skin aging $[114,117,118]$.

With Happy Skin, PROVITAL discovers Rhodiola rosea root extract's benefits to stimulate the production of $\beta$-endorphins in the skin, granting it a more glowing appearance [119-121].

NUXE cosmetic company dedicated part of its studies to the formulation of the cosmetic line Nirvanesque, which shows the "neuro-relaxing" properties of Paeonia suffruticosa extract. Interestingly, NUXE performed its researches by adopting a "reverse pharmacognosy" approach. By considering that the skin releases enkephalins through nerve fibers, NUXE Laboratories established that enkephalins are the molecules of skin relaxation [5], being able to reduce stress messages. Starting from these considerations, the aim was to fight the appearance of the "stress"-related expression of microcontractions and wrinkles. Unfortunately, enkephalins exhibit a very short lifetime (about 20 seconds), because the enkephalinase enzymes rapidly destroy them [122]. Thus, intending to extend the lifetime 
of enkephalins, NUXE performed a screening of 165,000 plants, identifying those containing a sufficient amount of pentagalloyl glucose (PGG) - the molecule able to inhibit the activity of enkephalinases [123-125]. This approach allowed them to find Paeonia suffruticosa (tree peony), a perennial plant with large blooming flowers that originally comes from Tibet, but it is also found in Europe, and has been used in traditional Chinese pharmacopeia for more than a millennium. Its root is collected in the fall, dried under the sun, and used raw or roasted $[123,126,127]$. Thus, NUXE began to produce the tree peony root concentrated extract (with patent pending), in blend with blue lotus seed, poppy seed, and althea root, resulting in Nirvanesque, which exhibited a double neurocosmetic action: a "Botox-like" booster for reducing skin's micro-tensions (wrinkles), and an enkephalinase inhibitor [128].

LANCÔME has created the exclusive NeuroCalm ${ }^{\mathrm{TM}}$, a complex rich in Peonia suffruticosa (Paeonia Suffruticosa extract/Paeonia Suffruticosa root extract), French rose (Rosa gallica extract/Rosa gallica flower extract), Crithmum maritimum extract, and Moringa (Moringa pterygosperma seed extract) extract introduced in the Hydra Zen cream, formulated to neutralize the effects of environmental stress on the skin. The Hydra Zen "Antistress" soothing day cream moisturizes, nourishes, and protects facial skin from external aggressions such as wind and air conditioning, which can promote its dehydration. Thanks to its soft texture, suitable for all skin types (very dry, dry, normal, mixed, oily, impure, mature, or sensitive), the cream is rapidly absorbed, leaving a soft, smooth, and radiant skin face [129]. GIVAUDAN performed a specific extraction process for obtaining a concentrated extract enriched in specific sugars, including stachyose and ciceritol, from the seeds of Tephrosia purpurea $[89,130,131]$, creating Neurophroline ${ }^{\mathrm{TM}}$ [78]; it is designed to combat the multiple stress source effects present daily $[56,130,132]$. In detail, Neurophroline ${ }^{\mathrm{TM}}$ works to reduce the production of cortisol by skin cells $(-70 \%$ within $2 \mathrm{~h}$, in vitro) and to stimulate the release of $\beta$-endorphins ( $+163 \%$ within $24 \mathrm{~h}$, in vitro). Moreover, when human keratinocytes and fibroblasts were incubated with Neurophroline ${ }^{\mathrm{TM}}$ at $1 \%$, a significant stimulation in the gene expression involved in the skin cells' homeostasis was observed. Specifically, Neurophroline $^{\mathrm{TM}}(1 \%)$, in both keratinocytes and fibroblasts cells, if incubated for 24 or $48 \mathrm{~h}$ (in vitro), promoted the expression of the major marker proteins involved in cellular stress response and oxidative stress, i.e., the heme oxygenase 1 (HMOX1) (up to 3000\%), and the NADPH quinone dehydrogenase (NQO1) (200\%). In ex vivo tests, the action of Neurophroline ${ }^{\mathrm{TM}}$ on the production of the HMOX1 and NQO1 proteins was studied using reconstructed human epidermis (RHE). RHE was topically treated for 2 days with Neurophroline ${ }^{\mathrm{TM}}$ at $1 \%$ in a placebo formula, or with positive controls. To quantify the expressed amounts of HMOX1 and NQO1, the RHE was then analyzed by immunofluorescence assay [78]. As a result, an improvement of the epidermal matrix, the reduction of inflammation and redness (by boosting HMOX1 up to $888 \%$ ), and the stimulation of natural superoxide scavenger activity for advanced antioxidant and pollution protection (increases NQO1 up to 528\% within 2 days) were observed [89].

Neuphroline's in vivo efficacy was also demonstrated: within 2 weeks, Neurophroline $^{\mathrm{TM}}$ significantly recovered volunteers' skin color and luminosity, even when tested in polluted environments, and visibly reduced the signs of stress after one month of use. In particular, dark circles, eye bags, and the appearance of redness were reduced, confirming its fast action on stress relief $[78,89]$. Due to these properties, Neurophroline ${ }^{\mathrm{TM}}$ can be used to formulate anti-aging night and day creams, antistress/fatigue serums, and eye care products [78].

GIVAUDAN proposed the same Tephrosia Purpurea seed extract to formulate body sculpting products—such as Betaphroline, which stimulates the release of $\beta$-endorphins $[56,133]$.

\subsubsection{Neurocosmetics as a Strategy to Combat Inflammatory Responses Related to Skin Stress}

It has been reported that the constant exposure to stress affects NF- $\mathrm{KB}$ (nuclear factor kappa-light-chain-enhancer of activated B cells) transcription factor in skin keratinocytes, increases cytokines, chemokines, and inducible nitric oxide synthases (iNOS), promotes cell inflammation, redness, dehydration, and dull skin tone, and worsens rosacea-prone 
skin $[89,134-137]$. To reduce (up to $10 \%$ in vivo) the skin inflammation and redness induced by stress, PROVITAL launched Agascalm, a flower/leaf/stem extract derived from Agastache mexicana, to provide a solution for inhibiting the release of cytokines (up to $104 \%$ in vitro) and the movement of NF- $\mathrm{kB}$ transcription factor to the nucleus (up to $70 \%$ in vitro) [138-140]. Additionally, the improvement of vascular tonicity and the restoration of the skin's moisture barrier (reducing water loss up to 13\% in vivo) are other benefits. More youthful skin radiance and skin tone for a more uniform complexion are further effects [89].

To boost skin comfort by reducing inflammation, Sepicalm S WP and Sepicalm VG WP (both Seppic) - derived from Nymphaea alba flower extract, combined with amino acids and minerals-are presented to soothe irritation, calm redness, and relieve any stinging sensation $[141,142]$. These ingredients work by limiting the transcription factors necessary for the expression of inflammatory genes, reducing inflammation on both the dermal and epidermal skin layers by reducing IL-6 and IL-8 (key inflammatory mediators) and their expression, and by favoring the skin's production of $\beta$-endorphins. The in vivo test results showed an overall soothing effect and an improvement in skin radiance $[89,143]$.

\subsubsection{Intriguing Hints about Sleep-Related Beauty: The Melatonin Receptor MT1}

It was reported that the melatonin receptor, MT1, is related to sleep and beauty. In this regard, for example, the relationship between atopic dermatitis and sleep disorders is well documented $[144,145]$. Disorders of the circadian rhythms can locally affect melatonin synthesis in the skin. Indeed, poor sleep efficiency is associated with increased cortisol-induced stress reactivity. Consequently, skin inflammation is caused by destroying the collagen content and reducing the skin's blood flow efficiency, producing a subsequent decrement of oxygen and amounts of nutrients. The eyes are particularly affected, manifesting dullness and dark circles, making the skin look older [146-149].

Several articles reported the connection between beauty sleep-understood as an alternative to the alteration of circadian rhythms-and skincare ingredients via the skinbrain connection, based on their studies on the activity of melatonin and its receptor MT1 in skin cells [150-152].

In particular, a study presented at the 25th IFSCC conference on "CosmEthic Science and Conscience", (Milan, 30 September-2 October, 2019) tested the efficacy of a topical formulation with sunflower stem cell extract (Helianthus annuus cell culture extract, HACCE; rich in flavonoids, polyphenols, and "phyto-melatonin") as an alternative to melatonin, by monitoring notable in vitro parameters in stressed and unstressed cells (such as melatonin MT1 receptor gene expression, antioxidant activity, mitochondrial cell membranes, and so on), observing many clinical benefits related to the skin-brain connection, stress reduction, and improved skin quality. Overall, HACCE extract exhibited very promising results: in vitro studies using HACCE at $0.002 \%$ as an optimal concentration were performed in order to evaluate melatonin MT1 receptor gene expression in cells in the absence of stress (estimated about $+130 \%$ ), and in the presence of UV radiation (estimated about $+117 \%$ ) as a stressor. The means of MT1 signaling was studied, observing a reduction $(-99 \%)$ in cyclic adenosine monophosphate (cAMP) in forskolin-stimulated cells and a consequent decrease in adenylyl cyclase activity. Furthermore, in vitro antioxidant activity tests were also performed: SOD and catalase gene expression in fibroblasts were quantified by ELISA in the absence of stress and under UV irradiation, observing similar activities in all different antioxidative enzymes (SOD 1, 2, and catalase).

In vitro experiments on mitochondrial cell membranes and mitochondrial cells stressed by $\mathrm{H}_{2} \mathrm{O}_{2}$ were also objects of the study. In particular, by using HACCE at $0.002 \%$, an ROS (reactive oxygen species) reduction in stressed cells of about $-18 \%$ and $-26 \%$, respectively, was observed.

Finally, in the in vitro experiments on the extracellular matrix, an increase in the type I and III collagen gene expression $(+42 \%$ and $+31 \%$, respectively, by ELISA quantification), 
and a matrix metalloproteinase-1 (MMP1) gene expression decrease $(-17 \%)$, were also observed when applying a HACCE concentration fixed at $0.002 \%$.

The HACCE "antistress" melatonin-like activity was also demonstrated by performing in vivo experiments. Female volunteers of self-described stressed conditions applied a product formulated with HACCE 2 times daily. Their stress levels were recorded by a stressometer and measured by an endpoint datum, which showed a significant decrease in stress index after using a 1\% HACCE complex for 1 month. Thus, the activation of the MT1 receptor in the skin could safely reinforce its natural defense responses by attenuating the aging-associated stress signs; this promotes skin repair and beauty, demonstrating the skin-brain connection [153].

\subsection{Neurocosmetic Ingredients for Sensitive Skin}

\subsubsection{Neuro-Sensitization of the Skin}

The concept of "sensitive skin" is a complex dermatological condition defined by abnormal sensory symptoms. According the International Forum for the Study of Itch (IFSI), sensitive skin is definable as follows: "a syndrome defined by the occurrence of unpleasant sensations (stinging, burning, pain, pruritus, and tingling sensations) in response to stimuli that normally should not provoke such sensations. These unpleasant sensations cannot be explained by lesions attributable to any skin disease. The skin can appear normal or be accompanied by erythema. Sensitive skin can affect all body locations, especially the face" [154]. Approximately half of the population considers their skin to be sensitive, mainly women [155-157]. Three main types of sensitive skin can be considered, and as a whole, their manifestations could be ascribed to reduced barrier functions, inflammation with an intact barrier function or, commonly, to healthy individuals having skin that overreacts to environmental factors (wind, pollution, UV, temperature changes, and so on), detergents, cosmetics, or clothes [155].

These reactions can range from slight discomfort to frequent visible skin irritation signs, such as redness. In detail, the adverse reactions refer to objective/visible and subjective/sensory symptoms - for example, tightness, stinging, burning, and tingling, or sometimes pain, itching, and discomfort [155,158-161].

Thus, it appears that these manifestations involve cutaneous nerve fibers [162-164] due to the overactivation of transient receptor potential (TRP)-type receptors in the skin, which leads to constant inflammation and local redness. In detail, with regard to TRP receptors, the attention should be focused on the transient receptor potential ion channels subfamily V member 1 (TRPV1) involved in neuroinflammation. [165-169].

\section{The Molecular Basis of Sensitive Skin: TRPV-1-Mediated Neuroinflammation}

It is known that an important role in the transduction of pain from a variety of environmental stimuli is played by TRP channels - in particular, the TRPV1 vanilloid receptor. This receptor responds to different irritant stimuli-such as temperature (heat), pH (acids), and some chemical compounds (for example capsaicin)-by opening the transmembrane channel, allowing the influx of $\mathrm{Ca}^{2+}$ ions inside the cell $[155,163,170,171]$. The result is the activation of the signaling pathway, which promotes the release of neuromediators able to induce inflammation, pain, and itching sensations [155,166,171].

In general, TRPV1 receptors are largely present in sensory nerve cells, but it is worth remembering that they are also expressed in keratinocytes and fibroblasts [155,166,172,173].

Since the keratinocytes are the first cell types exposed to external stimuli, they can quickly induce the pain signal to the underlying nerve cells. In sensitive skin, an increase in the nervous response to harmless environmental influences is often due to an overreaction of the TRPV1 receptor, attributable to the lower activation threshold and higher expression levels of TRPV1 [163,167,174].

Interestingly, TRPV1 also plays a role in skin aging. Indeed, it was shown that in photo-aged human skin, TRPV1 is usually overexpressed $[170,175,176]$. Furthermore, the constant activation of TRPV1 caused, for example, by heat and/or infrared radiation, leads 
not only to inflammation, but also to the upregulation of enzymes that destroy collagen in the skin, inducing premature skin aging [155,175,177-179].

The inflammation process develops through the classical pathway that involves the release of cytokines (interleukins), with visible effects, and neuroinflammation perceived differently by each subject. When external factors interact with the skin, as the first step, the keratinocytes release interleukin- $1 \alpha(\mathrm{IL}-1 \alpha)$, provoking an immediate inflammatory response $[89,180,181]$. As the second step, the keratinocytes communicate with neuron fibers through the nerve growth factor (NGF) (overexpressed during inflammation processes, [27]), which activates a specific receptor-the tropomyosin receptor kinase A (trkA) - which, in turn, interacts with the TRPV1 receptor, enhancing its expression levels at the surface of the nerve fibers [182-185].

Since TRPV1 controls the release of neuropeptides and delays the recovery of the skin barrier function, the diffusion of many inflammatory mediators occurs. Thus, increased sensitivity of nociceptors to noxious stimuli manifests, leading to long-term skin sensitivity $[167,186]$.

Moreover, all of the stress effects discussed so far are worsened by aging and lack of sleep [166].

TRPV1 receptor activation is also involved in atopic skin (atopic dermatitis) - a chronic inflammatory disease with a prevalence of $25 \%$ during childhood and $7-10 \%$ in adults [186-188]. Atopic dermatitis is a skin physiopathology caused by to impaired skin barrier function and neurogenic inflammation, which manifests as significant skin dryness and red spots frequently covered by small vesicles (small "bubbles") that cause a strong itching (85\% of subjects) [189]. It is really the activation of TRPV1 that increases oxidative stress and causes itching and burning sensations. Indeed, by blocking TRPV1, the skin barrier function improves $[188,190,191]$. Thus, a possible solution for sensitive skin is to strengthen the tolerance level by reducing the reactivity of TRPV1 $[155,186,190]$.

\subsubsection{Providing Solutions for Sensitive Skin: Neurocosmetic Ingredients}

Perfect skin is a common consumer desire. However, this goal is not easily achievable, because several "stressors" exist that render the skin tone irregular. For these reasons, there is a strong need for functional cosmetic ingredients that protect the skin. As an example, Mariliance ${ }^{\mathrm{TM}}$ by GIVAUDAN is claimed to be a "neuro-soothing" extract derived from Rhodosorus marinus, a red microalga [89,158,162,185,192,193]. In order to assess the sensitivity of skin towards external stimuli, in vitro tests using Mariliance ${ }^{\mathrm{TM}}$ demonstrated that it downregulates TRPV1 expression in astrocytes and inhibits the release of neuroinflammatory mediators, with particular reference to IL-1 $\alpha$ and NGF $[162,166]$.

This product's efficacy through the skin layers was further evaluated by performing ex vivo and in vitro penetration tests. In particular, its capacity for reducing skin sensitivity was demonstrated by using the clinical evaluation of capsaicin. Mariliance ${ }^{\mathrm{TM}}$ significantly decreased the pain sensation, and $100 \%$ of panelists confirmed that a cream containing this ingredient at $3 \%$, soothes and softens the skin by inducing a general feeling of comfort. Thus, thanks to these properties, Mariliance ${ }^{\mathrm{TM}}$ can be used to formulate day creams, cold creams, after-sun products, and shampoos for sensitive skin, and is also suitable for formulating post-depilatory, post-peeling, and after-shaving cosmetic products [162,192].

MIBELLE BIOCHEMISTRY proposes Pinolumin, an extract from Swiss stone pine wood that contains high amounts of pinosylvin, a stilbenoid resveratrol-like molecule [194]. The idea of its use as a "neuro-relaxing" ingredient in cosmetic products derived from interesting research demonstrating that, when sleeping in a Swiss stone pine bed, the pine wood stimulates relaxation during deep sleep phases and reduces the heart rate [195-197].

More detailed studies about its action mechanism showed that the Swiss stone pine extract inhibits the TRPV1 receptor, protects skin collagen by preventing the UVA-induced production of MMP-1 (matrix metalloproteinase-1, a collagen-degrading enzyme), and reduces the production of inflammatory markers during oxidative stress, as well as local redness and age spots [198,199]. 
Oxidative stress induced by ROS—-generally caused by pollution, UV light, or aging processes-leads to inflammation and, consequently, skin redness. The exposure to UV light upregulates MMP-1 and stimulates melanin overproduction, resulting in the formation of age spots [200,201]. Pinosylvin not only neutralizes free radicals by upregulating heme oxygenase-1, but also reduces the amounts of intra- and extracellular ROS. Furthermore, by inhibiting inflammatory gene expression, pinosylvin reduces skin inflammatory responses and neuroinflammation $[199,202]$.

Swiss stone pine extract's ability to modulate sensory neuron activation was evaluated in a cell culture model simulating the irritation of nerve endings due to TRPV1 receptor activation. In particular, sensory neurons were irritated using capsaicin-a TRPV1 receptor agonist-both in the presence and absence (control) of Swiss stone pine extract. In the case of irritated neurons, they reacted by releasing the calcitonin gene-related peptide (CGRP), provoking vasodilation and histamine release, along with activating inflammatory pathways. Meanwhile, in the presence of the Swiss stone pine extract, the dose-dependent CGRP release induced by capsaicin was reduced, suggesting a soothing effect. Indeed, in vivo studies demonstrated that Pinolumin, when present at $2 \%$, improved skin tone homogeneity, with a visibly radiant skin appearance [166,203].

Skinasensyl ${ }^{\circledR}$ LS 9749 (liquid synthetic tetrapeptide) and Skinasensyl ${ }^{\circledR}$ LS 9852 (powdered synthetic tetrapeptide) from BASF are other two functional ingredients designed to soothe sensitive skin [204-206]. These ingredients improve skin comfort by reducing overreactions that lead to burning and stinging [207]. Furthermore, both Skinasensyl ${ }^{\circledR}$ LS 9749 and Skinasensyl ${ }^{\circledR}$ LS 9852 inhibit the release of the neuromediator CGRP from sensory neurons, and increase the skin's tolerance threshold [207-209].

With the aim of relieving sensitive skin, Wandrey et al. (2017) studied a bioinspired peptide from the analgesic component of sea anemone (Heteractis crispa) venom protein, proposing it as a novel neurocosmetic soothing ingredient, with interesting effects soon after the first application [210]. Interestingly, in the venom of the leathery sea anemone, scientists have discovered a small protein called analgesic polypeptide HC1 (APHC1), which was the first polypeptide inhibitor of the TRPV1 receptor [211-213]. It was also shown that treatment with APHC1 improved the effects on the pain response in both acute and chronic pain models [214]. Therefore, this protein is a very interesting molecule for targeting TRPV1 to reduce irritation in sensitive skin [215].

A supramolecular assembly made of a shea-butter-based soft sphere carrier system incorporating the peptide was proposed for improving the skin's peptide uptake and protecting it from degradation. An in vitro assay showed that this peptide reduced the activation of the TRPV1 pain receptor. During clinical studies, the increase in the skin's electrical current perception threshold (CPT) - measured using a Neurometer-also demonstrated its ability to decrease the skin's reactivity and sensitivity towards an irritant stimulus; thus, the skin appears more resistant to environmental stresses $[210,216]$.

Thanks to the studies on the sea anemone protein, a pentapeptide (RRRFV) was designed to mimic the TRPV1 binding sequence for formulating soothing cosmetic products. The peptide was synthetically produced in order to respect sustainability and purity requests, and the resulting soothing active ingredient SensAmone P5 by MIBELLE BIOCHEMISTRY was obtained [217]. A placebo-controlled double-blind clinical study was performed on volunteers with sensitive skin in order to assess the related skin-comforting properties via in vivo tests. In detail, a cream containing $2 \%$ SensAmone P5 was applied on one half of the subjects' faces, while the corresponding placebo cream was applied on the other half. The obtained results revealed that the single application of the $2 \%$ soothing active ingredient increased the $\mathrm{CPT}$, suggesting a reduced reactivity of the skin towards external stimuli $[210,218]$.

Interestingly, Fatemi et al. (2016) identified the inhibitory effect of bPOMC - an innovative POMC-derived biomimetic tripeptide present in Neutrazen ${ }^{\mathrm{TM}}{ }^{\text {, by LUCAS MEYER }}$ COSMETICS - on humans' sensory irritation induced by capsaicin. To improve its penetration and efficacy, bPOMC was linked to a lipid [27]. The authors reported that bPOMC 
soothed irritated skin, and maintained and restored the sensitivity threshold of normal skin without affecting melanogenesis. It was concluded that the bPOMC reduced the capsaicin-induced inflammation by limiting the release of substance $\mathrm{P}$ and preventing the release of IL-1-induced IL-8 [27].

These considerations can be better understood by considering that the skin is also a target organ for POMC peptides, whose activities determine antagonism and downregulation of adhesion molecules and reduce inflammation by modulation of IL-10 production [121]. POMC peptides are expressed by melanocytes, keratinocytes, fibroblasts, microvascular endothelial, mast, Langerhans, and immune cells (monocytes and macrophages) [100]. Thus, to organize the skin's stress response system against local stress, the skin's neuroendocrine system - regulated by POMC peptides - should interact with the skin's immune system $[103,180]$.

In detail, the POMC peptides exert their effects through five subtypes of heterodimeric G-protein-coupled receptors with seven transmembrane domains indicated as melanocortin receptors (MC-1R through MC-5R) [96,100,110].

During in vitro experiments, it has been observed that POMC binds to melanocortin-1 receptor (MC1-R), reducing the production of interleukin 8 (IL-8)-a proinflammatory chemokine that is involved in the pathogenesis of some inflammatory skin diseaseswithout affecting melanogenesis $[100,219,220]$.

Experimental evidence revealed that both neuropeptides and neurohormones exert an important immunoregulatory role, and that the articulated cascade of mediators that interact with one another is involved in the physiopathology of sensitive skin. In particular, the latter refers to a nonspecific reaction that involves cutaneous sensory innervation through unmyelinated $(\mathrm{C})$ or myelinated $(\mathrm{A} \delta)$ fibers that respond to a wide range of chemical and physiological stimuli $[27,176,221]$.

For example, sensitivity to capsaicin is mediated by non-mechanosensory $C$ fibers, while during heat perception, mostly mechanosensory $C$ fibers and BC fibers are involved [29,222].

The application of capsaicin to the skin boosted the noxious stimuli: it binds to the TRPV1 receptor and activates the $C$ nerve fibers, resulting in the appearance of redness and local inflammation-a process called "neurogenic inflammation" [174]. Thus, starting from these considerations, this biomimetic peptide bPOMC should represent another strategy to inhibit sensory irritation [27]. For example, when used for formulating skincare products, bPOMC reduces the symptoms of contact dermatitis [110].

It should be remembered that the POMC peptide chain, synthesized and released by keratinocytes, contains the $\beta$-endorphin sequence which, in turn, contains enkephalin-a pentapeptide composed of Tyr-Gly-Gly-Phe-Met/Leu, found near epidermal nerve endings (Merkel cells) [100,223]. It has also been supposed that the anti-pruritic effectiveness of opioids is due to their action on these nerve fibers. Furthermore, cooperation between the calcitonin gene-related peptide (CGRP) and opioids in the suppression of the pain process can also be considered: the main effect is centered on met-enkephalinergic neurons, which release their opioids under the stimulation of CGRP. Some opioid peptides, synthesized by epidermal and nervous cells, can act at the CGRP-releasing sensory nerve level to soothe skin [29].

Other interesting experimental studies reported that the endogenous dipeptide TyrArg named kyotorphin, discovered in 1979, has receptors that activate calcium influx (IP3 gate) by releasing met-enkephalin, inducing analgesia [209,224,225]. However, kyotorphin is not suitable for cosmetic applications due to its hydrophilicity, which prevents it from reaching the epidermis. Lintner et al. (2009) derivatized the peptide to improve its bioavailability by synthesizing N-Acetyl-Tyr-Arg-Hexadecyl ester (NATAH) [29]. This lipopeptide is commercially available from SEDERMA under the name Calmosensine [226].

As a first step of the study, human keratinocytes were incubated with different concentrations of the NATAH peptide for $24 \mathrm{~h}$, with the aim of investigating its pseudo-opioid ability for upregulating the gene responsible for POMC synthesis. Indeed, the POMC 
increase, observed in the presence of the NATAH peptide, indicates an improved secretion of opioid derivatives such as the keratinocyte met-enkephalin. In a second step, the NATAH-mediated CGRP modulation was studied. During in vitro experiments, sensory neurons spontaneously released CGRP into the culture medium. This phenomenon was also observed after stimulation with different stressors (capsaicin, for example), indicating the neuronal activation and the existence of action potential. With the NATAH peptide, marked desensitization was noted at a concentration of $5 \mathrm{ppm}$, reducing CGRP secretion to half its baseline value. As a result, it appears that NATAH has the profile of a potential soothing and "relaxing" neurocosmetic ingredient [29].

DEFENSIL ${ }^{\circledR}$-SOFT by RAHN AG is a neuro-soother formulation based on the extract of an edible mushroom Albatrellus ovinus, and proposed as a functional ingredient [227]. Due to the presence of the bioactive phenolic compounds grifolin, neogrifolin, and scutigeral in this extract, the effective inhibition of the TRPV1 receptor was observed during in vitro studies $[203,228,229]$. Furthermore, when applied to the skin, DEFENSIL ${ }^{\circledR}$-SOFT provides soothing (in vivo study) and anti-aging effects [230]. In detail, from in vivo and in vitro studies, it has been reported that DEFENSIL ${ }^{\circledR}$-SOFT counteracts neuroinflammation, reduces skin irritation, and soothes hyperalgesic skin, as well as preventing IR aging by protecting skin from IR-induced heat stress [227].

On the whole, DEFENSIL ${ }^{\circledR}$-SOFT delays intrinsic and extrinsic skin aging, as well as thermal aging, and resets the skin's pain threshold.

Based on the relatively recent scientific evidence that POMC-derived neuropeptides exert anti-inflammatory activity in the skin through the binding to-and subsequent activation of-MC1-R, LUCAS MEYER COSMETICS developed Neutrazen ${ }^{\mathrm{TM}}$, a soothing lipopeptide derived from the $\alpha$-MSH sequence, particularly suitable for sensitive skin $[231,232]$; it is composed of three amino acids coupled with palmitic acid to help its absorption through the skin. Among the other biomimetic peptides tested in in vitro experiments, Neutrazen ${ }^{\mathrm{TM}}$ demonstrated a high binding affinity for MC1-R (comparable to that of $\alpha-\mathrm{MSH}$ ), a weak melanogenic activity, and the ability to counteract the skin's inflammatory processes [27].

Generally, the in vitro experiments showed that $\alpha$-MSH downregulates the production of proinflammatory cytokines such as IL-1, IL-6, IL-8, and TNF- $\alpha$ and, conversely, upregulates the production of the cytokine synthesis inhibitor IL-10 [233-235]. Part of the anti-inflammatory effect seems to be mediated by the inhibition of nuclear factor kappa $\mathrm{B}(\mathrm{NF}-\mathrm{kB})$ at a molecular level. $\alpha$-MSH binds MC1-R with a high affinity, exerting antiinflammatory activity, as confirmed by experiments carried out using MC1-R-selective synthetic agonists [236,237]. Many skin cells are targets for the anti-inflammatory effects of $\alpha-\mathrm{MSH}$, including monocytes, macrophages, dendritic cells, keratinocytes, melanocytes, fibroblasts, and endothelial cells [238]. Keratinocytes respond to external stimuli such as UV radiation by producing interleukins, which act as messengers mobilizing inflammatory cells. The first cytokines to be released are IL- 1 and TNF- $\alpha[103,239]$. In the skin, interleukin-driven inflammatory reactions are a major cause of erythema (redness) and edema (swelling) [240,241]. In this regard, for example, Neutrazen ${ }^{\mathrm{TM}}$ reduces UVB-induced inflammatory response, and consequently protects from the harmful effects of sun exposure. In vitro tests showed that in keratinocytes, it downregulates the production of UVB-induced inflammatory cytokines such as interleukin 8 (IL-8), and in fibroblasts inhibits the release of IL-1-induced IL-8, reinforcing its anti-inflammatory potential. When tested ex vivo, Neutrazen ${ }^{\mathrm{TM}}$ inhibited neurogenic inflammation by reducing the effects of substance P on skin explants. More specifically, the addition of Neutrazen ${ }^{\mathrm{TM}}$ to skin explants reduces edema formation (by $60 \%$ ), inhibits blood vessel dilation in the presence of substance $\mathrm{P}$, and prevents the release of TNF- $\alpha$ produced during substance-P-induced neurogenic inflammation. Knowing that neurogenic inflammation is linked to photo-aging, Neutrazen ${ }^{\mathrm{TM}}$ potentially also prevents the signs of premature aging of/on the skin. Clinical studies were performed to evaluate and compare the anti-inflammatory and anti-irritant efficacy of a Neutrazen ${ }^{\mathrm{TM}}$ formulation when applied as preventive care or soothing care on chemically challenged skins. The chemical agent used for these tests was sodium dode- 
cyl sulfate (SDS) — an anionic surfactant-at a concentration of $0.5 \%$. The results proved that Neutrazen ${ }^{\mathrm{TM}}$ effectively reduces redness in SDS-challenged skin, and successfully alleviated the signs of inflammation. Thus, it can be recommended for soothing care to maintain a normal skin sensitivity threshold. Additionally, after performing consumer tests, it appeared that Neutrazen ${ }^{\mathrm{TM}}$ quickly reduces sensations of burning, tingling, and irritated skin, soothes itching, and provides protection and skin comfort. Overall, visibly smoother skin, reduced wrinkles, healthier and more radiant complexion, and an increased inflammatory resistance were observed [242].

4.2.3. Providing Solutions for Sensitive Skin: "Coolant" Neurocosmetic Ingredients An Insight about the Skin Sensation: Warm and Cold Receptors

Cutaneous skin sensitivity refers to sensory inputs from the skin surface, and describes the neurobiological processes that confer to the skin the ability to "sense." When cosmetic products are applied onto the skin's surface, the skin's sensory neural architecture is highly receptive to different physicochemical forms of stimulation: the skin's sensations can be described by referring to touch, temperature, itch, and pain, which are related to different receptors [4]. In particular, these sensations, by traveling along different pathways, reach different targets in the brainstem. The sensory information is thus represented in the brain in the primary and secondary somatosensory cortex, where the contralateral body surfaces are mapped in each hemisphere.

Focusing the attention on the effect that temperature could have on the skin, it is worth mentioning that the cutaneous somatosensory system can detect an impressive range of temperature changes.

The free nerve endings for cold- or warm-sensitive nervous fibers are located beneath the surface of the skin, and can sense temperature changes, not absolute temperature. Particularly, non-glabrous skin contains a system of nerves that specifically code for the pleasant properties of touch [4].

The thermal stimuli that differ from the homeostatic condition excite specific temperaturesensory nerves in the skin, and transmit this change to the spinal cord and brain. There are two kinds of thermosensory fibers: warm and cold receptors, which respond to warmth and cold, respectively. These receptors can be distinguished from nociceptors that respond to noxious low and high temperatures $\left(<20^{\circ} \mathrm{C}\right.$ and $\left.>45^{\circ} \mathrm{C}\right)$, and also from thermosensitive mechanoreceptors [4].

In this ambit, the cooling ingredients-intended to work on a neurological level by eliciting a feeling of freshness - can be inserted and considered to be neurocosmetics. One of the first and oldest coolant ingredients present on the market was menthol and, later, its derivatives [243].

With HydroSal ${ }^{\mathrm{TM}}$ SalCool, SALVONA proposes a patented blend of cooling ingredients that act in a non-competitive way on the skin's different sensory nerve endings, and confer the pleasant sensation without adaptation phenomena [244]. HydroSal ${ }^{\mathrm{TM}}$ SalCool is made of submicron spheres with a diameter of approximately $0.1-0.3 \mu \mathrm{m}$, suitable to enhance the products' delivery to sensory nerves while avoiding bodily cooling. In particular, the slow release of the substances constituting this ingredient is optimized in order to obtain a long-lasting, enhanced, refreshing experience, without skin irritation. Furthermore, as described in SALVONA's brochures, this technology is suitable and safe for all different skin types-even near the eyes [245].

Similarly, GIVAUDAN provided a patented combination of cooling active ingredients in Evercool Skin [246]. In vitro/ex vivo tests demonstrated the activation of the cold sensation receptor TRMP8 (transient receptor potential cation channel, subfamily M, member 8), while in vivo experiments proved a long-lasting cooling effect (also after $120 \mathrm{~min}$ from its application to the skin) using it at $2 \%[47,247,248]$. 


\subsubsection{Soothing Neurocosmetic Products on the Market}

Some neurocosmetic functional ingredients have been used for formulating sensitive skincare products targeted not only to the mass market, but also to beauty centers or spas.

Many examples are presented below:

DOCTOR BABOR Intensive Calming Cream is claimed to soothe the manifestation of neuro-sensitive, extremely sensitive, and very dry skin [249]; it relieves unpleasant feelings of tightness and itching, aiming to obtain an even skin appearance. This product can also be used as a helpful skincare treatment for atopic eczema during symptom-free intervals [249]. The active complex is Neuroxyl, made of gamma-linolenic acid from evening primrose oil, panthenol, and micro silver. Its action reduces irritation and redness and relieves itching. It promotes the regeneration of the skin's natural protective barrier, and improves skin resistance and elasticity $[250,251]$.

Similarly, DOCTOR BABOR Neuro Sensitive Cellular Intensive Calming Cleanser is formulated with a Neuroxyl complex [249]; it is a mild, cleansing milk that replenishes lipids, specifically designed for extremely dry and sensitive skin; it reduces unpleasant itching and pulling sensations, promotes skin barrier regeneration, and improves the skin's smoothness and elasticity [249].

Recently, due to the increased popularity of neurocosmetics, many brands worked to produce professional skincare products available in spas and beauty centers. Zensibia NeoZen Mask, from ISABELLE LANCRAY, is one example; it is a soft leave-on mask that can be applied as a skincare cream, and is particularly indicated for aged, sensitive, and dry skin that presents redness. The Camellia sinensis leaf extract and ceramides contained in Zensibia NeoZen Mask help to repair, reinforce, and protect the skin barrier. If, on the one hand, the contained polyphenols (for example, magnolol), minerals, and micronutrients exhibit antioxidant and anti-inflammatory properties, on the other hand, the probiotic ingredients (Lactobacillus/Arundinaria gigantea ferment filtrate, Leuconostoc/radish root ferment filtrate) ensure healthy skin flora, and activate the skin's natural immune system [252-255].

The neurocosmetic ingredients palmitoyl tripeptide-8 (Neutrazen) and acetyl dipeptide3 aminohexanoate (Bodyfensine by LIPOTEC) work to regenerate skin, reduce redness, and strengthen vein walls for a glowing skin appearance [256,257].

Since sensitive skin needs special precautions, especially regarding the use of specific cosmetic products that should not exacerbate the problems of this imperfection, interested consumers must be reassured in the conscious choice of the products that they will buy, even from a simple reading of the label—especially with regard to neurocosmetics.

\subsection{Neurocosmetic Ingredients for Skin Aging}

Over the years, significant anatomical and physiological changes at the skin level, which progressively decrease skin thickness, elasticity, tone, and chromatic uniformity, are observed. Although the aging process is gradual, skin aging times and methods largely depend on individual characteristics. The nature of the main causes that affect aging are genetic and environmental; for this reason, intrinsic aging and extrinsic aging are distinguished, as well described in the literature [1,258-260].

- Intrinsic (chronological) aging or chrono-aging.

Intrinsic aging is linked to the subject's age; it depends on complex physiological mechanisms involving a series of skin changes (exposed or not to sunlight), and is manifested through a slow process of tissue degeneration. If it is thought of as a phenomenon regarding a single individual, it can occur earlier or later depending on their genetic predisposition, and hormonal levels can influence the thickness of the skin, the quantities of collagen, and its water content. When considering people of the same age and lifestyle, the signs of aging appear more evident in women than in men due to the lower thickness of the female skin, their greater sensitivity to hormones, and their frequent expressiveness of the face. Furthermore, male skin is also richer in sebaceous glands that favor the forma- 
tion of a hydrolipidic film containing more lipids, guaranteeing protection from external agents [261-263].

\section{- Extrinsic aging}

Extrinsic aging is age-independent, and is associated with many features, including life behaviors, diseases, environmental pollution, and sunlight exposure (photo-aging). In particular, smoking, toxic substances, some drugs, and UV rays induce the release of inflammatory mediators, the deactivation of the body's natural defense systems, and the production of free radicals, with a consequent increase in the tendency for the manifestation of aging skin. Photo-aging mainly depends on the individual's skin phototype, sun exposure time, use of sun-care products, and geographical position (by latitude, the sun's rays reach the ground with a different inclination) [261-263].

\subsubsection{Physiological and Morphological Characteristics of Aged Skin}

Among the most frequent phenotypic manifestations of intrinsic and extrinsic aging, there are the onset of wrinkles at different depth levels, hyperkeratosis, reduction in the production of hydrolipidic film (natural moisturizing factor, NMF), and modifications to the dermo-epidermal junction (basal membrane), dermis, hypodermis, and skin appendages. Moreover, melanin distribution is often inhomogeneous, and this favors the formation of dyschromia and hyperpigmentation, especially at the level of the photo-exposed areas $[1,239,264]$.

\subsubsection{Skin Neuro-Aging and Neurocosmetic Ingredients}

Several studies have demonstrated that neuronal cells, like other cellular types, are subject to aging, and this process is known as neurodegeneration [265].

The latter process was deeply investigated, and the role of a neurotoxic peptideamyloid-beta $(A \beta)$-involved in the formation of senile plaques on the surface of nerve endings has been highlighted [266]. This protein is obtained from the proteolytic cleavage of the s-amyloid precursor protein (APP) $[267,268]$. The APP cleavage follows two different enzymatic pathways: the amyloidogenic cleavage pathway, and the non-amyloidogenic pathway. In the first enzymatic process, the $\beta$-secretase enzyme causes the generation of neurotoxic $A \beta$, releasing the N-terminus of $A \beta$ from APP, and a presenilin-dependent $\gamma$-secretase complex releases the $\mathrm{C}$-terminus of $\mathrm{A} \beta$ from the membrane. In an alternative, non-amyloidogenic pathway, APP is processed by the $\alpha$-secretase enzyme, generating an $\mathrm{N}$-terminal fragment (the SAPP $\alpha$ peptide), considered to be a potent neurotrophic factor with neuroprotective properties [269-272].

These two cleavage pathways exist in a balanced manner within a neuronal population that could be considered young. The aging process and oxidative stress lead to a gradual imbalance, in which the neurotoxin becomes dominant, enhancing the neuroaging [271,272]. When exposed to neuro-aging, the messengers released by neurons affect fibroblasts' viability, causing skin aging - neuro-aging promotes fibro-aging $[21,273,274]$. In this research field, studies by CODIF demonstrated that neurons' aging influences the communication between nerves and fibroblasts, decreasing the vitality of collagen, elastin, and fibroblasts, which visibly impacts the skin $[89,261,275,276]$. With this in mind, CODIF developed the active ingredient Neuroguard, which targets the aging of nerve endings by stimulating the $\operatorname{APP} \alpha$ neuroprotector, restoring the features of neurons not exposed to neuro-aging $[275,276]$.

While neurons not exposed to neuro-aging have active synapses, an extensive network, and integral cell nuclei, the neuro-aged ones show fragmented nerve endings, "burntout" nuclei, and a limited network $[275,276]$. In vitro experiments demonstrated that Neuroguard increased soluble amyloid precursor protein alpha production by $87 \%$ within $24 \mathrm{~h}$, protecting the neurons from neurodegeneration $[89,275,276]$. It is possible to say that this ingredient has revolutionized the neurocosmetic world thanks to its mechanism of action [276]. 
Neuroguard is an oligosaccharide composed of guluronic and mannuronic acid, obtained via the enzymatic depolymerization of polysaccharides from the brown algae Laminaria hyperborea and Lessonia nigrescens $[275,276]$. It was developed to re-establish healthy communication between nerves and fibroblasts and regenerate dermal cells weakened by the "messenger of aging" $[265,277,278]$. Thanks to the reactivation of collagen and elastin synthesis, Neuroguard can treat deep wrinkles within 28 days $[275,279-282]$.

As reported in CODIF's brochure, Neuroguard can effectively protect neurons' viability when used both before neuro-aging begins, and when neuro-aging is already in progress $[275,283,284]$.

Another interesting property of this active ingredient is its ability to protect neurons against $\mathrm{H}_{2} \mathrm{O}_{2}$ toxicity ( $42 \%$ of protection). It has been reported that the high presence of free radicals induces a gradual imbalance, more pronounced with age, between the neuroprotector sAPP $\alpha$ and the neurotoxic A $\beta[275,284,285]$. Neuroguard's neuroprotective properties have been studied on both affected and unaffected nerve endings, observing preventive and restorative effects towards fibroblasts and extracellular matrices $[89,265,280]$. Interestingly, by preserving the activity of the fibroblasts from neuro-aging toxicity, the in vitro tests revealed that Neuroguard promoted the expression of genes coding for type III collagen $(+40 \%)$, elastin $(+17 \%)$, syndecan $(+29 \%)$, laminin IV $(+31 \%)$, and extracellular matrix proteins $[27,53]$ Tests performed in vivo showed a $25 \%$ reduction in the volume of crow's feet wrinkles over 56 days for smoother skin $(+11 \%)[89,275,280,281]$.

In summary, in terms of cosmetic benefits, Neuroguard's neuroprotective action prevents neuro-aging by protecting neurons from free radicals' toxicity, stimulates the synthesis of the neuroprotector $\operatorname{sAPP} \alpha$, restores a healthy communication between nerve cells and fibroblasts, protecting dermal cells from aging, and prevents fibro-aging by protecting and reactivating collagen and elastin synthesis [279,286,287].

Neuroguard, especially for mature skin types, provides a specific anti-wrinkle solution, preventing and delaying cellular disorders [276].

Glistin by BIOSIL TECHNOLOGIES is another interesting neurocosmetic functional ingredient that offers an original approach for cellular communication [288]. It is a peptide able to substitute the NGF, favoring nervous cells' survival and development in the epidermis via NGF-like effects [289]. Indeed, while in the skin, nerve cells regulate the activity of all cell types by secreting cytokines, keratinocytes, fibroblasts, and adipocytes, which secrete NGF, ensuring the survival and development of nerve cells. With aging, the metabolism of all skin cells slows down. Keratinocytes, fibroblasts, and adipocytes produce less NGF; thus, nerve cells are unable to support the activities of other cells-especially keratinocytes. Starting from these considerations, a neuroprotection strategy should be adopted, and it should consist of:

- The protection of nerve cells in the epidermis by providing good support for other skin cells;

- The maintenance of good barrier function in order to improve skin hydration (in the epidermis, nervous cells could stimulate the activity of keratinocytes, enhancing the barrier function that, in turn, causes hydrated and protected skin);

- The firming of skin by preserving the lipolytic activity in adipocytes. In the hypodermis, nervous cells stimulated the adipocytes' lipolytic activity, which decreases with aging. By protecting nerve cells, good skin firmness is ensured [290].

Furthermore, it is well known that skin changes exposed to different stresses can lead to a re-organization in the skin's structures and reduce cellular communication, slowing the cutaneous metabolism. In particular, cellular communication is present at all skin levels - in the epidermis, dermis, and hypodermis-enabling cells to assist and support one another. Some exchanges occur between different cell types belonging to the same compartment, or between cells in different compartments. Therefore, it clearly appears essential to maintain these exchanges at all levels.

On these grounds, Glistin offers the solution to the problem, as a functional ingredient that can protect the skin's cellular communication from aging effects, maintain hydration, 
and give maximum comfort. This ingredient was specifically designed to target stem cells in the epidermis, in order to stimulate their proliferation and increase their resistance to UV rays.

Another peptide ingredient provided by BIOSIL TECHNOLOGIES is Glutrapeptide [291]; its action mechanism is focused on cellular communication that involves adipocytes and nerve cells at the hypodermis level. Glutrapeptide supports the activity of adipocytes, and their related ability to eliminate fats by protecting nerve cells [291]. As previously explained, when chronic stress occurs, cortisol levels increase, impacting hypodermis cells. In fact, since cortisol inhibits the production of NGF in adipocytes, neurodegeneration begins. As a result of neurodegeneration, neurons secrete less norepinephrine, which reduces lipolysis (the adipocytes' ability to consume fats), and then adipogenesis (the differentiation of preadipocytes into mature and functional adipocytes) is stimulated.

Stress is thus responsible for the increasing number of adipocytes with a low fatexcretion capacity due to the effects of cortisol. Glutrapeptide's action lies in preventing neurodegeneration by substituting for NGF, promoting the survival and development of nerve cells in the hypodermis by increasing their capacity to excrete fats and inhibiting the effects of cortisol on lipolysis; it is compatible with traditional lipolytic treatments, such as caffeine, for a synergistic effect [290,292].

Rethinking Skin Aging by Modulating Senescence Marker Proteins: The Case of Progerin

For daily life and social wellbeing, the skin's appearance and vitality have primary importance [261-263].

It has been discovered that fighting the signs of aging is not the only strategy to improve skin appearance-the delaying of processes of senescence should also be relevant [293]. Senescence refers to changes that occur in the biology of an organism during the aging process. In particular, the concept of cellular senescence indicates the loss of normal cells' ability to divide, even if the cells are still active. Moreover, an increase in the metalloproteinase activity promoting extracellular matrix degradation arises [294-296].

Senescent cells are also linked to progerin (from the Latin "progeria"; Greek "premature old age"), a toxic protein defined as an "aging biomarker" [297-299].

During the cells' aging process, the amount of progerin increases, inducing nuclear defects, DNA damage, and the appearance of signs of aging [293,298].

Progeline $^{\mathrm{TM}}$ by LUCAS MEYER [300], a three-amino-acid biomimetic peptide (trifluoroacetyl tripeptide-2), was thus developed to improve wrinkles and sagging skin by modulating progerin [301,302]. More specifically, this active compound decreases progerin synthesis and accumulation, and inhibits metalloproteinases [297,303].

In vivo tests performed using a cream containing $2 \%$ Progeline ${ }^{\mathrm{TM}}$ applied to the face and neck, both in the morning and evening, for 56 days, demonstrated how the volume of the jawline decreases [302].

Progeline ${ }^{\mathrm{TM}}$, showing its efficacy on skin slackness and sagging, reduces the appearance of wrinkles and increases skin firmness, elasticity, and viscoelasticity [300]. In other words, Progeline ${ }^{\mathrm{TM}}$ shows several properties: rebuilding collagen matrices, remodeling facial contour lifting, improving skin micro-sculpture and architecture, lifting jawlines, and reducing drooping cheeks [302]. As a final benefit, the skin's flexibility and elasticity are restored.

\section{Cell Communication Supports by Stimulating POMC-Related Receptor Expression}

Carli et al. (2016) reported that an excess of neuropeptides in the absence of receptors could induce the cells' desynchronization. For example, during aging processes in the human epidermis, when the levels of the POMC neuropeptide in the keratinocytes rise, the melanocortin receptor-2 (MC-2R) and micro-opioid receptor 1 (MOR-1) — which are the ACTH and $\beta$-endorphin receptors, respectively-decrease [100,112,304]. Hence, an imbalance of communication between the nervous and skin cells occurs $[89,305]$. 
BASF selected a neurocosmetic ingredient-Achillea millefolium extract, marketed as Neurobiox - able to upregulate receptor expressions [305-307]. The ingredient works for rebalancing communication, with the aim of improving cellular message transmission [89]. BASF evaluated the Achillea millefolium extract's effects on the different epidermal differentiation markers' expression patterns during ex vivo studies performed on normal human skin biopsies [306,307]. The Achillea millefolium extract's properties for smoothing and rejuvenating skin's surface appearance were also evaluated during in vivo studies. The obtained results showed an improved expression of cytokeratin 10, transglutaminase-1, and filaggrin, and an increased epidermal thickness $(+10 \%)$, cohesion, and regeneration $[304,308]$.

Another aspect in which the results of Neurobiox's use are interesting is some skin defects due to intrinsic and extrinsic factors, such as hormones, diet, and stress. Because of these, the skin can develop irregularities and lose its natural glow. To prevent these consequences, attention should be focused on proper skin exfoliation, purification, and regulation of sebum [307].

With this aim, in vivo treatments with $2 \%$ Achillea millefolium extract demonstrated an improved appearance of wrinkles (reduction up to $-14 \%$ ) and pore size (reduction up to $-21 \%)$, compared to placebo, after 2 months of treatment $[89,100,305,307]$.

Thus, pores are visibly refined, and dark spots are reduced for an overall lighter, brighter, smoother, and more radiant skin appearance [307]. Therefore, beyond nerve cell communication, Achillea millefolium extract decrypts, targets, and provides preventive treatment against skin neuro-aging [275].

\section{A Strategy to Combat Dark Spots and Skin Stress}

One of the most common features of aged and photo-exposed skin is pigment spots. Indeed, recent studies demonstrate that skin's cellular stress is an intrinsic factor for forming dark spots. In particular, literature and CODIF studies reported a correlation between the degree of skin innervation, an important release of neuropeptides, and photo-induced skin damage, including pigment spots [180,309,310].

The p53 protein, known as "the stress protein" because its levels increase during cellular stress, shows a critical role for cell survival [311-313]. It was demonstrated that p53 directly regulates POMC expression, which encodes $\alpha-\mathrm{MSH}$, involved in melanogenesis activation [313-315]. Hence, when inhibiting the expression of POMC, melanin's overproduction cannot be triggered, thus preventing the pigment spots [309].

Melanogenesis occurs in melanocytes, and to export the synthesized melanin, they communicate with keratinocytes through their dendrites. Melanocytes are also connected to nerve fibers, which release neuropeptides. When the latter bind to their receptors at the dendrites' surface, these neuropeptides cause melanin synthesis and/or the export to keratinocytes. In detail, the neuropeptide substance P binds to tachykinin receptor 1 (TacR1) - also known as neurokinin 1 receptor (NK1R), or substance P receptor (SPR). TacR1 is placed on the surface of the melanocyte dendrites and activates melanin's export to the upper layers of the skin. If the length of dendrites and the synthesis of substance $\mathrm{P}$ receptors are limited, a reduction in the quantity of melanin exported to the surface of the pigment spots can be enabled [137,309,316].

For this purpose, CODIF has developed Neurolight.61 G-an aqueous extract of Pancratium maritimum, able to reduce the area and the pigmentation of dark spots (up to $-61 \%$ ) by inhibiting both the melanin synthesis induced by stressed keratinocytes and the melanin release triggered by substance $P[279,309]$.

CODIF reported that when Neurolight.61 G is used at $0.33 \%$, it can inhibit POMC expression by $65 \%$, reducing both melanin synthesis $(-73 \%)$ and melanin transfer (by $-62 \%$ ). A $50 \%$ reduction of receptor TacR1 for substance P synthesis was also observed, thus reducing substance P's effects [309]. In vitro tests demonstrated that Neurolight.61 $\mathrm{G}$ could be considered to be a solution for clarifying dark spots' pigmentation without lightening all skin [59], with additional functionality as an anti-aging ingredient [279]. 
The Youth Proteins: KLOTHO and FOXO

FOXO (forkhead box) proteins are a family of transcription factors that play important roles in regulating the gene expression involved in cell growth, proliferation, differentiation, and longevity [84,317-319].

The role of FOXO proteins in cellular protection and longevity to fight aging is well known. In particular, the "nuclear" form of FOXO activates the transcription of the gene involved in cellular detoxification and in repairing DNA damage. When phosphorylated by the AKT (protein kinase B, PKB) factor, FOXO becomes FOXOP and leaves the nucleus for the cytoplasm, where it loses its properties. The AKT factor activation occurs mainly with age, favoring the inactive form FOXOP (Figure 3A) [319].
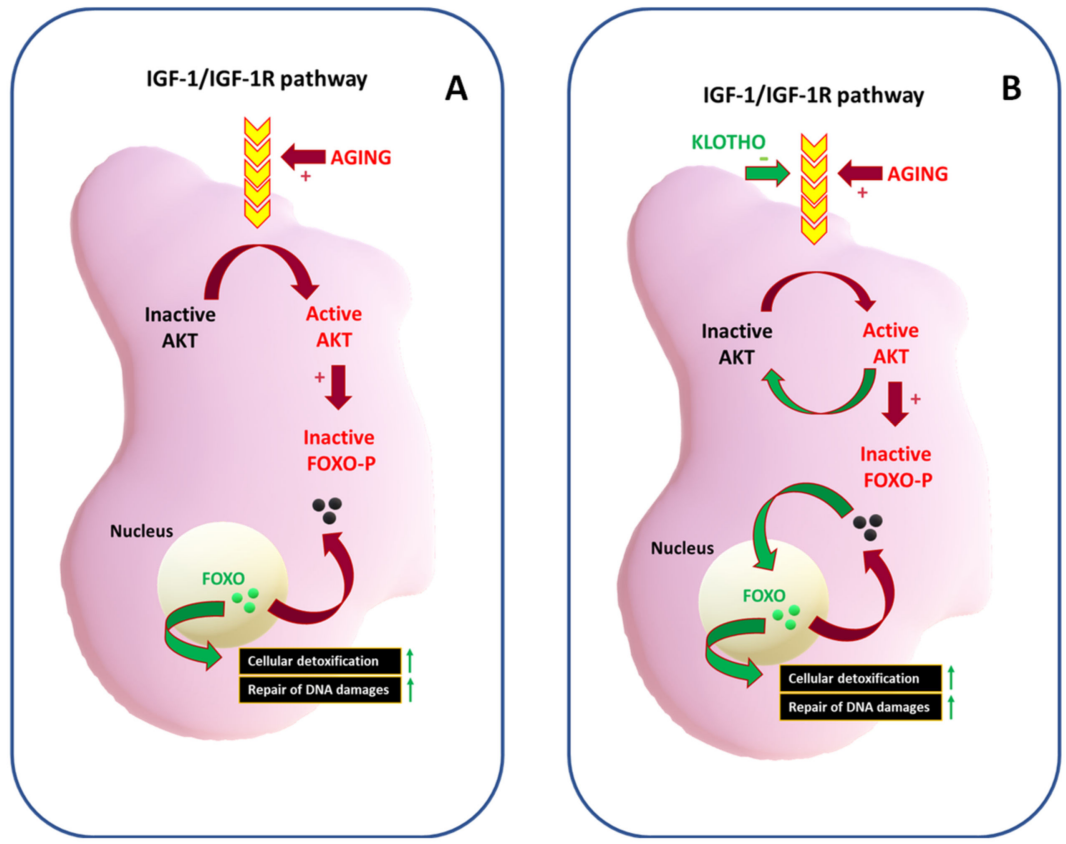

Figure 3. Role of FOXO (A) and KLOTHO (B)

KLOTHO is considered to be the "new youth protein" that slows down aging [320-323], is able to inhibit AKT activation, and maintains FOXO inside the cell nucleus. Its mutation favors the traditional signs of aging, leading to premature death [322-324]. A large number of signaling pathways involve the KLOTHO protein, aiming to restore optimal cellular function (Figure 3B) [322,323].

Unfortunately, the decrease in KLOTHO expression starts from 30 years of age, and the problem worsens with the aging of fibroblasts [322]. Thus, a new strategy to combat skin aging should be devoted to increasing KLOTHO synthesis in fibroblasts.

Recently, the KLOTHO protein has received great attention in cosmetic studies [325]. In this regard, as a result, a liposoluble extract derived from Pistacia lentiscus-a plant native to the Mediterranean region, able to increase the KLOTHO protein synthesis in fibroblasts-has been discovered [326].

Lakesis is the commercial name of a functional ingredient provided by CODIF [327]. In accordance with in vitro test protocol, human dermal fibroblasts from donors of different ages were incubated with Lakesis at $0.005 \%$ for $24 \mathrm{~h}$, observing a $28 \%$ decrease in active AKT levels. By inhibiting the AKT factor, Lakesis lowers the phosphorylation of FOXO, which activates the transcription of detoxification and cellular repair factors in the nucleus. In this case, the predominance of the active form of FOXO was estimated to be $16 \%$. Moreover, the in vitro test demonstrated that Lakesis increases the catalase level—part of the enzymatic pool that detoxifies the cell-by $145 \%$. 
By following in vitro protocol, it was observed that $0.2 \%$ Lakesis, when applied topically for $24 \mathrm{~h}$ to reconstituted human skin, promotes cellular detoxification processes by inhibiting the thioredoxin-interacting protein (TXNIP) (50\% decrease), a thioredoxin inhibitor. Thioredoxin is a powerful antioxidant system widely studied for its involvement in cellular detoxification, and in combating cellular senescence [328,329].

In vitro tests performed on human dermal fibroblasts from donors of different ages showed that Lakesis improves cellular activity, increasing the total amount of cellular RNA and, thus, fronting off the aging process. Indeed, the amount of RNA present inside a cell provides important information about the cellular activity rate, which drops with age. Lakesis, when employed at $0.003 \%$ for treating human dermal fibroblasts for $24 \mathrm{~h}$, improves type I collagen synthesis by $47 \%$. Indeed, in vitro tests performed on 54 -yearold human dermal fibroblasts treated with Lakesis at $0.005 \%$ for five days showed the rejuvenating effect of Lakesis on the extracellular matrix via the reactivation of the synthesis of fibrillin - a major component of elastic fibers-and collagen. In clinical tests, the antiaging effects of Lakesis on the dermis were also evaluated. With twice-daily application of a cream containing $0.2 \%$ Lakesis to the whole face for 28 days, by 20 volunteers aged from 55 to 65 years old, it was shown that Lakesis increased the density of the supporting fibers throughout the dermis, and also ensured their homogeneous distribution. As a result, from consumer analysis, it exhibits anti-aging efficacy on the face. In detail, after Lakesis treatment for 4 weeks, two-thirds of women involved in the studies observed an improvement of facial contours $(+24 \%)$, skin firmness $(+23 \%)$, and skin thickness $(+22 \%)$ [327].

\subsection{Biomimetic Peptides}

As arises from the previous discussion, with the aging of the population and the desire to maintain a young and healthy aspect, the significant development of anti-aging products has been prompted [330]. Interestingly, since 2000, the use of peptides has increased rapidly for a wide range of skincare applications [301,331-333]. This highlights the necessity of acquiring in-depth knowledge of the different molecules and their associated physiological principles [301].

Chemically, peptides are short chains of amino acids linked together by peptide bonds [209]. Instead, in the personal care industry, the term "peptide" refers to molecules that can signal physiological changes at the dermal level or, in some cases, effectively travel into the dermis and compete with neurotransmitter-binding sites to alter physiological activity temporarily [301,331-334]. Today, peptides can be developed or modified in several ways - to improve solubility, to have better penetration, to increase receptor activity, etc. [301]. More specifically, it is better to specify that in the field of research and development of skincare cosmetic formulations, bioactive peptides-also known as biomimetic peptides-are compounds that have an identical amino acid sequence to physiological peptides, but are frequently synthesized biotechnologically $[110,331,332]$. They are becoming increasingly popular for preventing or attenuating the clinical manifestations of damaged and dysfunctional skin, especially during the aging process, hyperpigmentation, and wrinkle development $[35,110]$. Many peptides marketed in cosmetic products as anti-aging, antioxidant, skin-lightening, tissue repairing, soothing and neuromodulating, hair growth controlling, moisturizing, and barrier repair peptide ingredients are claimed to slow down the skin's aging process $[35,209,332]$. Hence, the commercial potential for these molecules appears to be high [301].

Biomimetic peptides play several biological roles, especially as signaling/regulating molecules in a variety of physiological processes (for example, defense, immunity, stress, growth, and homeostasis) [110,333], by mimicking the mechanisms of action and the effects exerted by natural peptides such as growth factors, by interacting with the corresponding receptors and leading to final effects (i.e., slowing of aging) [110,331,335-337].

Several companies, such as PHARMASPECIAL ${ }^{\circledR}$, GALENA $^{\circledR}$, BIOTEC $^{\circledR}$, LIPOTEC $^{\circledR}$, and SILAB ${ }^{\circledR}$, are investing in technologically innovative signal- and neurotransmitter- 
inhibitor peptides particularly indicated as anti-aging ingredients for the formulation of skincare products $[110,303]$.

In recent years, advanced techniques to study molecular structures and extract, isolate, characterize, and synthesize novel molecules have been greatly improved [35,338-340]. Although the process is not complicated or difficult to perform, peptide synthesis, with a defined sequence and high purity ( $>90 \%$ ), can be expensive [209,332,341,342]. In this regard, however, it should be noted that the high efficacy compensates for the cost. In other words, for the formulation of cosmetic products, it is possible to employ these peptides in low amounts [303,343].

Regarding synthetic procedures, usually, as precursors, the standard synthetic process for obtaining peptides to be adopted as cosmetic ingredients utilizes amino acids from plants, fermentation origin, or extracted from certain protein hydrolysates $[36,331,338,340]$. For years, the recombinant production of peptides has also been studied, because it is considered less expensive, but the end products are unlikely to be considered to be as pure as those obtained synthetically. In any case, other synthetic approaches for peptides exist, providing the opportunity to create novel "designed" skincare ingredients [331,338]. Indeed, through the synthesis of peptides, the screening of these virtually endless combinations of amino acid sequences, the optimization of the chemical structure of potential peptide ingredients, their delivery, and their formulation, should open new possibilities for the future of cosmetic ingredients $[331,338,339,344]$.

Another aspect for consideration is the peptide concentration that should be supported by clinical and product-specific studies [332,333]. As a whole, peptides act at extremely low concentrations - generally at the nanomolar level $\left(10^{-9} \mathrm{~mol} / \mathrm{L}\right)$ - because they exhibit a specific activity at a specific target level through a specific binding process [209,331]. Indeed, each peptide sequence shows a highly selective binding affinity that translates into a specific message. The well-known and simplified concept of "key" and "lock" interaction (referring, in this case, to the peptide and receptor, respectively) is used to explain this action. Unfortunately, peptides exhibit a short lifetime in the organism due to the presence of proteolytic enzymes that break their structure to avoid the overload at the target site $[209,332]$. Therefore, the stability of bioactive peptides within a cosmetic formulation is a key feature to ensure active form preservation with the related beneficial effects. The cost/benefit ratio should depend on the ability to use suitable and optimized amino acid sequences intended to maximize the bioactivity and targeted benefits [209,332,333,339,345].

\subsubsection{Topical Peptides and Their Skin Permeability}

Topical peptides can be classified as signals, carriers, enzyme inhibitors, or neurotransmitter inhibitors [110,301,303,335,346].

In detail, signal oligopeptides-also called matrikines-are commonly synthesized from extracellular matrix proteins (EMPs). They boost fibrillogenesis, i.e., they stimulate dermal fibroblasts, with the intent of modulating the EMP network. Furthermore, they increase the levels of collagen, elastin, proteoglycan, glycosaminoglycan (GAG), and fibronectin deposition, causing firmer and younger-looking skin, as do the subclass of carrier peptides [336,344,345,347]. In fact, carrier peptides can be considered a subcategory of signal oligopeptides [336,344]. As an example of this class of topical peptides, it is worth mentioning that Matrixyl (palmitoyl pentapeptide-3) is the first peptide to be formulated in skincare products [301,303,331,332,336,344,345,348,349].

Enzyme inhibitor peptides act directly and indirectly on enzymes, causing cellular anti-aging effects in the dermis, generally ascribed to fibrillogenesis and deposition $[301,303,336,350]$.

Neurotransmitter peptides proteolyze acetylcholine, releasing proteins at the neuromuscular junction - such as SNAP-25, syntaxin-1, and synaptobrevin [110,303,346,348,351]. In detail, the most common peptides that affect the biological function of acetylcholine include acetyl hexapeptide- 3 , pentapeptide- 18 , pentapeptide-3, acetyl octapeptide-3, and tripeptide-3. [303,336,337,344,348,349,352-354]. These peptides can be considered to be 
valid alternatives to botulinum neurotoxin (Botox)—a protein produced by the bacterium Clostridium botulinum (which will be discussed later).

The main difficulty that should be taken into account when peptides are studied is their skin permeability $[224,301,331,335,336,355,356]$, which generally depends on:

- The physicochemical properties of the substance (pKa, molecular size, stability, binding affinity, solubility, and partition coefficient);

- The time necessary for the permeation;

- The integrity, thickness, and components of the skin, and the cutaneous metabolism;

- The site, area, duration of application, and local depot at the site of application.

The ideal parameters for topical peptides are listed below:

- Molecular weight of less than $500 \mathrm{Da}$;

- Moderate log of partition coefficient octanol/water between 1 and 3;

- Melting point less than $200{ }^{\circ} \mathrm{C}$;

- Reasonable aqueous solubility $\left(>1 \mathrm{mg} \mathrm{mL}^{-1}\right)$;

- Zero or few polar centers.

It is worth mentioning that peptides' transdermal penetration is an important parameter to measure the activity and efficacy of topical peptides [301,349,356,357]. In this regard, the superficial layer of the epidermis - the stratum corneum (SC) - provides the first and most rate-limiting barrier for skin permeation by substances [356,358,359].

The SC is a negatively charged tissue, is bound together by tight junctions, and its $\mathrm{pH}$ ranges from 5 to 6 . It is composed of dead corneocytes surrounded by an intercellular lipid layer, and contains structural proteins, water, and lipids. More specifically, the extracellular lipid system, which acts as a protective barrier to maintain skin hydration, contains ceramides, cholesterol, and free fatty acids. Sebum, organic acids, antioxidants, glycerol, GAGs, and inorganic ions are also present at the surface. Molecules' diffusivity through the stratum corneum is related not only to the size of the molecule, but also to the number of hydrogen bonds present in the molecule itself. In detail, the diffusivity is maximal for small, non-hydrogen-bonding molecules, and reaches a minimum when approximately four hydrogen bonds are present. It is necessary for a peptide to cross the cutaneous barrier to reach the viable epidermis (keratinocytes), the basal layer (melanocytes, nerve cell endings), the dermis (fibroblasts), and even the hypodermis (adipocytes) [209,336, 360-362]. However, since peptides and proteins contain many amide bonds (as hydrogen bond donor and acceptor groups), and usually show large molecular size, a low diffusivity in the skin is exhibited [335,362].

Although the topical use of peptides can be considered promising in terms of efficacy, the delivery across the skin could be difficult due to the ionic nature of these materials. Indeed, these peptides are charged at physiological $\mathrm{pH}$, and as a result, they are intrinsically hydrophilic. Thus, the lipophilic stratum corneum represents a barrier to their penetration $[332,335,359]$. Moreover, proteolytic enzymes and the skin's bacterial flora support this barrier in degrading topical peptides [336].

Interestingly, regarding the SC, the skin permeability varies on different parts of the body. However, three main permeation methods can be taken into account for topical drugs: intercellular, transcellular, and transappendageal [360,363,364].

Hydrophobic substances are more permeable in parts of the skin with higher lipid content, such as the face. In contrast, hydrophilic substances permeate more readily in the palms and the soles of the feet, since they contain relatively lower lipid quantities [336].

Lastly, permeation is affected by biological factors, including age, the integrity of the skin, its thickness, and its components, as well as the cutaneous metabolism [336] and the skin type (particularly in the case of dry or aged skin) [262,332,365]. Overall, aged skin contains fewer lipids. Therefore, topical peptides may be more effective in aged people than in younger populations $[262,336]$.

With the advent of more sophisticated software, there is considerably further predictability in estimating a compound's behavior with respect to skin penetration [332]. 
For example, Ham et al. demonstrated that, by simple amino acid substitution, the skin penetration of peptides might be significantly increased [366].

\subsubsection{Delivery Systems for Peptides}

Liposome formulations and colloidal carrier systems are preferred for the dermal delivery of peptides through the epidermal barrier by targeting hair follicles or structurally altering the intercellular lipid network $[335,336,361,367,368]$. An important advantage of the use of liposomal carriers is the ability to protect encapsulated proteins, and deliver to different cell types while avoiding, according to the case, skin toxicity-especially if liposomes are made of epidermal lipids [336,364,369,370].

The delivery efficacy is related to the site and time of the topical protein's application, and to the possibility of creating a local depot at the application site [336,364,371,372].

The use of chemical penetration enhancers might also be valuable $[332,335,342,349,373]$. Another approach to improve delivery is the use of fatty acid derivatives that increase the peptides' lipophilic properties (for example, the palmitoyl derivative) [333,335,336,349,374].

Interestingly, recent studies have discovered good, alternative ways to increase transcutaneous delivery-by using amphiphilic cell penetration peptides (CPP) [374-376], attaching a polyarginine chain to a peptide [377-380], or designing hyaluronic acid (HA) conjugates [379,381] — thus improving peptides' bioactivity and bioavailability [331]. In recent years, other approaches for the transdermal delivery of peptides are gaining popularity, including iontophoresis - which uses small electric currents to enable the passage of charged peptides through the skin - and microdermabrasion, a method that removes some of the layers of the SC in order to improve the absorption of topical peptides, suitable for fine lines and wrinkles [336,355,370,382-385].

Another important aspect that should be taken into consideration, especially from a regulatory and toxicological point of view, is the safety of peptides' use in cosmetic products. In particular, they should be non-immunogenic and non-irritant in order to avoid any side effects $[209,331,332,338]$. Therefore, studies were performed both in vitro and in vivo on the safety of the bioactive peptides.

For example, according to the FDA (Food and Drug Administration), up to 2012, palmitoyl-like peptides have been the most extensively tested molecules, together with the bioactive acetyl hexapeptide-3, whose safety has been evaluated via skin irritation test and patch test $[110,353,354,386,387]$.

In conclusion, new horizons in this field are expected, and some of them suggest the use of functional foods, such as nutritional supplements, as a comprehensive approach to health maintenance [333,338,388-390].

Moreover, since the demand on the personal care market is growing, the manufacturers' competition to guarantee claims about the improvement of the appearance of skin is also increasing [301,303,391]. Research to develop novel ingredients, smart delivery systems, and convenient technologies is a fascinating challenge facing cosmetic manufacturers. It is worth mentioning that despite these formulation challenges, peptides remain the most popular, widely used functional ingredients-especially for anti-aging skincare products.

\subsubsection{Neurotransmitter-Affecting Peptides}

Wrinkles are partially due to excessive stressor stimuli on the facial muscles; unsurprisingly, it is usual to refer to them as "expression lines" [392-394].

From a physiological point of view, the release of a specific neurotransmitter-acetylcholine-allows muscles to contract. This mechanism starts at the presynaptic terminal, where a cascade of protein-protein interactions ends with the fusion of vesicles loaded with acetylcholine to the neuron membrane. In detail, a variation in membrane potential enhances the entry of $\mathrm{Ca}^{2+}$ ions into the neuron. Then, once these ions enter the presynaptic terminal, the release of acetylcholine from the vesicles occurs [301,393]. SNAP-25 (synaptosomalassociated protein 25) - a membrane receptor protein associated with vesicles, involving the SNARE (soluble N-ethylmaleimide-sensitive factor activating protein receptor) complex- 
modulates this process, regulating the binding and fusion of the vesicles $[301,395,396]$. In detail, to form the SNARE complex, Munc-18 (mammalian uncoordinate-18) proteins must bind to syntaxin, followed by SNAP-25 and VAMP (vesicle-associated membrane protein, necessary for the synaptic vesicle's docking and fusion to the presynaptic membrane for the acetylcholine release) [397,398].

Munc-18 proteins are considered important both as components of the synaptic vesicle fusion protein complex, and for exocytosis. This protein directly promotes syntaxin stability by controlling the assembly of core complexes for SNARE-dependent fusion, or by interacting with the SNARE core. In particular, Munc-18a binds to the N-terminal of syntaxin, favoring a conformational change that induces the activation of syntaxin, which in turn connects to the ternary SNARE complex [399].

It has also been reported that proteins belonging to the Munc-18 class bind to the C-terminal of synaptobrevin, suggesting that this type of protein is involved in membrane fusion.

The VAMP protein is linked to a vesicle containing acetylcholine that, after the SNARE complex's formation, fuses with the neuron membrane, inducing the release of acetylcholine into the synaptic space [397,399]. Thus, acetylcholine binds to its receptors on muscle cells, leading to muscle contraction through the release of $\mathrm{Ca}^{2+}$ ions $[301,397,400]$. It is worth mentioning that some synthetic peptides, used for anti-aging cosmetic products, exhibit structural analogies with the sequence present within the SNAP-25 (amino acids 12-17) N-terminal region, and compete with SNAP-25 for the binding sites in the SNARE complex, modulating its formation $[110,301,303,330]$. This structural feature destabilizes the SNARE complex, causing the inhibition of the acetylcholine release and the attenuation of muscle contraction [330].

These kinds of peptides that specifically inhibit neurosecretion, relax muscles, and soften wrinkles are known as neurotransmitter-inhibitor peptides [110,301,338,348,401,402]; pentapeptide-3, acetyl tripeptide-30 citrulline, and pentapeptide- 18 can be considered some examples (see Table 2).

- Pentapeptide-3 (Vialox) is a synthetic peptide derived from snake venom, which acts at the postsynaptic membrane level by following a tubocurarine-like mechanism of action $[301,335,344,348]$. It is a competitive antagonist of the nicotinic acetylcholine membrane receptor [21,403]. Indeed, it prevents the release of sodium ions $\left(\mathrm{Na}^{+}\right)$ required for the depolarization and contraction of muscle fibers, leading to muscle relaxation $[21,335,336]$. Less frequent contractions of muscles result in thinner lines. Softened wrinkles and reduced skin roughness were observed during in vivo and in vitro studies performed for testing this product; the results showed that, after 28 days of twice-daily use, wrinkle depth was reduced by about $49 \%$ [21,335];

- Vanistry ${ }^{\circledR}$, commercialized by Galena and Lipotec [404], is a complex of the bioactive peptides acetyl tripeptide-30 citrulline and pentapeptide-18 [110,404]. If acetyl tripeptide-30 citrulline is a signal peptide [301,335,336], conversely, pentapeptide-18 is a neurotransmitter inhibitor peptide $[335,336,348,405]$. These peptides are used in formulations for wrinkle smoothing, and act synergistically, when applied to the skin, to modulate muscular tension and inhibit matrix metalloproteinases (MMPs) [110,406]. Vanistry $l^{\circledR}$ protects the connective tissue from degradation, and rebuilds ECM and dermal components, conferring to skin the integrity and elasticity needed. Furthermore, it exhibits wound-healing and smoothness effects, and reduces skin tension. In vivo skin surface studies (tightness and drying), color studies, and skin elasticity analysis were performed to demonstrate a visible attenuation of stretch marks when Vanistryl ${ }^{\circledR}$ is used $[110,404,406]$. 
Table 2. Neurotransmitter-affecting peptides ${ }^{1}$.

\begin{tabular}{|c|c|c|c|c|c|c|c|c|c|}
\hline \multicolumn{10}{|c|}{ Neurotransmitter-Affecting Peptides } \\
\hline $\begin{array}{l}\text { Company/ } \\
\text { Supplier }\end{array}$ & Product & $\begin{array}{c}\text { Functionality } \\
\text { Category }\end{array}$ & INCI Name & In vitro/Ex vivo & In vivo & Preservatives & Use Level & $\begin{array}{l}\text { Formulation/ } \\
\text { processing }\end{array}$ & Features \\
\hline DSM & Vialox & $\begin{array}{l}\text { Anti-aging; } \\
\text { anti-wrinkle; } \\
\text { myorelaxant } \\
\text { agent. }\end{array}$ & Pentapeptide-3. & $\begin{array}{l}\text { Competitive antagonist } \\
\text { effect towards the } \\
\text { acetylcholine receptors } \\
\text { coupled with the enkephalin } \\
\text { receptor and closure of the } \\
\text { calcium channels, leading to } \\
\text { muscle relaxation (in vitro); } \\
\text { reduction of muscle } \\
\text { contractions by } 71 \% \text { within } 1 \\
\text { min after treatment, and } 58 \% \\
2 \mathrm{~h} \text { later (in vitro). }\end{array}$ & $\begin{array}{c}\text { Decrease in } \\
\text { wrinkle size } \\
(-49 \%) \text { and skin } \\
\text { roughness }(-47 \%) \\
\text { after } 28 \text { days of } \\
\text { application. }\end{array}$ & None & - & $\begin{array}{c}\text { Powder; } \\
\text { water-soluble. }\end{array}$ & $\begin{array}{c}\text { A topical alternative } \\
\text { to muscle relaxing } \\
\text { injections; } \\
\text { an intensive } \\
\text { treatment for } \\
\text { fighting expression } \\
\text { lines. }\end{array}$ \\
\hline $\begin{array}{l}\text { Galena; } \\
\text { Lipotec }\end{array}$ & Vanistryl & $\begin{array}{l}\text { Firming agent; } \\
\text { delivery } \\
\text { systems/carriers. }\end{array}$ & $\begin{array}{l}\text { Water/aqua (and) } \\
\text { caprylyl/capryl } \\
\text { glucoside (and) } \\
\text { lecithin (and) } \\
\text { glycerin (and) } \\
\text { Pseudoal- } \\
\text { teromonas } \\
\text { ferment extract } \\
\text { (and) acetyl } \\
\text { tripeptide-30 } \\
\text { citrulline (and) } \\
\text { pentapeptide-18 } \\
\text { (and) xanthan } \\
\text { gum (and) } \\
\text { caprylyl glycol } \\
\text { (and) potassium } \\
\text { sorbate (and) } \\
\text { phenoxyethanol. }\end{array}$ & $\begin{array}{l}\text { Inhibition of extracellular } \\
\text { matrix (ECM) degradation } \\
\text { (in vitro); } \\
\text { modulation of acetylcholine } \\
\text { release from neuron cell } \\
\text { cultures by preventing the } \\
\text { entry of } \mathrm{Ca}^{2+} \text { into the neuron: } \\
\text { attenuation of muscle } \\
\text { contraction and relaxation of } \\
\text { the muscle tissue } \\
\text { surrounding striae (in vitro); } \\
\text { increases dermal protein } \\
\text { synthesis: type I collagen } \\
\text { raised to } 128 \% \text {, type IV to } \\
81 \% \text {, and elastin to } 31 \%, \text { in } \\
15 \text { days (in vitro); increases } \\
\text { fibroblast adhesion (125\% in } \\
5 \text { h) and keratinocyte growth } \\
\text { (36\% after } 48 \text { h) (in vitro); } \\
\text { enhancement of wound } \\
\text { healing effect on } \\
\text { keratinocytes (in vitro). }\end{array}$ & $\begin{array}{l}\text { Improvement of } \\
\text { the skin surface, } \\
\text { dryness, and } \\
\text { firmness; decrease } \\
\text { in erythema } \\
(-18 \%) ; \\
\text { attenuation of } \\
\text { stretch marks; } \\
\text { improvement of } \\
\text { the color of stretch } \\
\text { marks. }\end{array}$ & $\begin{array}{l}\text { Phenoxyethanol } \\
\text { (and) potassium } \\
\text { sorbate }\end{array}$ & $5 \%$ & $\begin{array}{l}\text { Liquid; } \\
\text { Water-soluble. } \\
\text { Incompatibilities: } \\
\text { oxidants and } \\
\text { electrophiles. } \\
\text { Processing: } \\
\text { Incorporate in the } \\
\text { aqueous phase in } \\
\text { the final step of } \\
\text { the manufacturing } \\
\text { process. In the } \\
\text { case of emulsion } \\
\text { preparation, it } \\
\text { should be added } \\
\text { once the emulsion } \\
\text { is formed. } \\
\text { Generally, add at a } \\
\text { temperature } \\
\text { below } 40^{\circ} \mathrm{C} ; \\
\text { pH usage range: } \\
4.0-8.0 .\end{array}$ & $\begin{array}{l}\text { Maintenance and } \\
\text { improvement of the } \\
\text { dermal structure; } \\
\text { regeneration of } \\
\text { thethe epidermis, } \\
\text { reconstruction of the } \\
\text { connective tissue by } \\
\text { protecting } \\
\text { and boosting derma } \\
\text { proteins; } \\
\text { increase in skin } \\
\text { elasticity. }\end{array}$ \\
\hline
\end{tabular}


Table 2. Cont

\begin{tabular}{|c|c|c|c|c|c|c|c|c|c|}
\hline \multicolumn{10}{|c|}{ Neurotransmitter-Affecting Peptides } \\
\hline $\begin{array}{l}\text { Company/ } \\
\text { Supplier }\end{array}$ & Product & $\begin{array}{c}\text { Functionality } \\
\text { Category }\end{array}$ & INCI Name & In vitro/Ex vivo & In vivo & Preservatives & Use Level & $\begin{array}{l}\text { Formulation/ } \\
\text { processing }\end{array}$ & Features \\
\hline \multicolumn{10}{|c|}{ Topical peptidomimetic ingredients as alternatives to Botox } \\
\hline Lipotec & Argireline & $\begin{array}{l}\text { Anti-aging; } \\
\text { anti-wrinkle; } \\
\text { myorelaxant } \\
\text { agent. }\end{array}$ & $\begin{array}{l}\text { Aqua/water (and) } \\
\text { acetyl } \\
\text { hexapeptide-8 } \\
\text { (and) caprylyl } \\
\text { glycol. }\end{array}$ & $\begin{array}{l}\text { Modulation of SNARE } \\
\text { complex formation (in vitro); } \\
\text { modulation of catecholamine } \\
\text { release in chromaffin cells } \\
\text { (in vitro). }\end{array}$ & $\begin{array}{c}\text { Reduction of } \\
\text { expression of } \\
\text { wrinkles (volume } \\
\text { by } 20.6 \% \text { and } \\
\text { length by } 15.9 \%) \\
\text { in just } 1 \text { week, } \\
\text { with a solution of } \\
\text { Argireline peptide } \\
(2 \%) .\end{array}$ & None & $\operatorname{Max} 10 \%$ & $\begin{array}{c}\text { Liquid; } \\
\text { water-soluble; } \\
\text { colorless. } \\
\text { Processing: } \\
\text { incorporation at } \\
\text { the final stage of } \\
\text { the manufacturing } \\
\text { process, at a } \\
\text { temperature } \\
\text { below } 40^{\circ} \mathrm{C} . \mathrm{pH} \\
\text { usage range: } \\
3.0-6.0 .\end{array}$ & $\begin{array}{l}\text { Reduction of } \\
\text { wrinkle depth } \\
\text { caused by the } \\
\text { contraction of } \\
\text { muscles of facial } \\
\text { expression, } \\
\text { especially on the } \\
\text { forehead and } \\
\text { around the eyes, } \\
\text { after } 1 \text { week. }\end{array}$ \\
\hline Lipotec & Argirelox & $\begin{array}{l}\text { Anti-aging; } \\
\text { anti-wrinkle; } \\
\text { myorelaxant } \\
\text { agent. }\end{array}$ & $\begin{array}{c}\text { Aqua/water (and) } \\
\text { glycerin (and) } \\
\text { acetyl } \\
\text { hexapeptide-8 } \\
\text { (and) } \\
\text { pentapeptide-18 } \\
\text { (and) citric acid } \\
\text { (and) caprylyl } \\
\text { glycol. }\end{array}$ & $\begin{array}{l}\text { Modulation of glutamate } \\
\text { release (in vitro). }\end{array}$ & $\begin{array}{l}\text { Reduction of } \\
\text { expression lines in } \\
\text { frontal and } \\
\text { periorbital regions, } \\
\text { prolonging the } \\
\text { effects of BoNT-A } \\
\text { even after 6 } \\
\text { months. }\end{array}$ & None & $10 \%$ & $\begin{array}{l}\text { Liquid; } \\
\text { water-soluble. } \\
\text { Incompatibilities: } \\
\text { oxidants and } \\
\text { electrophiles. } \\
\text { Processing: } \\
\text { incorporation in } \\
\text { the aqueous phase } \\
\text { of emulsions and } \\
\text { gels in the final } \\
\text { step of the } \\
\text { manufacturing } \\
\text { process. When } \\
\text { preparing the } \\
\text { emulsion, it } \\
\text { should be added } \\
\text { once the emulsion } \\
\text { is formed at a } \\
\text { temperature } \\
\text { below } 40 \\
{ }^{\circ} \text { C;colorless; } \\
\text { pH usage range: } \\
3.0-8.0\end{array}$ & $\begin{array}{c}\text { Muscle relaxation by } \\
\text { modulating } \\
\text { acetylcholine (ACh) } \\
\text { release; } \\
\text { smoothing effect on } \\
\text { expression lines by } \\
\text { modulating the } \\
\text { SNARE complex } \\
\text { and calcium } \\
\text { channels; reduction } \\
\text { of reappearance of } \\
\text { expression lines in } \\
\text { the crow's feet area. }\end{array}$ \\
\hline
\end{tabular}


Table 2. Cont

\begin{tabular}{|c|c|c|c|c|c|c|c|c|c|}
\hline \multicolumn{10}{|c|}{ Neurotransmitter-Affecting Peptides } \\
\hline $\begin{array}{l}\text { Company/ } \\
\text { Supplier }\end{array}$ & Product & $\begin{array}{l}\text { Functionality } \\
\text { Category }\end{array}$ & INCI Name & In vitro/Ex vivo & In vivo & Preservatives & Use Level & $\begin{array}{l}\text { Formulation/ } \\
\text { processing }\end{array}$ & Features \\
\hline Infinitec & $\begin{array}{l}\text { BONT-L } \\
\text { Peptide } \\
\text { Solution }\end{array}$ & $\begin{array}{l}\text { Anti-aging; } \\
\text { anti-wrinkle; } \\
\text { myorelaxant } \\
\text { agent. }\end{array}$ & $\begin{array}{c}\text { Water/aqua (and) } \\
\text { palmitoyl } \\
\text { hexapeptide-19. }\end{array}$ & $\begin{array}{l}\text { SNARE protein complex } \\
\text { inhibition by } 30 \% .\end{array}$ & $\begin{array}{c}\text { A cream } \\
\text { containing } 5 \% \\
\text { BONT-L Peptide } \\
\text { was tested for } 28 \\
\text { days on } 15 \\
\text { volunteers; an } \\
\text { average reduction } \\
\text { of } 38 \% \text { of } \\
\text { macro-relief of } \\
\text { human skin. }\end{array}$ & Phenoxyethanol & $3-5 \%$ & $\begin{array}{c}\text { Liquid; } \\
\text { water-soluble. }\end{array}$ & $\begin{array}{l}\text { Muscles' relaxation } \\
\text { by minimizing the } \\
\text { release of } \\
\text { acetylcholine, and } \\
\text { consequent wrinkle } \\
\text { reduction, in } 4 \\
\text { weeks. }\end{array}$ \\
\hline Infinitec & $\begin{array}{l}\text { BONT-L } \\
\text { Peptide } \\
\text { Powder }\end{array}$ & $\begin{array}{l}\text { Anti-aging; } \\
\text { anti-wrinkle; } \\
\text { myorelaxant } \\
\text { agent. }\end{array}$ & $\begin{array}{c}\text { Dextran (and) } \\
\text { palmitoyl } \\
\text { hexapeptide-19. }\end{array}$ & $\begin{array}{l}\text { SNARE protein complex } \\
\text { inhibition by } 30 \% \text {. }\end{array}$ & $\begin{array}{c}\text { A cream } \\
\text { containing } 5 \% \\
\text { BONT-L Peptide } \\
\text { was tested for } 28 \\
\text { days on } 15 \\
\text { volunteers; an } \\
\text { average reduction } \\
\text { of } 38 \% \text { of } \\
\text { macro-relief of } \\
\text { human skin. }\end{array}$ & None & $3-5 \%$ & $\begin{array}{c}\text { Powder; } \\
\text { water-soluble. }\end{array}$ & $\begin{array}{l}\text { Muscles' relaxation } \\
\text { by minimizing the } \\
\text { release of } \\
\text { acetylcholine, and } \\
\text { consequent wrinkle } \\
\text { reduction, in } 4 \\
\text { weeks. }\end{array}$ \\
\hline Sederma & Calmosensine & $\begin{array}{l}\text { Anti-Aging; } \\
\text { anti-wrinkle; skin } \\
\text { moisturizer; } \\
\text { soothing agent; } \\
\text { smoothing } \\
\text { agent;cooling } \\
\text { agent. }\end{array}$ & $\begin{array}{c}\text { Butylene glycol } \\
\text { (and) aqua/water } \\
\text { (and) laureth-3 } \\
\text { (and) } \\
\text { hydroxyethyl } \\
\text { cellulose (and) } \\
\text { acetyl dipeptide-1 } \\
\text { cetyl ester. }\end{array}$ & $\begin{array}{l}\text { Stimulation of the release of } \\
\text { pro-endorphins by } \\
\text { keratinocyte; progressive } \\
\text { reduction in muscle } \\
\text { contraction, with levels as } \\
\text { low as } 1 \text { ppm leading to total } \\
\text { muscular inhibition within } 2 \\
\text { h (in vitro). }\end{array}$ & $\begin{array}{l}\text { Modulation of the } \\
\text { cutaneous } \\
\text { perception to } \\
\text { lessen unpleasant } \\
\text { sensations; } \\
\text { reduction of the } \\
\text { perception of heat. }\end{array}$ & None & $3 \%$ & $\begin{array}{c}\text { Liquid; } \\
\text { water-soluble. } \\
\text { Processing: } \\
\text { incorporation at } \\
\text { room temperature. }\end{array}$ & $\begin{array}{l}\text { Enhancement of } \\
\text { skin comfort; } \\
\text { relief of tension to } \\
\text { help prevent the } \\
\text { onset of wrinkles } \\
\text { and expression lines. } \\
\text { Suitable for sensitive } \\
\text { skin }\end{array}$ \\
\hline Lipotec & Inyline & $\begin{array}{l}\text { Anti-aging; } \\
\text { anti-wrinkle; } \\
\text { myorelaxant } \\
\text { agent. }\end{array}$ & $\begin{array}{c}\text { Aqua/water (and) } \\
\text { acetyl } \\
\text { hexapeptide-30 } \\
\text { (and) arginine } \\
\text { (and) caprylyl } \\
\text { glycol. }\end{array}$ & $\begin{array}{l}\text { Reduction of AChR } \\
\text { clustering, a key step in the } \\
\text { post-synaptic functionality } \\
\text { of the neuromuscular } \\
\text { junction (NMJ) (in vitro). }\end{array}$ & $\begin{array}{c}\text { Decrease in } \\
\text { wrinkle depth of } \\
\text { up to } 14.9 \% \text {. }\end{array}$ & None & $5 \%$ & $\begin{array}{c}\text { Liquid; } \\
\text { water-soluble. }\end{array}$ & $\begin{array}{c}\text { Attenuation of } \\
\text { expression wrinkles. }\end{array}$ \\
\hline
\end{tabular}


Table 2. Cont

\begin{tabular}{|c|c|c|c|c|c|c|c|c|c|}
\hline \multicolumn{10}{|c|}{ Neurotransmitter-Affecting Peptides } \\
\hline $\begin{array}{l}\text { Company/ } \\
\text { Supplier }\end{array}$ & Product & $\begin{array}{c}\text { Functionality } \\
\text { Category }\end{array}$ & INCI Name & In vitro/Ex vivo & In vivo & Preservatives & Use Level & $\begin{array}{l}\text { Formulation/ } \\
\text { processing }\end{array}$ & Features \\
\hline Lipotec & Leuphasyl & $\begin{array}{l}\text { Anti-aging; } \\
\text { anti-wrinkle; } \\
\text { myorelaxant } \\
\text { agent. }\end{array}$ & $\begin{array}{l}\text { Aqua/water (and) } \\
\text { glycerin (and) } \\
\text { pentapeptide-18 } \\
\text { (and) caprylyl } \\
\text { glycol. }\end{array}$ & $\begin{array}{l}\text { Modulation of glutamate } \\
\text { release in a neuron cell } \\
\text { culture(in vitro). }\end{array}$ & $\begin{array}{l}\text { Decrease in depth } \\
\text { of expression } \\
\text { wrinkles } \\
(-11.64 \%)\end{array}$ & None & $3-10 \%$ & $\begin{array}{c}\text { Liquid; } \\
\text { water-soluble; } \\
\text { colorless; } \\
\text { pH usage range: } \\
\text { 2.0-5.0.Processing: } \\
\text { incorporation at } \\
\text { the final stage of } \\
\text { the manufacturing } \\
\text { process at a } \\
\text { temperature } \\
\text { below } 40^{\circ} \mathrm{C} \text {. }\end{array}$ & $\begin{array}{l}\text { Reduction of } \\
\text { wrinkle depth } \\
\text { caused by the } \\
\text { contraction of } \\
\text { muscles responsible } \\
\text { for facial expression, } \\
\text { especially in the } \\
\text { forehead and } \\
\text { around the eyes; } \\
\text { has a synergistic } \\
\text { effect with } \\
\text { Argireline. }\end{array}$ \\
\hline Lipotec & Snap 8 & $\begin{array}{l}\text { Anti-aging; } \\
\text { anti-wrinkle; } \\
\text { myorelaxant } \\
\text { agent. }\end{array}$ & $\begin{array}{c}\text { Aqua/water (and) } \\
\text { acetyl } \\
\text { octapeptide-3 } \\
\text { (and) caprylyl } \\
\text { glycol. }\end{array}$ & $\begin{array}{l}\text { Inhibition of SNARE } \\
\text { complex formation (in vitro); } \\
\text { modulation of catecholamine } \\
\text { release in chromaffin cells } \\
\text { (in vitro); } \\
\text { modulation of glutamate } \\
\text { release in a neuron cell } \\
\text { culture (in vitro). }\end{array}$ & $\begin{array}{l}\text { Wrinkle depth } \\
\text { reduction }(63 \%) \text {. }\end{array}$ & None & $3-10 \%$ & $\begin{array}{l}\text { Liquid; } \\
\text { water-soluble; } \\
\text { colorless. }\end{array}$ & $\begin{array}{l}\text { By reducing muscle } \\
\text { contractions, depth } \\
\text { of fine lines and } \\
\text { expression wrinkles } \\
\text { is reduced within } \\
\text { one month of } \\
\text { treatment. }\end{array}$ \\
\hline DSM & Syn-ake & $\begin{array}{c}\text { Anti-aging; } \\
\text { anti-wrinkle; } \\
\text { smoothing agent. }\end{array}$ & $\begin{array}{c}\text { Glycerin (and) } \\
\text { aqua/water (and) } \\
\text { dipeptide } \\
\text { diaminobutyroyl } \\
\text { benzylamide } \\
\text { diacetate. }\end{array}$ & $\begin{array}{l}\text { Reversible antagonist of the } \\
\text { muscular nicotinic } \\
\text { acetylcholine receptor } \\
\text { (mnAChR) (in vitro); } \\
\text { inhibition of the } \mathrm{Na}^{+} \text {uptake } \\
\text { at the postsynaptic } \\
\text { membrane to attenuate } \\
\text { muscle cell contractions } \\
\text { (in vitro); } \\
\text { mimics/mimic waglerin-1 } \\
\text { functionality. }\end{array}$ & $\begin{array}{l}\text { Wrinkle reduction } \\
\text { up to } 52 \% \text { after } 28 \\
\text { days; measurable } \\
\text { smoothing effect } \\
\text { on } 80 \% \text { of the } \\
\text { volunteers; } \\
\text { measurable } \\
\text { wrinkle reduction } \\
\text { on } 73 \% \text { of the } \\
\text { volunteers; } \\
\text { reduction of } \\
\text { wrinkle depth; } \\
\text { smoothing of } \\
\text { crow's feet lines } \\
\text { and forehead } \\
\text { wrinkles. }\end{array}$ & None & $1-4 \%$ & $\begin{array}{c}\text { Liquid; } \\
\text { water-soluble. }\end{array}$ & $\begin{array}{l}\text { Reduction of the } \\
\text { appearance of mimic } \\
\text { wrinkles. }\end{array}$ \\
\hline
\end{tabular}


Table 2. Cont.

\begin{tabular}{|c|c|c|c|c|c|c|c|c|c|}
\hline \multicolumn{10}{|c|}{ Neurotransmitter-Affecting Peptides } \\
\hline $\begin{array}{l}\text { Company/ } \\
\text { Supplier }\end{array}$ & Product & $\begin{array}{c}\text { Functionality } \\
\text { Category }\end{array}$ & INCI Name & In vitro/Ex vivo & In vivo & Preservatives & Use Level & $\begin{array}{l}\text { Formulation/ } \\
\text { processing }\end{array}$ & Features \\
\hline Infinitec & X50 Myocept & $\begin{array}{c}\text { Anti-aging; } \\
\text { anti-wrinkle; } \\
\text { myorelaxant } \\
\text { agent; } \\
\text { cosmetic drone. }\end{array}$ & $\begin{array}{c}\text { Powder form: } \\
\text { lactic } \\
\text { acid/glycolic acid } \\
\text { copolymer (and) } \\
\text { palmitoyl } \\
\text { hexapeptide-52 } \\
\text { (and) } \\
\text { polyvinyl alcohol } \\
\text { (and) } \\
\text { palmitoyl } \\
\text { heptapeptide- } \\
\text { 18.Liquid } \\
\text { suspension: } \\
\text { water/aqua (and) } \\
\text { xanthan gum } \\
\text { (and) lactic } \\
\text { acid/glycolic acid } \\
\text { copolymer (and) } \\
\text { palmitoyl } \\
\text { hexapeptide-52 } \\
\text { (and)polyvinyl } \\
\text { alcohol (and) } \\
\text { palmitoyl } \\
\text { heptapeptide-18. } \\
\text { Additives: } \\
\text { phenoxyethanol } \\
\text { (and) caprylyl } \\
\text { glycol (and) } \\
\text { glycerin (and) } \\
\text { glyceryl caprylate } \\
\text { (and) } \\
\text { phenylpropanol. }\end{array}$ & $\begin{array}{l}\text { Reduction of the entry of } \\
\text { calcium into the neuron, and } \\
\text { inhibition of the formation of } \\
\text { the SNARE protein complex; } \\
\text { reduction of the neuronal } \\
\text { exocytosis. }\end{array}$ & $\begin{array}{l}-20 \% \text { wrinkle } \\
\text { depth and length } \\
\text { reduction in just } 4 \\
\text { weeks. }\end{array}$ & Phenoxyethanol & $1 \%$ & $\begin{array}{l}\text { Powder/liquid } \\
\text { suspension; } \\
\text { water-soluble. }\end{array}$ & $\begin{array}{l}\text { Reduction of the } \\
\text { expression lines. }\end{array}$ \\
\hline
\end{tabular}


Table 2. Cont.

\begin{tabular}{|c|c|c|c|c|c|c|c|c|c|}
\hline \multicolumn{10}{|c|}{ Neurotransmitter-Affecting Peptides } \\
\hline $\begin{array}{l}\text { Company/ } \\
\text { Supplier }\end{array}$ & Product & $\begin{array}{c}\text { Functionality } \\
\text { Category }\end{array}$ & INCI Name & In vitro/Ex vivo & In vivo & Preservatives & Use Level & $\begin{array}{l}\text { Formulation/ } \\
\text { processing }\end{array}$ & Features \\
\hline \multicolumn{10}{|c|}{ Plant extract alternatives to Botox } \\
\hline BASF & Myoxinol & $\begin{array}{c}\text { Anti-aging; } \\
\text { Botox-like agent. }\end{array}$ & $\begin{array}{l}\text { Hydrolyzed } \\
\text { Hibiscus } \\
\text { esculentus extract } \\
\text { (and) dextrin. }\end{array}$ & $\begin{array}{l}\text { Inhibition of muscle cell } \\
\text { contraction; free radical } \\
\text { scavenging. }\end{array}$ & $\begin{array}{c}\text { Wrinkle } \\
\text { smoothening (1\%). }\end{array}$ & None & $0.5-2 \%$ & $\begin{array}{c}\text { Powder; } \\
\text { water-soluble; } \\
\text { insoluble in oils } \\
\text { and fats; } \\
\text { color: beige to } \\
\text { pale yellow; } \\
\text { odor: } \\
\text { characteristic; } \\
\text { pH usage range: } \\
5.0-7.0 \text {. } \\
\text { Processing: } \\
\text { incorporate below } \\
50^{\circ} \mathrm{C} \text { during the } \\
\text { finishing process, } \\
\text { or at room } \\
\text { temperature for } \\
\text { cold processing. }\end{array}$ & $\begin{array}{c}\text { Anti-oxidant; } \\
\text { smooths expression } \\
\text { lines. }\end{array}$ \\
\hline
\end{tabular}


Table 2. Cont

\begin{tabular}{|c|c|c|c|c|c|c|c|c|c|}
\hline \multicolumn{10}{|c|}{ Neurotransmitter-Affecting Peptides } \\
\hline $\begin{array}{l}\text { Company/ } \\
\text { Supplier }\end{array}$ & Product & $\begin{array}{c}\text { Functionality } \\
\text { Category }\end{array}$ & INCI Name & In vitro/Ex vivo & In vivo & Preservatives & Use Level & $\begin{array}{l}\text { Formulation/ } \\
\text { processing }\end{array}$ & Features \\
\hline $\begin{array}{l}\text { Codif } \\
\text { Technologie } \\
\text { Naturelle }\end{array}$ & Stoechiol & $\begin{array}{c}\text { Anti-aging; } \\
\text { anti-wrinkle; } \\
\text { Botox-like agent. }\end{array}$ & $\begin{array}{l}\text { Caprylic/capric } \\
\text { triglyceride (and) } \\
\text { Lavandula } \\
\text { stoechas }\end{array}$ & $\begin{array}{l}\text { Wrinkle relaxation; } \\
\text { stimulation of the division of } \\
\text { keratinocytes in the basal } \\
\text { layer to restore the density } \\
\text { of the epidermis; } \\
\text { promotes the production of } \\
\text { the lipid cement involved in } \\
\text { the restructuring of the } \\
\text { stratum corneum. By } \\
\text { increasing the expression of } \\
\text { the adhesion proteins, } \\
\text { Stoechiol increases the } \\
\text { formation of inter-corneocyte } \\
\text { links, promoting the } \\
\text { reorganization of the } \\
\text { corneocytes and, therefore, } \\
\text { the cohesion of the corneal } \\
\text { layer. Immobilization of the } \\
\text { wrinkle coupled with a } \\
\text { re-densifying and smoothing } \\
\text { effect of the epidermis leads } \\
\text { to a rapid and lasting } \\
\text { reduction in the depth of } \\
\text { expression lines. }\end{array}$ & $\begin{array}{l}\text { Immediate } \\
\text { anti-age effect } \\
\text { from } 0.25 \% . \\
\text { Within just } 1 \mathrm{~h} \text {, the } \\
\text { amplitude of the } \\
\text { cutaneous relief is } \\
\text { smoothed; after } 24 \\
\mathrm{~h} \text { wrinkles are less } \\
\text { visible; } 7 \text { days } \\
\text { after the end of } \\
\text { treatment, } \\
\text { wrinkles are } \\
\text { visibly attenuated. } \\
\text { An immediate } \\
\text { anti-wrinkle } \\
\text { action coupled } \\
\text { with a long-term } \\
\text { anti-age effect that } \\
\text { continues beyond } \\
\text { the end of } \\
\text { treatment. }\end{array}$ & None & $0.25 \%$ & $\begin{array}{c}\text { Liquid; } \\
\text { liposoluble. }\end{array}$ & $\begin{array}{l}\text { Reversible and } \\
\text { repetitive inhibition } \\
\text { of muscle } \\
\text { contractions; } \\
\text { redensifying and } \\
\text { restructuring action } \\
\text { on the epidermis; } \\
\text { immediate and } \\
\text { long-term reduction } \\
\text { in the main wrinkle; } \\
\text { immediate and } \\
\text { long-term } \\
\text { smoothing action on } \\
\text { the roughness of the } \\
\text { skin; decrease in the } \\
\text { expression lines } \\
\text { (visible within } 24 \mathrm{~h} \text { ). }\end{array}$ \\
\hline
\end{tabular}

${ }^{1}$ Abbreviations key: SNARE = soluble N-ethylmaleimide-sensitive factor attachment protein receptor; BoNT-A = botulinum neurotoxin type A; AChR = acetylcholine receptor. 


\subsubsection{Botulinum Neurotoxin: The First Neurotransmitter Inhibitor Anti-Wrinkle Ingredient}

Botulinum toxin is a neurotoxic protein produced by the Clostridium botulinum bacterium [407-410]. Its commercial name is Botox, and it is the most potent known toxin, and one of the most powerful muscle blockers [330,408,411-415].

Structurally, the protein is a disulfide-linked heterodimer constituted by two polypeptidic chains: one at a higher molecular weight ("heavy", $100 \mathrm{kDa}$ ), and the other lighter ("light", 50 kDa) [408,416,417].

The toxin is internalized by receptor-mediated endocytosis after binding to the peripheral neuronal presynaptic membrane, mediated by the heavy polypeptidic chain. After the translocation into the cytoplasm from the endocytic vesicles, the botulinum's lighter chain acts as a protease. It proteolytically cleaves one of the proteins (SNAP-25, synaptobrevin, or syntaxin) of the neuromuscular junction, depending on the neurotoxin's serological subtype. The cleavage of these proteins is an important factor needed for the acetylcholine vesicles' fusion with the inner side of the nerve terminal membrane. Thus, the result is the inhibition of the release of neurotransmitters at neuromuscular junctions [330,408,409,412,413,416,418,419]. According to several studies, one botulinum toxin can inhibit a single neuron. This explains the extraordinary toxicity of this substance.

The inhibition of acetylcholine determines the block of the nerve impulse. Therefore, the botulinum toxin acts by temporarily paralyzing the muscles into which it is injected $[418,419]$. Due to its high toxicity, its use for aesthetic reasons is authorized only in the medical field (i.e., maxillofacial surgery, dermatology, and ophthalmology) [410,415,420,421]. If these injections take place at the facial mimic muscles (responsible for facial expression lines), they can reduce or eliminate this kind of wrinkles, conferring a more youthful appearance to the facial skin $[421,422]$.

However, the risk is high, so many consumers chose to avoid Botox, and started to look for topical, non-injected solutions that mimic its activity $[334,345,423]$.

\subsubsection{Topical Peptidomimetic Ingredients as Alternatives to Botox}

Muscular contractions also perturb the lipid matrix; when muscle contraction is blocked, the lipid matrix maintains its profile, and the skin deformation does not occur, stopping the appearance of wrinkles [301,334].

Several studies are focused on discovering novel functional ingredients as noninvasive alternatives to Botox, focusing the interest especially on peptides that can moisturize, firm, reduce roughness, and smooth wrinkles by interfering with neurosecretion according to different mechanisms [301,330,332,337,344]. Generally, they work to inhibit the release of neurotransmitters involved in muscle contraction indirectly by closing $\mathrm{Ca}^{2+}$ channels $[110,301,344,345,424]$, or by stimulating the release of endogenous messengers (i.e., enkephalins) that induce muscle relaxation [335,405]. Several biomimetic peptides were studied for the interesting properties they display at the level of the dermal structure, where they stimulate fibroblasts to produce collagen, conferring anti-wrinkle and moisturizing benefits on the facial skin [110,209,330,337].

Traditionally, peptides have been produced by partial hydrolysis of proteins of plant or animal origin, in order to obtain mixtures of peptides [36,337,338,343,397].

The cosmetics industry searched for and developed a variety of safer, Botox-like functional ingredients, providing similar and relatively rapid results [301,332,334,344, $348,376]$. Peptides and plant extracts available on the market as alternatives to Botox will be discussed, presenting their mechanisms of action, scientific efficacy, and in vivo experimental results.

An overview of the most used Botox-like functional ingredients is carefully reported in Table 2, with the related useful features for their use.

- Acetyl hexapeptide-3 and -8 - synthetic peptides that, by mimicking the portion of SNAP-25, compete with it for the SNARE complex-were the first Botox-like ingredients brought to market by LIPOTEC, with the trade name Argireline ${ }^{\circledR}[425,426]$. When this analog peptide replaces SNAP-25, the SNARE complex is destabilized, and the 
release of acetylcholine is inhibited, resulting in muscle contraction being significantly reduced $[334,337,353,354]$. It was scientifically demonstrated that Argireline ${ }^{\circledR}$ is a safe, effective anti-wrinkle ingredient $[337,352,427]$, particularly suitable for eye care product formulation $[345,354]$. The results derived from clinical tests showed a wrinkle depth reduction of up to $16.9 \%$ within 15 days, and up to $27 \%$ within 30 days $[395,396]$. For performing these tests, a cream containing 10\% Argireline ${ }^{\circledR}$ was applied twice daily around the eyes by women aged 44 . Moreover, when a cream containing $2 \%$ Argireline ${ }^{\circledR}$ was applied in the periorbital area by women aged $35-45$, a reduction in wrinkle volume (up to $20.6 \%$ ) and length (up to $15.9 \%$ ) was observed within 7 days. An improvement of the skin tone and the presence of fewer wrinkles are the final visible benefits [303,334,335,402];

- Inyline ${ }^{\circledR}$ peptide (Acetyl Hexapeptide-30) by LIPOTEC uses a novel cosmetic approach to reduce muscle contraction and expression wrinkles. It targets the agrin/MuSK postsynaptic pathway, behaving as a competitive antagonist of MuSK (muscle-specific kinase) at the agrin-binding site [428], inactivating the formation of the agrin/MuSK complex and preventing acetylcholine receptor $(\mathrm{AChR})$ clustering-a requirement for triggering muscle contraction [330,429-431]. Agrin is a proteoglycan involved in the organization of the basement membrane architecture [432,433]. A specific form of agrin, released by motor neurons, was mainly studied for developing skeletal muscle fibers; it represents a signal for maintaining the acetylcholine receptors' aggregation, ensuring the neuromuscular junction (NMJ)'s assembly [434,435]. In detail, the agrin, produced by the growing ends of motor neuron axons, binds to MuSK-a tyrosine kinase receptor required for the formation of the neuromuscular junction $[429,430$, $435,436]$. In vitro and in vivo experiments were performed to assess the ability of Inyline ${ }^{\circledR}$ to attenuate expression lines. During in vivo tests, 20 female volunteers aged 41-50 applied a cream containing $5 \%$ Inyline ${ }^{\circledR}$ peptide solution to the crow's feet area twice daily for 28 days. The obtained results showed that the treatment decreased wrinkle depth by $14.9 \%$ [437];

- BONT-L Peptide Solution (palmitoyl hexapeptide-19) is a synthetic Botox-like peptide [438] by INFINITEC [334], able to inactivate SNAP-25 by inhibiting the formation of the SNARE protein complex $[439,440]$. As a result, the release of acetylcholine into the synaptic cleft is prevented [440]. Moreover, an in vivo study on 15 volunteers who used a $5 \%$ cream applied twice daily showed a reduction in periorbital area micro-reliefs of $38 \%$ in 28 days [334];

- Acetyl octapeptide-3, marketed as Snap 8 by LIPOTEC [441], is an elongated sequence of Argireline peptide [303,442]. This analogy allows Snap 8 to mimic SNAP-25 in order to compete effectively in the SNARE complex, obtaining a significant inhibitory effect. It is promoted as the "next-generation" Botox alternative. When used in a 10\% cream applied twice a day for 28 days, a reduction in wrinkle depth around the periorbital area of up to $63 \%$ was observed [334,336,441-443].

Another way to reduce muscular contractions is to prevent or reduce the influx of $\mathrm{Ca} 2+$ ions into the cell-a necessary condition for the fusion of the vesicle containing ACh with the cell membrane, and its release into the synaptic space [334]. As previously discussed, if the Botox equivalents act as competitors with SNAP-25, conversely, other novel ingredients can inhibit the formation of the SNARE protein complex and the vesicle migration by blocking calcium entry [334].

For example, this behavior can be observed for palmitoyl hexapeptide-52 and Pentapeptide-18.

- X50 Myocept by INFINITEC [444] — a blend of palmitoyl hexapeptide-52, lactic acid, glycolic acid, and palmitoyl heptapeptide- 18 - when used at just $0.001 \%$, reduces expression lines around the periorbital area by $20-27 \%$ in 28 days [334];

- Pentapeptide-18 (Leuphasyl) by LIPOTEC mimics the physiological mechanism of enkephalins and, by blocking calcium channels in the neuron, inhibits catecholamine and acetylcholine release $[21,301,405,445]$. As a consequence, the inhibitory G-protein- 
coupled receptor activation occurs with a decrease in the neuronal cell's excitability, preventing the neurotransmitter release [336]. Its Botox-like effects and its safe efficacy were demonstrated, observing the reduction in the depth of fine lines and wrinkles. Moreover, other interesting properties include its hydration ability and improvement of skin firmness and tone $[301,445,446]$. Recently, another aspect was also explored, widening pentapeptide-18 (Leuphasyl)'s cosmetic qualities. Park et al. (2020) modified the commercial anti-aging pentapeptide- 18 by substituting the $\mathrm{N}$ terminal L-tyrosine with D-tyrosine, or adding L/D-tyrosine at the C-terminus. The role in the melanogenesis process was clearly demonstrated, particularly in the case of Leuphasyl peptide analogs containing C-terminal D-tyrosine, adding whitening properties to a remarkable anti-aging cosmeceutical [446]. It was also well proven that pentapeptide-18, when in the presence of acetyl hexapeptide-3, shows a synergistic effect $[110,301,334]$. Many studies showed that a cream containing 5\% Leuphasyl with $5 \%$ Argireline caused a reduction of wrinkles in the periorbital area from $25 \%$ to $47 \%$ within 28 days [334,402];

- Acetyl dipeptide-1 cetyl ester (Calmosensine ${ }^{\mathrm{TM}}$ ), by SEDERMA-a synthetic replica of the naturally occurring peptide in the body-provides an in vitro Botox-like activity for the reversible inhibition of muscle contractions [334,447]. More specifically, it stimulates the release of pro-endorphins by keratinocytes, leading to the stimulation of relaxation messengers in the skin [334]. As a whole, Calmosensine ${ }^{\mathrm{TM}}$ prevents the onset of wrinkles and expression lines by relieving muscular tensions [334,447]. Furthermore, Calmosensine ${ }^{\mathrm{TM}}$ plays an important role in modulating the cutaneous perception of unpleasant sensations - such as heat-improving skin comfort, as confirmed by in vivo studies [303,448]. Another important cosmetic property of the active acetyl dipeptide- 1 cetyl ester is its ability to significantly upregulate epidermal barrier genes, as shown by the results in the work of Khmaladze et al. (2020). [449] Moreover, acetyl dipeptide 1 cetyl ester can significantly reactivate elastogenesis by upregulating some of the most important dermal genes associated with skin wrinkling, such as alpha-1 type I collagen, decorin, lysyl oxidase-like 1, and fibrillin-1. Additionally, it showed interesting anti-glycation activity and promoted proteasomal activity. Thus, acetyl dipeptide 1 cetyl ester is a promising active compound for skincare formulations, especially if an improved barrier function is essential [449].

\subsubsection{Plant Extract Alternatives to Botox}

Alongside Botox-like functional peptide ingredients of both natural and synthetic origins, some extracts derived from plants as further alternatives to muscle relaxants can be used to formulate anti-aging cosmetic products.

Interestingly, CODIF re-discovered the ancestral use of Lavandula stoechas oil—also known as butterfly lavender oil-to provide a relaxing effect on expression lines. They developed and patented Stoechiol [273] — a liposoluble lavender extract obtained via a supercritical $\mathrm{CO}_{2}$ extraction process-as a Botox-like anti-aging ingredient specifically designed for mature skin types [273].

The wrinkle-relaxing strategy proposed using Stoechiol consists of reversible inhibition of muscle contractions for an instantaneous smoothing effect on the cutaneous reliefs, and the restructuring of the epidermis to reduce wrinkles' depth. In fact, over time, the repeated contractions break down the structure of the epidermis and stratum corneum, worsening the already formed furrows. As a result, a loss of epidermal cohesion accelerates the formation of wrinkles and the natural desquamation processes. Cell co-cultures of motor neurons on a monolayer of muscle cells were used to perform in vitro tests to assess the relaxing effect of Stoechiol on their contraction frequency.

It was also shown that Stoechiol stimulates keratinocyte division in the basal layer and promotes the synthesis of the lipid cement by the keratinocytes present in the stratum granulosum. 
Stoechiol helps the reorganization and the cohesion of the corneocytes by increasing the expression of the adhesion proteins of the stratum corneum.

Clinical tests on 20 volunteers aged between 46 and 59 years proved the anti-wrinkle and smoothing efficacy after 7 days of applying $0.25 \%$ or $1 \%$ Stoechiol, twice daily to, the crow's feet area [273].

BASF Care Creations offers Myoxinol ${ }^{\mathrm{TM}}$ [450]—an oligopeptide complex obtained from the native proteins extracted from the seeds of Hibiscus esculentus [451]. It is used to significantly inhibit facial muscle contraction, preventing the formation of crow's feet and nasolabial lines [452,453].

Myoxinol's potential as an anti-wrinkle functional ingredient was firstly assessed by an in vitro test on a co-cultured muscle cell and neuron system. Its ability to inhibit muscle cells' contraction was evaluated by measuring the frequency of contractions over $24 \mathrm{~h}$. These in vitro tests also demonstrated an antioxidant effect, as an additional advantage [454-456].

A clinical test performed involving the application of a cream containing $1 \%$ Myoxinol to the crow's feet area for three weeks suggested that wrinkles became less noticeable-by approximately $26 \%$. The skin appeared lifted and revitalized as final benefits, thanks to a mild exfoliation, an improvement of epidermal thickness, and cohesion [457].

Gatuline Expression by GATTEFOSSÉ is an alternative to Botox based on a plant extract derived from Acmella oleracea, which was standardized to contain the key active constituent, spilanthol [334,458-460].

Due to its Botox-like action, spilanthol inhibits subcutaneous muscle contractions, particularly at the facial level [458,461-465].

In vivo studies revealed that a cream containing $2 \%$ of this extract, when applied twice daily to the crow's feet area, showed results in $75 \%$ of volunteers even during the first day of application. Interestingly, after 20 days of application, a reduction in skin roughness of up to $16 \%$ was evident to the participants [334].

Santana et al. (2011) evaluated the properties of Laricifomes officinalis, rice protein, and glutamic acid as anti-aging ingredients by using neuromuscular preparations. By simulating a Botox-like effect, these components induced a neuromuscular blockade, both individually and in the mixture. A dose-response curve with the mixture was performed to assess these effects [466].

Laricifomes officinalis is a wood-rotting fungus present on coniferous tree trunks in the northern region of China and in the Pacific Northwest of the United States, Canada, and Europe. Vital Especialidades market it as a functional ingredient for anti-aging cosmetic products [466,467].

Generally, rice protein from Oryza sativa L. seeds is considered to be an enzyme inhibitor due to its mechanism of action. It can be used alone as an anti-aging active ingredient. It inhibits matrix metalloprotease activity, and causes hyaluronan synthase 2 gene expression in keratinocytes $[466,468]$.

\subsubsection{In Silico Designed Botox-Like Peptides}

Biomimetic peptides can also be designed in silico; thus, their structures are optimized to find the lowest energy interactions between amino acids and their biological target, necessary for highly specific and efficacious interfacing [339,397,398,469].

Through a randomized screening process, the researchers can test many structurally similar compounds but differ from their constituents. In this way, it is possible to simultaneously evaluate large "libraries" of peptides to identify the most active compound quickly [339]. As a whole, these peptides are usually synthesized in the solid phase to create novel cosmetic ingredients.

Acetyl-hexapeptide-1 is one example [397]; it was synthesized by using the following steps: After the identification of the best amino acid sequence to target pre-synaptic muscle contraction pathways, the acetyl-hexapeptide- 1 was identified as being able to compete with Munc-18 for binding to syntaxin, thus exhibiting a Botox-like activity [397]. 
Interestingly, the results obtained from in vitro efficacy tests showed a reduction of Munc18 /syntaxin binding of up to $37 \%$, consequently reducing acetylcholine release by up to $35 \%$. Furthermore, computational analysis shows the possibility that acetyl-hexapeptide- 1 could have a potential post-synaptic activity, confirmed by in vitro tests. Thus, this peptide binds to the post-synaptic receptors, disrupting the acetylcholine receptor cluster and impeding the $\mathrm{Ca}^{2+}$ release needed for muscle contraction [397].

Acetyl-hexapeptide- 1 can be considered to be the first available ingredient that affects both the pre-and post-synaptic muscle contraction processes, showing a double-action approach corroborated by in vivo studies. Thus, acetyl-hexapeptide- 1 can reduce the expression of wrinkles and lift the labial commissures [397].

From a recent study, it has been demonstrated that Botox-like peptides, usually used as SNARE modulators, could inhibit synaptotagmin 1 (Syt1) [398].

Syt1 is a transmembrane $\mathrm{Ca}^{2+}$ sensor protein located on synaptic vesicles that plays a key role in neurotransmitter release [399]. Indeed, the $\mathrm{Ca}^{2+}$-dependent neurotransmitter release in neurons is strongly inhibited by botulinum neurotoxins (BoNTs), which behave as metalloprotease enzymes able to specifically break down the synaptic proteins required for the neuronal-controlled exocytosis-the plasma membrane protein syntaxin (Syn), the synaptic protein SNAP-25, and the vesicular protein VAMP. As a consequence, the SNARE complex made of these proteins is destabilized, delaying vesicle fusion with the plasma membrane and inhibiting the $\mathrm{Ca}^{2+}$-triggered exocytosis [398,399].

Thus, an interesting approach to reduce wrinkles consists of reducing neuron activity by inhibiting Syt1.

For this purpose, Wongrattanakamon et al. (2018) studied the ability of Botox-like peptides as Syt1 inhibitors by adopting molecular docking and molecular dynamics (MD) simulation investigations in their work [398]. The authors identified the possible binding cleft and mechanism of action, and these findings could represent a starting point for developing novel Botox-like anti-wrinkle molecules that target and modulate Syt1 function. During this work, the Botox-like peptides Argireline, SNAP-8, and Leuphasyl were selected for docking and studied by analyzing the predicted binding energy, the ligand-binding conformation, and the interacting amino acid residue and atom; a good docking affinity to Syt1 was observed. In particular, the authors reported that these Botox-like peptides occupied the binding site area inside Syt1—specifically referring to the C2 domains, C2A and $\mathrm{C} 2 \mathrm{~B}$, which also bind to $\mathrm{Ca}^{2+}$ and synaptic SNARE complexes. The MD simulations showed that these peptides induce Syt1 rigidity by binding to $\mathrm{C} 2 \mathrm{~A}-\mathrm{C} 2 \mathrm{~B}$, which are involved during the conformational change of Syt1from a closed to an open form [398].

However, the next step could focus on designing more selective Botox-like molecules as inhibitors of Syt1, avoiding the occurrence of conformational changes in order to offer safer anti-wrinkle ingredients.

These results should open novel horizons for modulating Syt1 to explore and appropriately characterize the Botox-like molecules' binding sites and their possible mechanism of action [398].

In conclusion, the Botox-like ingredients could provide consumers with the benefits that they desire from using skincare products, without the risks or discomfort associated with the injectable treatments $[344,410]$.

\section{Anti-Aging Neurocosmetic Formulations on the Market}

In recent times, many cosmetic companies have tried to bring their innovative neurocosmetic product lines to market, both as regards formulation technologies and ingredients, intending to offer benefits to consumers in short timeframes.

In general, consumers' demands focus on innovative cosmetic products that are safe, effective, and of high quality. Hence, industries have tried to meet those demands [470,471].

Moreover, each cosmetic product on the market must conform to the current legislation of the country or countries where the cosmetic is marketed, in order to guarantee quality, efficacy, and safety [472,473]. 
It is necessary to demonstrate that:

- $\quad$ All ingredients are safe after testing their toxicity in vitro, ex vivo, and in vivo [29,473];

- All ingredients are compatible with one another and with their packaging as the finished formulation. Consequently, to assess this aspect, it is necessary to carry out stability studies on the end product in the chosen final pack [474,475];

- The active ingredients do not claim any therapeutic effect on the skin [29];

- The packaging is aesthetically attractive and safe;

- All information about the products labeled on the packaging is clear for consumers [476];

- $\quad$ End products are also pleasant and have an adequate cost-benefit ratio.

A significant challenge for the marketing of the manufacturing companies is how cosmetic products can be portrayed, as well as finding the right way to communicate to consumers the innovations related to a novel functional ingredient present in the cosmetic product's formulation, its effectiveness, the product's use, or innovative packaging [476].

Regarding innovative active ingredients, ARKANA [477] —a modern brand from Poland-represents an example, proposing a series of interesting active polypeptide ingredients, some of which are described in the following.

- Suitable for mature skin types, Bo2Look Therapy MD estetic serum, elixir, and wrinkle relaxer are formulated with the patented neuropeptide $\mathrm{XEP}^{\mathrm{TM}}-018[478,479]$. The latter is a non-invasive anti-aging ingredient alternative to Botox, indicated for smoothing mimic wrinkles by relaxing facial muscles [480]. The main component of this formulation is the Mu-conotoxin CnIIIC, a synthetic biomimetic peptide inspired by that of venomous marine cone snail (Conus consors) [442,480-483]. This peptide blocks both voltage-gated sodium channels (Nav 1.4) and nicotinic acetylcholine receptors $(\mathrm{nAChR})$, performing its action as a neuromuscular transmission modulator [442,480,483-486]. It instantly relaxes expression wrinkles when used for formulating a cosmetic product, giving a smooth skin appearance. In fact, in vivo studies conducted on 33 volunteers using a product containing 3\% XEP-018 showed a visible reduction in wrinkle depth and rugosity $2 \mathrm{~h}$ after a single application [480,483,487];

- NEURO GABA\&NANA THERAPY MD serum, cream, peel, and neuro gaba lift mask consist of a combined lifting and peeling instant treatment that contains GABA (gamma-aminobutyric acid) and NANA (N-acetyl-5-neuraminic acid) neurotransmitters, and lactic acid [488]. The smoothing of furrows and improvement of skin tension ("freezing effect"), immediate filling of wrinkles ("plumping effect"), and skin moisturization ("hydro effect") are the ensured visible effects. When low- and highmolecular-weight hyaluronic acid is added, it deeply and long-lastingly moisturizes the skin, fills wrinkles, and makes the skin firm and flexible [489].

The action performed by the combination of the ingredients indicates that GABA relaxes muscles, soothes the skin, repairs cellular damage, promotes hyaluronic acid and collagen synthesis, and reduces wrinkles [490,491], while NANA promotes collagen and elastin regeneration by preventing their degradation, as well as reducing wrinkles [492]. Lactic acid, beyond the ability to enhance the other functional ingredients' penetration, makes the skin flexible, moisturizes it, and stimulates the production of ceramides that seal the lipid barrier $[13,493,494]$. This intense lifting treatment is particularly indicated for mature skin types [489].

- Carbo V Re-Constructor Serum, Carbo V Elixir, and Carbo V Re-Constructor-noninvasive "home care" treatments with effects similar to carboxytherapy-combine XIMILENE $^{\circledR}$ (ethyl ximenynate), arginine, and PROGELINE ${ }^{\mathrm{TM}}$-a remodeling peptideas an alternative to thread lifts [495-498].

Ximenynic acid and arginine improve microcirculation, promote skin oxygenation, stimulate collagen production, and increase skin nourishment to make skin firm [340,499_ 503]. PROGELINE ${ }^{\mathrm{TM}}$ boosts these effects by restoring and improving the facial oval shape in the "V" zone, reinforcing collagen and elastin fibers, firming and lifting the skin, and eliminating double chin, flabby skin, and jowls [297,302,303]. 
- Biomimetic Therapy PRO line is an intense home care treatment for mature skin types that prevents and reduces the signs of aging. This product, thanks to the presence of Progeline $^{\mathrm{TM}}$, Adipofill' ${ }^{\mathrm{TM}}{ }^{\mathrm{TM}}$, and hyaluronic acid, is proposed for the loss of defined face contour, skin laxity, and drooping eyelids. It improves skin elasticity and flexibility, firms, and lifts wrinkles [504].

LUCAS MEYER COSMETICS produces another interesting formulation containing modern active ingredients, with the trade name Adipofill' in $^{\mathrm{TM}}$ [505-507].

Adipofill' $^{\mathrm{TM}}{ }^{\mathrm{TM}}$ is a patented neurocosmetic functional ingredient containing an LOrnithine amino acid biotechnologically obtained from vegetable starch and encapsulated in an Ionosome ${ }^{\mathrm{TM}}$ delivery system. It mimics the lipohormesis phenomenon (an adaptive response of the adipose tissue to micro-stress exposure) by activating the gene expression of the transcription factor HIF- $1 \alpha$ (hypoxia-inducible factor 1- $\alpha$ ), affecting the activation of adipogenesis (transformation of pre-adipocytes into adipocytes), the activation of lipogenesis (triglyceride synthesis), and the inhibition of lipolysis (the breakdown of lipids into free fatty acids) [508-513]. In particular, since Adipofill' ${ }^{\mathrm{TM}}{ }^{\mathrm{T}}$ lowers the free fatty acid release from adipocytes, it induces triglyceride storage, provoking adipocyte swelling, i.e., increase in size. Therefore, by inducing the refilling of cell fat with the increases in fatty tissue volume, the result mimics the cosmetic surgery effect of lipofilling. Clinical tests demonstrated that Adipofill' ${ }^{\mathrm{TM}}{ }^{\mathrm{M}}$, with its non-invasive and bio-controlled mechanism, combats age-related lipoatrophy, improving the signs of aging-such as nasogenian fold depth, skin smoothness, and roughness, causing a plumper and more youthful look [508].

Generally, as reported by Rattan (2013), if referring to the aging process, hormesis can be defined as the beneficial effects derived from the cellular response after stimuli by physical, chemical, and biological stressors-i.e., irradiation, pro-oxidants, exercise, etc.resulting in the improvement of cells, tissues, organs, and organisms' physiology [514].

Moreover, several studies reported in the literature show that many foods' components are responsible for positive effects on human health [514,515].

For this reason, these ingredients started to be used for the formulation of different anti-aging skincare cosmetic products [514,515].

As for the formulation of cosmetics more suitable for delivering the active ingredient to the target, it is necessary to consider various parameters, such as the skin type or the desired aesthetic effect.

The anti-age treatments can be formulated to meet different needs, depending on the type of effect (protective/preventive and restorative/soothing, in case of the first and most evident accentuated aging signs, respectively), and be made suitable for different skin types. Indeed, melting emulsions, for example, with their rich and comfortable after-feel, are preferred for dry/very dry skin, while light-textured products with an evanescent skin-feel are preferred for combination/oily skin.

Therefore, the most common cosmetic forms-the O/W (oil in water) or W/O (water in oil) emulsions-are applied differently.

Today, anti-aging creams can also be formulated with sunscreen ingredients, differentiating daily and night treatments.

Usually, a cream treatment is often proposed in combination with the concentrated serum, which must be applied first, with the aim of enhancing the derived benefits [471].

\section{Neurocosmetics: What about Regulation?}

In our society, as it emerges from several surveys and web sources, loyalty and transparency - the best premises for safety and efficacy—are fundamental for each product [516-519].

In the Cosmetic Regulation (EC) 1223/2009, it can be read: "The consumer should be protected from misleading claims concerning efficacy and other characteristics of cosmetic products. In particular, Directive 2005/29/EC of the European Parliament and of the Council of 11 May 2005 concerning unfair business-to-consumer commercial practices in the internal market is applicable. 
Furthermore, the Commission, in cooperation with the Member States, should define common criteria in relation to specific claims for cosmetic products." [15].

Considering the high number of cosmetic products available on the EU market, it is very important to offer specific, understandable, and reliable information, substantiated by using generally accepted methods, to enable consumers to make informed choices and compare products to find the ones that best suit their needs [15].

This is the aim of the report provided by the European Commission about cosmetic claims and advertising, which are considered essential tools necessary to inform consumers about the qualities and characteristics of each cosmetic product $[15,520]$.

Through the label present on the packaging, consumers are informed about the product and its features. Therefore, the ingredients, its use, period after opening (PAO), storage, beneficial effects, claims, warnings, etc. must be reported [476,521-525]. Moreover, product claims are also used by cosmetic companies to differentiate their products from competitors; thus, the claim should contribute to stimulating innovation and competition among companies [15,526,527].

For cosmetic products' claims that meet their purposes adequately, it is important to have a well-organized framework that ensures that these claims are fair and do not mislead consumers when considering the context and the marketing tools (printed material, a TV advertisement, or the use of new media such as the internet or smartphones) in which such claims are shown [15,527].

To respect social, linguistic, and cultural diversity, a flexible approach for communicating the messages to end users should be followed. Indeed, the marketing communications should be clear, precise, relevant, and understandable by the target audience [527].

For this purpose, competent authorities tasked with market surveillance must be able to easily verify all claims based on harmonized common criteria at the EU level [15].

As reported in the CTPA Guide to Cosmetic Advertising Claims (2018), the Cosmetic Products Regulation (EC) No 1223/2009 and (EU) Commission Regulation No 655/2013 on Common Criteria for Claims introduced particular and specific requirements about claims for cosmetic products [471].

The claims must conform to the Common Criteria and be legally compliant, truthful, supported by evidence, honest, fair, and allow informed decision-making by consumers [471].

The measures provided by Regulation (EC) No 1223/2009 agree with the Standing Committee on Cosmetic Products' opinion. However, it should be considered that the common criteria should be applied only to products defined as cosmetic products according to Article 2 of Regulation (EC) No 1223/2009. A gap of knowledge should be resolved with the aim of defining the attribution of each product to a certain category. For example, there is a concrete risk that products are wrongly considered cosmetics when, in fact, they are medical devices or medicines [15].

Hence, the Member States agree on a case-by-case basis whether a product can be considered a cosmetic or not [15].

After defining neurocosmetics and their action mechanisms in the previous paragraphs, and cosmetic products according to Article 2 of Regulation (EC) 1223/2009, some doubts may arise regarding the fact that in order for the cosmetic to carry out its functions, it is "intended to be placed in contact with the external parts of the human body" [528-530], while for neurocosmetics the place of action does not seem clear.

In general, to exploit their action, the neurocosmetic ingredients should pass through the dermis - the layer just below the epidermis; thus, starting from these preliminary considerations, some questions arise:

How could we define neurocosmetics?

Should this feature lead us to think of neurocosmetics as drugs?

Should they be considered as "borderline products"?

As for the United States, it is too early to determine the Food and Drug Administration's position in this regard. The current difference between cosmetics, quasi-drugs, and 
pharmaceutical products makes it difficult for the manufacturing ingredient companies to make progress, in a short time, in the neurocosmetic field.

Everything depends on what is declared both on the label—especially from the claims point of view-and when the product must be advertised (example: anti-stress, massage action, aromatherapy in the case of a particular neurocosmetic fragrance, even if the "aromatherapy" is improperly defined as neurocosmetics).

By considering the definition of a cosmetic product according to Article 2 of Regulation (EC) 1223/2009 [531], "a substance or mixture intended to be ingested, inhaled, injected or implanted into the human body should be not considered a cosmetic product" [532]; there is a clear difference both for products intended to be applied to different sites or for product uses that go beyond the cosmetic sphere.

Indeed, sometimes, it may not be entirely clear whether a given product is a cosmetic within the meaning of Regulation (EC) 1223/2009, or if it falls under other regulations. In the case of these products defined as "borderline products", the classification decision must be made on a case-by-case basis. A case-by-case evaluation of the product's featuresincluding absorption, concentration, route of administration, frequency of application, application site, and the degree of penetration, if considering the delivery pathway-should be carried out by the competent national authority in order to decide the product qualification. For example, it often happens that products—such as hair regrowth products-are incorrectly classified as cosmetics. To harmonize the qualification of the products across the Single Market, and to determine whether the product falls within the definition given in Article 2 [527], several guidance documents have been produced by the European Commission about the delimitation between cosmetic products and other product categories, e.g., medicines (governed by legislation Medicinal Products Directive 2001/83/EC) [533], biocidal products (governed by Biocidal Products Regulation 528/2012) [534], or medical devices (governed by EU Regulation on Medical Devices 745/2017) [535].

The European Commission has published guidance documents to facilitate the application of the legislation in these cases, publishing the borderline manual for cosmetic products (Manual of the Working Group on Cosmetic Products (Sub-Group on Borderline Products) on the scope of application of the Cosmetics Regulation (EC) No 1223/2009 [531].

This manual is updated periodically with the addition, for example, of other categories or practical examples. Thus, the manual of borderline products helps to answer the question: "is this product a cosmetic or does it fall under other regulations?" [531]. The latest update was published in February 2020, and it is related to version 5.1 [536].

However, it is worth mentioning that, as indicated in the text of the manual, it is not legally binding, and does not represent an official document of the European Commission. It should be interpreted more as an orientation manual - a practical collection of examples to be applied case-by-case that can support both cosmetic industries and competent authorities [536].

The manual is based on three aspects related to cosmetics:

- Product type;

- Application site;

- Cosmetic purpose.

An example that can be found in this manual concerns anti-wrinkle cosmetic products:

Specifically, the question is: "are anti-wrinkle products cosmetics?". As a whole, antiwrinkle products can be cosmetic products if they are mentioned in Regulation (EC) No 1223/2009 [15]. However, some products presented as anti-wrinkle that can restore, correct, or significantly modify physiological functions by exercising a pharmacological, immunological, or metabolic action would not qualify as cosmetics [536].

The regulation will continue to support the innovations in anti-age skincare products.

There is still much to learn about the skin and topical applications of functional cosmetic ingredients. 
Today, it is difficult to harmonize the regulation of cosmetic products globally; indeed, for example, compliance with Chinese regulation represents a limiting problem for novel functional ingredients.

What may be possible in the near future for topical skincare?

\section{Conclusions}

As B. Carli (2017) wrote, how we feel inside is reflected by how we look outside [334].

Today, science's progress helps to improve the appearance and wellbeing of skin, particularly with the benefits offered by using neurocosmetic ingredients.

Since the information about the definition of neurocosmetics is often confused, especially by the marketing field, this review has been focused on the concept of neurocosmetics, highlighting the importance of the ancestral biological and physiological connection between skin and brain; an outline on psychosomatics better explains this link.

An overview of the neurosciences and their applications in the cosmetic field, particularly related to cosmetic product pleasantness, is described.

Technical information (i.e., company/supplier, physico-chemical characteristics, functionality categories, recommended use level, formulation/processing, claim ideas, benefits, proven efficacy demonstrated by in vitro, ex vivo, and in vivo tests, compliances) on marketed neurocosmetic ingredients in skincare products-mainly targeted for anti-aging cosmetic treatments-has been reported. The cosmetic products' regulatory status and the importance of the safety assessment of cosmetics to guarantee their quality, efficacy, and safety have been evidenced. More specifically, the challenge for neurocosmetics is to formulate ideal multitasking products, suitable for each consumer's skin type, while respecting their anatomical and physiological assets (hormonal and genetic factors, skin thickness, age, skin complexion), without forgetting to analyze their behaviors (smoking) or environmental exposure (extrinsic factors). Thus, new and interesting advances are presented as a great opportunity for cosmetic companies. The next step of this emerging trend is the innovation in researching and developing new methodologies, strategies, and techniques to formulate cosmetic products that will allow the discovery of a new world of benefits and claims.

Consumers are excited about new experiences that can introduce them to an unconventional beauty routine that also meets their requests in lowering the associated costs.

Author Contributions: Conceptualization, J.G. and V.R.; methodology, V.R.; validation, V.R., J.G., and P.F.; formal analysis, P.C.; resources, J.G. and P.C.; writing-original draft preparation, J.G.; writing-review and editing, P.C. and V.R.; supervision, P.C.; project administration, P.C. All authors have read and agreed to the published version of the manuscript.

Funding: This research received no external funding.

Conflicts of Interest: The authors declare no conflict of interest.

\section{References}

1. Bovero, A. Dermocosmetologia Dall'inestetismo al Trattamento Cosmetico, 1st ed.; Tecniche Nuove: Milano, Italy, 2011; ISBN 978-88481-2626-7.

2. Niedziela, M. Designing (Neuro) cosmetics for healthy mind, healthy body. Househ. Pers. Care Today 2019, 14, $21-22$.

3. Valéry, P. L'Idée Fixe ou Deux Hommes à la Mer; Collection Blanche; Gallimard, 1933; p. 172. (French Edition).

4. McGlone, F.; Reilly, D. Sensitive skin and the somatosensory system, 2nd Edition. In Cosmetic Dermatology: Products and Procedures; Draelos, Z.D., Ed.; Wiley-Blackwell: Oxford, UK, 2016; pp. 38-46, ISBN 978-1-4051-8635-3.

5. Chamberlin, C.M.; Peschard, O.; Mondon, P.; Lintner, K. Quantifying Skin Relaxation and Well-Being. Cosmet. Toilet. Mag. 2004, $119,65-70$.

6. Roosterman, D.; Goerge, T.; Schneider, S.W.; Bunnett, N.W.; Steinhoff, M. Neuronal Control of Skin Function: The Skin as a Neuroimmunoendocrine Organ. Physiol. Rev. 2006, 86, 1309-1379. [CrossRef]

7. Pincelli, C.; Bonté, F. The 'beauty' of skin neurobiology. J. Cosmet. Dermatol. 2003, 2, 195-198. [CrossRef] [PubMed]

8. Lafrance, M. From the Skin Ego to the Psychic Envelope: An Introduction to the Work of Didier Anzieu BT-Skin, Culture and Psychoanalysis; Cavanagh, S.L., Failler, A., Hurst, R.A.J., Eds.; Palgrave Macmillan: London, UK, 2013; pp. 16-44, ISBN 978-1-13730004-1. 
9. Misery, L. Les nerfs à fleur de peau. Int. J. Cosmet. Sci. 2002, 24, 111-116. [CrossRef] [PubMed]

10. França, K.; Lotti, T.M. Psycho-Neuro-Endocrine-Immunology: A Psychobiological Concept BT_Ultraviolet Light in Human Health, Diseases and Environment; Ahmad, S.I., Ed.; Springer International Publishing: Cham, Switzerland, 2017; pp. 123-134, ISBN 978-3-319-56017-5.

11. Lombardi, S.A.; Ratti, A. Neurocosmesi, psicocosmesi e neuroscienze: Cosa sono? Kosmet. Numer. Due 2019, 40-42. Available online: https: / / www.bregaglio.eu/2018/09/18/neurocosmesi-psicocosmesi-e-neuroscienze-cosa-sono/ (accessed on 14 July 2021).

12. Boulais, N. The epidermis: A sensory tissue. Eur. J. Dermatol. 2008, 18, 119-127. [CrossRef] [PubMed]

13. Pillai, S.; Manco, M.; Oresajo, C. Epidermal Barrier. In Cosmetic Dermatology: Products and Procedures, 2nd Edition; Draelos, Z.D., Ed.; Wiley-Blackwell: Hoboken, NJ, USA, 2016; pp. 3-12, ISBN 978-1-118-65546-7.

14. Ramos-e-Silva, M.; Celem, L.R.; Ramos-e-Silva, S.; Fucci-da-Costa, A.P. Anti-aging cosmetics: Facts and controversies. Clin. Dermatol. 2013, 31, 750-758. [CrossRef] [PubMed]

15. EUR-Lex Access to European Union Law Consolidated Text: Regulation (EC) No 1223/2009 of the European Parliament and of the Council of 30 November 2009 on Cosmetic Products (Recast) (Text with EEA Relevance) Text with EEA Relevance. Available online: https: / / eur-lex.europa.eu/legal-content/EN/TXT/?uri=CELEX\%3A02009R1223-20201203 (accessed on 17 May 2021).

16. Ahsan, $\mathrm{H}$. The biomolecules of beauty: Biochemical pharmacology and immunotoxicology of cosmeceuticals. J. Immunoass. Immunochem. 2019, 40, 91-108. [CrossRef] [PubMed]

17. U.S. Food \& Drug Administration Is It a Cosmetic, a Drug, or Both? (Or Is It Soap?). Available online: https: / / www.fda.gov/ cosmetics/cosmetics-laws-regulations/it-cosmetic-drug-or-both-or-it-soap\#Definecosmetic (accessed on 10 May 2021).

18. Surber, C.; Kottner, J. Skin care products: What do they promise, what do they deliver. J. Tissue Viability 2017, 26, 29-36. [CrossRef]

19. Bom, S.; Jorge, J.; Ribeiro, H.M.; Marto, J. A step forward on sustainability in the cosmetics industry: A review. J. Clean. Prod. 2019, 225, 270-290. [CrossRef]

20. EUR-Lex Access to European Union Law Report From the COMMISSION to the European Parliament and the Council on Product Claims Made Based on Common Criteria in the Field of Cosmetics COM/2016/0580 Final. Available online: https: / / eur-lex.europa.eu/legal-content/EN/TXT/?uri=COM:2016:0580:FIN (accessed on 17 May 2021).

21. Husein el Hadmed, H.; Castillo, R.F. Cosmeceuticals: Peptides, proteins, and growth factors. J. Cosmet. Dermatol. 2016, 15, 514-519. [CrossRef]

22. Morganti, P.; Coltelli, M.-B. A New Carrier for Advanced Cosmeceuticals. Cosmetics 2019, 6, 10. [CrossRef]

23. Draelos, Z.D. Cosmetics, categories, and the future. Dermatol. Ther. 2012, 25, 223-228. [CrossRef]

24. Misery, L. Neuro-immuno-cutaneous system (NICS). Pathol. Biol. 1996, 44, 867-874.

25. Theoharides, T.C.; Stewart, J.M.; Taracanova, A.; Conti, P.; Zouboulis, C.C. Neuroendocrinology of the skin. Rev. Endocr. Metab. Disord. 2016, 17, 287-294. [CrossRef] [PubMed]

26. Misery, L. Skin, immunity and the nervous system. Br. J. Dermatol. 1997, 137, 843-850. [CrossRef]

27. Fatemi, S.A.; Jafarian-Dehkordi, A.; Hajhashemi, V.; Asilian-Mahabadi, A. Biomimetic proopiomelanocortin suppresses capsaicininduced sensory irritation in humans. Res. Pharm. Sci. 2016, 11, 484-490. [CrossRef] [PubMed]

28. Global Cosmetic Industry. The Beauty Innovator's Resource Chemical Reaction: Neurocosmetics. Available online: https: / / www.gcimagazine.com/business/rd/technology/7333696.html (accessed on 17 May 2021).

29. Lintner, K.; Mas-Chamberlin, C.; Mondon, P.; Peschard, O.; Lamy, L. Cosmeceuticals and active ingredients. Clin. Dermatol. 2009, 27, 461-468. [CrossRef] [PubMed]

30. Morganti, P.; Chen, H.-D.; Gao, X.-H.; Gazzaniga, G.; Morganti, L. Natural Ingredients for advanced neurocosmetics. Pers. Care 2013, 6, 19-24.

31. Wanninger, A. Well-being with Neurocosmetics? Available online: https://www.cossma.com/ingredients/article/well-beingwith-neurocosmetics-36213.html (accessed on 12 May 2021).

32. Karashima, Y.; Damann, N.; Prenen, J.; Talavera, K.; Segal, A.; Voets, T.; Nilius, B. Bimodal Action of Menthol on the Transient Receptor Potential Channel TRPA1. J. Neurosci. 2007, 27, 9874-9884. [CrossRef]

33. Deckner, G. Cool Off or Warm Up with Neurocosmetics. Available online: https://knowledge.ulprospector.com/10629/pcc-cooloff-or-warm-up-with-neurocosmetics / (accessed on 12 May 2021).

34. Kamatou, G.P.P.; Vermaak, I.; Viljoen, A.M.; Lawrence, B.M. Menthol: A simple monoterpene with remarkable biological properties. Phytochemistry 2013, 96, 15-25. [CrossRef] [PubMed]

35. Gazitaeva, Z.I.; Drobintseva, A.O.; Chung, Y.; Polyakova, V.O.; Kvetnoy, I.M. Cosmeceutical product consisting of biomimetic peptides: Antiaging effects in vivo and in vitro. Clin. Cosmet. Investig. Dermatol. 2017, 10, 11-16. [CrossRef] [PubMed]

36. Zappelli, C.; Barbulova, A.; Apone, F.; Colucci, G. Effective Active Ingredients Obtained through Biotechnology. Cosmetics 2016, 3, 39. [CrossRef]

37. Juliano, C.; Magrini, G.A. Cosmetic Functional Ingredients from Botanical Sources for Anti-Pollution Skincare Products. Cosmetics 2018, 5, 19. [CrossRef]

38. Dias, R.; Oliveira, H.; Fernandes, I.; Simal-Gandara, J.; Perez-Gregorio, R. Recent advances in extracting phenolic compounds from food and their use in disease prevention and as cosmetics. Crit. Rev. Food Sci. Nutr. 2021, 61, 1130-1151. [CrossRef] [PubMed] 
39. Pinkas, A.; Gonçalves, C.L.; Aschner, M. Neurotoxicity of fragrance compounds: A review. Environ. Res. 2017, 158, 342-349. [CrossRef]

40. Dhanjal, D.S.; Bhardwaj, S.; Sharma, R.; Bhardwaj, K.; Kumar, D.; Chopra, C.; Nepovimova, E.; Singh, R.; Kuca, K. Plant Fortification of the Diet for Anti-Ageing Effects: A Review. Nutrients 2020, 12, 3008. [CrossRef]

41. Niedziela, M.M. Thoughtful packaging: Using applied consumer neuroscience to see what the consumer sees. Househ. Pers. Care Today 2016, 11, 14-16.

42. Niedziela, M.M.; Ambroze, K. Chapter 17-Neuroscience tools: Using the right tool for the right question. In; Meiselman, H.L.B.T.-E.M., Ed.; Woodhead Publishing: Sawston, UK, 2021; pp. 559-592, ISBN 978-0-12-821125-0.

43. Frick, R. Happy Cosmetics: The Trend That Reconnects Beauty to Life? Available online: https://www.premiumbeautynews com/en/happy-cosmetics-the-trend-that,16680 (accessed on 10 May 2021).

44. KENZO Lotus Blanc. Available online: https://www.kenzoparfums.com/gb/en/white-lotus/ (accessed on 12 May 2021).

45. KENZO Serum in a Mask KENZOKI WHITE LOTUS. Available online: https://www.kenzoparfums.com/gb/en/skincare/ skincare-femme/kenzoki-lotus-blanc/serum-in-a-mask/K30400016.html (accessed on 17 May 2021).

46. Tungmunnithum, D.; Kongsawadworakul, P.; Hano, C. A Cosmetic Perspective on the Antioxidant Flavonoids from Nymphaea lotus L. Cosmetics 2021, 8, 12. [CrossRef]

47. Furrer, S.M.; Slack, J.P.; McCluskey, S.T.; Ungureanu, I.M.; Daniher, A.T.; Blancher, G.; Bell, K.; Krawec, P.; Cole, L.; Gray, K. New Developments in the Chemistry of Cooling Compounds. Chemosens. Percept. 2008, 1, 119-126. [CrossRef]

48. Oh, S.-H.; Yu, J.-J.; Kim, H.-J.; Oh, K.-W.; Eun, J.-S. Effects of white lotus extracts on sleeping, chloride influx, and oxidation. Food Sci. Biotechnol. 2011, 20, 949. [CrossRef]

49. Cosmetics \& Toiletries Euphoryl Omega-3. Available online: http://dir.cosmeticsandtoiletries.com/detail/tradeName.html?id= 19492 (accessed on 17 May 2021).

50. Saengsorn, K.; Jimtaisong, A. Determination of hydrophilic-lipophilic balance value and emulsion properties of sacha inchi oil. Asian Pac. J. Trop. Biomed. 2017, 7, 1092-1096. [CrossRef]

51. Penagos-Calvete, D.; Duque, V.; Marimon, C.; Parra, D.M.; Restrepo-Arango, S.K.; Scherf-Clavel, O.; Holzgrabe, U.; Montoya, G.; Salamanca, C.H. Glycerolipid Composition and Advanced Physicochemical Considerations of Sacha Inchi Oil toward Cosmetic Products Formulation. Cosmetics 2019, 6, 70. [CrossRef]

52. Soimee, W.; Nakyai, W.; Charoensit, P.; Grandmottet, F.; Worasakwutiphong, S.; Phimnuan, P.; Viyoch, J. Evaluation of moisturizing and irritation potential of sacha inchi oil. J. Cosmet. Dermatol. 2020, 19, 915-924. [CrossRef] [PubMed]

53. Corradi, I.; De Souza, E.; Sande, D.; Takahashi, J.A. Correlation Between Phenolic Compounds Contents, Anti- tyrosinase and Antioxidant Activities of Plant Extracts. Chem. Eng. Trans. 2018, 64, 109-114. [CrossRef]

54. PresseBox Euphoryl(TM) Omega -3 LS 9846-Naturally Enhances Beauty and Well-Being. Available online: https://www. pressebox.com/inactive/basf/Euphoryl-TM-Omega-3-LS-9846-naturally-enhances-beauty-and-well-being/boxid/258069 (accessed on 17 May 2021).

55. Lombardi, S.A.; Ratti, A. Emotional effects induced by lip balms containing different emollients: Neuroscientific approach to studying the tactual experience. Househ. Pers. Care Today 2017, 12, $42-47$.

56. De Tollenaere, M.; Meunier, M.; Scandolera, A.; Sandre, J.; Lambert, C.; Chapuis, E.; Auriol, D.; Reynaud, R. Well-aging: A new strategy for skin homeostasis under multi-stressed conditions. J. Cosmet. Dermatol. 2020, 19, 444-455. [CrossRef] [PubMed]

57. Denda, M. Epidermis as the "Third Brain"? Dermatol. Sin. 2015, 33, 70-73. [CrossRef]

58. Personal Care Creating Skin Wellbeing by Dopamine Stimulation. Available online: https://www.personalcaremagazine.com/ story /5507/ creating-skin-wellbeing-by-dopamine-stimulation (accessed on 12 May 2021).

59. Bousquet, M.; Saint-Pierre, M.; Julien, C.; Salem, N., Jr.; Cicchetti, F.; Calon, F. Beneficial effects of dietary omega-3 polyunsaturated fatty acid on toxin-induced neuronal degeneration in an animal model of Parkinson's disease. FASEB J. 2008, 22, $1213-1225$. [CrossRef] [PubMed]

60. Sgoifo, A.; Carnevali, L.; Pattini, E.; Carandina, A.; Tanzi, G.; Del Canale, C.; Goi, P.; De Felici del Giudice, M.B.; De Carne, B.; Fornari, M.; et al. Psychobiological evidence of the stress resilience fostering properties of a cosmetic routine. Stress 2021, 24, 53-63. [CrossRef] [PubMed]

61. Berke, J.D. What does dopamine mean? Nat. Neurosci. 2018, 21, 787-793. [CrossRef] [PubMed]

62. Global Cosmetic Industry. The Beauty Innovator's Resource Happy Talk is Serious Science. Available online: https://www. gcimagazine.com/business/rd/ingredients/Happy-Talk-is-Serious-Science-574289811.html (accessed on 17 May 2021).

63. Effegilab The Era of Psycho-Cosmetics. Available online: https://effegilab.com/en/lera-della-psico-cosmesi/ (accessed on 17 May 2021).

64. Giannakakis, G.; Grigoriadis, D.; Giannakaki, K.; Simantiraki, O.; Roniotis, A.; Tsiknakis, M. Review on psychological stress detection using biosignals. IEEE Trans. Affect. Comput. 2019, 1. [CrossRef]

65. Chojnowska, S.; Ptaszyńska-Sarosiek, I.; Kępka, A.; Knaś, M.; Waszkiewicz, N. Salivary Biomarkers of Stress, Anxiety and Depression. J. Clin. Med. 2021, 10, 517. [CrossRef]

66. Pössel, P.; Ahrens, S.; Hautzinger, M. Influence of cosmetics on emotional, autonomous, endocrinological, and immune reactions. Int. J. Cosmet. Sci. 2005, 27, 343-349. [CrossRef] [PubMed] 
67. Cosmetics Business Active Ingredient Neurophroline Blocks Stress Hormone to Control Skin. Available online: https: //cosmeticsbusiness.com/news/article_page/Active_ingredient_Neurophroline_blocks_stress_hormone_to_control_skin/12 0025 (accessed on 17 May 2021).

68. Researchgate Study of the Application and Validation of the Ethological Coding System for Interviews (ECSI). Available online: https:/ / www.researchgate.net/publication/287225071_Study_of_the_application_and_validation_of_the_Ethological_ Coding_System_for_Interviews_ECSI (accessed on 15 May 2021).

69. Paas Oliveros, L.K.; Villanueva Valle, J.; González Arredondo, S.I.; Fresán, A.; Arango de Montis, I.; Brüne, M.; Muñoz Delgado, J. Study of the Application and Validation of the Ethological Coding System for Interviews (ECSI). Available online: http:/ / www.revistasaludmental.mx/index.php/salud_mental/article/view/SM.0185-3325.2015.005 (accessed on 15 May 2021).

70. Gabriel, D.; Merat, E.; Jeudy, A.; Cambos, S.; Chabin, T.; Giustiniani, J.; Haffen, E. Emotional Effects Induced by the Application of a Cosmetic Product: A Real-Time Electrophysiological Evaluation. Appl. Sci. 2021, 11, 4766. [CrossRef]

71. Dunn, J.H.; Koo, J. Psychological Stress and skin aging: A review of possible mechanisms and potential therapies. Dermatol. Online J. 2013, 19, 18. [CrossRef]

72. Fink, G. Stress: Definition and History. In Stress Science: Neuroendocrinology; Fink, G., Ed.; Academic Press: Oxford, UK, 2009; pp. 3-9, ISBN 9780123785718.

73. Chen, Y.; Lyga, J. Brain-Skin Connection: Stress, Inflammation and Skin Aging. Inflamm. Allergy Drug Targets Former. Curr. Drug Targets Inflamm. Allergy 2014, 13, 177-190. [CrossRef]

74. Kimyai-Asadi, A.; Usman, A. The Role of Psychological Stress in Skin Disease. J. Cutan. Med. Surg. 2001, 5, 140-145. [CrossRef]

75. Folkman, S. Stress: Appraisal and Coping BT_Encyclopedia of Behavioral Medicine; Gellman, M.D., Turner, J.R., Eds.; Springer: New York, NY, USA, 2013; pp. 1913-1915, ISBN 978-1-4419-1005-9.

76. Antonelli, M.; Donelli, D. Effects of balneotherapy and spa therapy on levels of cortisol as a stress biomarker: A systematic review. Int. J. Biometeorol. 2018, 62, 913-924. [CrossRef]

77. Dixon, L.J.; Witcraft, S.M.; McCowan, N.K.; Brodell, R.T. Stress and skin disease quality of life: The moderating role of anxiety sensitivity social concerns. Br. J. Dermatol. 2018, 178, 951-957. [CrossRef] [PubMed]

78. Givaudan Neurophroline ${ }^{\circledR}$ Overall Skin Stress Control. Available online: https://www.givaudan.com/fragrance-beauty/activebeauty/products/neurophroline (accessed on 17 May 2021).

79. Hellhammer, D.H.; Wüst, S.; Kudielka, B.M. Salivary cortisol as a biomarker in stress research. Psychoneuroendocrinology 2009, 34, 163-171. [CrossRef]

80. Evers, A.W.M.; Verhoeven, E.W.M.; Kraaimaat, F.W.; De Jong, E.M.G.J.; De Brouwer, S.J.M.; Schalkwijk, J.; Sweep, F.C.G.J.; Van De Kerkhof, P.C.M. How stress gets under the skin: Cortisol and stress reactivity in psoriasis. Br. J. Dermatol. 2010, 163, 986-991. [CrossRef] [PubMed]

81. Choe, S.J.; Kim, D.; Kim, E.J.; Ahn, J.-S.; Choi, E.-J.; Son, E.D.; Lee, T.R.; Choi, E.H. Psychological Stress Deteriorates Skin Barrier Function by Activating 11ß-Hydroxysteroid Dehydrogenase 1 and the HPA Axis. Sci. Rep. 2018, 8, 6334. [CrossRef]

82. Maarouf, M.; Maarouf, C.L.; Yosipovitch, G.; Shi, V.Y. The impact of stress on epidermal barrier function: An evidence-based review. Br. J. Dermatol. 2019, 181, 1129-1137. [CrossRef]

83. Tia, N.; Singh, A.K.; Pandey, P.; Azad, C.S.; Chaudhary, P.; Gambhir, I.S. Role of Forkhead Box O (FOXO) transcription factor in aging and diseases. Gene 2018, 648, 97-105. [CrossRef] [PubMed]

84. Tsitsipatis, D.; Klotz, L.O.; Steinbrenner, H. Multifaceted functions of the forkhead box transcription factors FoxO1 and FoxO3 in skin. Biochim. Biophys. Acta Gen. Subj. 2017, 1861, 1057-1064. [CrossRef] [PubMed]

85. Meyrignac, C.; Plaza, C.; Capallere, C.; Botto, J. 263 Effect of environmental stress combined with "daily life stress" on skin aging. J. Investig. Dermatol. 2019, 139, S259. [CrossRef]

86. Botto, J.; Meyrignac, C.; Plaza, C.; Lequoy, V.; Oger, E.; Coquet-Morel, C.; Capallere, C. 636 Effect of daily life stress on skin aging-Development of 3D skin reconstructed models. J. Investig. Dermatol. 2018, 138, S108. [CrossRef]

87. DSM BEL-EVEN ${ }^{\circledR}$ Future-Proof Your Skin from the Effects of Daily Stress. Available online: https://www.dsm.com/personalcare/en_US/products/skin-bioactives/bel-even.html (accessed on 17 May 2021).

88. Imfeld, D.; Jackson, E.; Seroul, P. Inhibition of cutaneous cortisol activation: A novel approach to protect skin from stress induced damage and aging. 30th IFSCC Congr. 2018, S1-S501. Available online: https://www.researchgate.net/publication/327816215_ Inhibition_of_cutaneous_cortisol_activation_A_novel_approach_to_protect_skin_from_stress_induced_damage_and_aging (accessed on 14 July 2021).

89. Carli, B. Feeling good about neuro-cosmetics. Househ. Pers. Care Today 2016, 11, 9-11.

90. Schmelz, M.; Paus, R. Opioids and the skin: "Itchy" perspectives beyond analgesia and abuse. J. Investig. Dermatol. 2007, 127, 1287-1289. [CrossRef]

91. Bigliardi, P.L.; Tobin, D.J.; Gaveriaux-Ruff, C.; Bigliardi-Qi, M. Opioids and the skin-Where do we stand? Exp. Dermatol. 2009, 18, 424-430. [CrossRef] [PubMed]

92. Bigliardi, P.L.; Dancik, Y.; Neumann, C.; Bigliardi-Qi, M. Opioids and skin homeostasis, regeneration and ageing-What's the evidence? Exp. Dermatol. 2016, 25, 586-591. [CrossRef] [PubMed]

93. Bigliardi-Qi, M.; Bigliardi, P.L.; Eberle, A.N.; Büchner, S.; Rufli, T. $\beta$-Endorphin Stimulates Cytokeratin 16 Expression and Downregulates $\mu$-Opiate Receptor Expression in Human Epidermis. J. Investig. Dermatol. 2000, 114, 527-532. [CrossRef] 
94. Bigliardi, P.L.; Büchner, S.; Rufli, T.; Bigliardi-Qi, M. Specific Stimulation of Migration of Human Keratinocytes by $\mu$-Opiate Receptor Agonists. J. Recept. Signal Transduct. 2002, 22, 191-199. [CrossRef] [PubMed]

95. Wintzen, M.; Gilchrest, B.A. Proopiomelanocortin, Its Derived Peptides, and the Skin. J. Investig. Dermatol. 1996, 106, 3-10. [CrossRef] [PubMed]

96. Luger, T.A. Neuromediators-a crucial component of the skin immune system. J. Dermatol. Sci. 2002, 30, 87-93. [CrossRef]

97. Luger, T.A.; Scholzen, T.; Brzoska, T.; Becher, E.V.A.; Slominski, A.; Paus, R. Cutaneous Immunomodulation and Coordination of Skin Stress Responses by $\alpha$-Melanocyte-Stimulating Hormonea. Ann. N. Y. Acad. Sci. 1998, 840, 381-394. [CrossRef] [PubMed]

98. Mazurkiewicz, J.E.; Corliss, D.; Slominski, A. Spatiotemporal Expression, Distribution, and Processing of POMC and POMCderived Peptides in Murine Skin. J. Histochem. Cytochem. 2000, 48, 905-914. [CrossRef] [PubMed]

99. Yardman-Frank, J.M.; Fisher, D.E. Skin pigmentation and its control: From ultraviolet radiation to stem cells. Exp. Dermatol. 2020, 30, 560-571. [CrossRef] [PubMed]

100. Pain, S.; Dezutter, C.; Reymermier, C.; Vogelgesang, B.; Delay, E.; André, V. Age-related changes in pro-opiomelanocortin (POMC) and related receptors in human epidermis. Int. J. Cosmet. Sci. 2010, 32, 266-275. [CrossRef] [PubMed]

101. Yeo, H.; Ahn, S.S.; Lee, Y.H.; Shin, S.Y. Regulation of pro-opiomelanocortin (POMC) gene transcription by interleukin-31 via early growth response 1 (EGR-1) in HaCaT keratinocytes. Mol. Biol. Rep. 2020, 47, 5953-5962. [CrossRef]

102. Slominski, A.; Wortsman, J. Neuroendocrinology of the Skin. Endocr. Rev. 2000, 21, 457-487. [CrossRef] [PubMed]

103. Pondeljak, N.; Lugović-Mihić, L. Stress-induced Interaction of Skin Immune Cells, Hormones, and Neurotransmitters. Clin. Ther. 2020, 42, 757-770. [CrossRef]

104. Slominski, A.; Zbytek, B.; Zmijewski, M.; Slominski, R.M.; Kauser, S.; Wortsman, J.; Tobin, D.J. Corticotropin releasing hormone and the skin. Front. Biosci. 2006, 11, 2230-2248. [CrossRef]

105. Luger, T.A.; Paus, R.; Slominski, A.; Lipton, J. The Proopiomelanocortin System in Cutaneous Neuroimmunomodulation: An Introductory Overview. Ann. N. Y. Acad. Sci. 1999, 885, xi-xiv. [CrossRef] [PubMed]

106. Slominski, A.T.; Botchkarev, V.; Choudhry, M.; Fazal, N.; Fechner, K.; Furkert, J.; Krause, E.; Roloff, B.; Sayeed, M.; Wei, E.; et al. Cutaneous Expression of CRH and CRH-R: Is There a "Skin Stress Response System?". Ann. N. Y. Acad. Sci. 1999, 885, $287-311$. [CrossRef] [PubMed]

107. Mibelle Group Biochemistry Happybelle-PE Phyto-endorphins for a Youthful Glow. Available online: https://mibellebiochemistry com/happybelle-pe (accessed on 12 May 2021).

108. Prospector Happybelle-PE. Available online: https://www.ulprospector.com/en/eu/PersonalCare/Detail/2249/66038 /Happybelle-PE (accessed on 17 May 2021).

109. Schmidt, D.; Zülli, F. Role of Beta-Endorphin in the Skin. SÖFW J. 2005, 131, 1-4.

110. Lima, T.N.; Moraes, C.A.P. Bioactive Peptides: Applications and Relevance for Cosmeceuticals. Cosmetics 2018, 5, 21. [CrossRef]

111. Schmid, D.; Belser, E.; Zülli, F. Self-tanning Based on Stimulation of Melanin Biosynthesis. Cosmet. Mag. 2007, 122, 55-62.

112. Carli, B. Calm Down! Available online: https:/ / search.informit.org/doi/10.3316/informit.409457987624542 (accessed on 17 May 2021).

113. Sunar, K.; Kumar, U.; Deshmukh, S.K. Chapter 12-Recent Applications of Enzymes in Personal Care Products; Dhillon, G.S., Kaur, S.B.T.-A.-I.W. as F. for E.P., Eds.; Academic Press: San Diego, CL, USA, 2016; pp. 279-298, ISBN 978-0-12-802392-1.

114. Zahid, H.; Rizwani, G.H.; Ishaqe, S. Phytopharmacological Review on Vitex agnus-castus: A Potential Medicinal Plant. Chin. Herb. Med. 2016, 8, 24-29. [CrossRef]

115. Webster, D.E.; Lu, J.; Chen, S.-N.; Farnsworth, N.R.; Wang, Z.J. Activation of the $\mu$-opiate receptor by Vitex agnus-castus methanol extracts: Implication for its use in PMS. J. Ethnopharmacol. 2006, 106, 216-221. [CrossRef]

116. Piazzini, V.; Monteforte, E.; Luceri, C.; Bigagli, E.; Bilia, A.R.; Bergonzi, M.C. Nanoemulsion for improving solubility and permeability of Vitex agnus-castus extract: Formulation and in vitro evaluation using PAMPA and Caco-2 approaches. Drug Deliv. 2017, 24, 380-390. [CrossRef] [PubMed]

117. Joyderm La Neurocosmesi Polisensoriale. La Nuova Frontiera Della Cosmesi. Available online: https://www.joyderm.it/ neurocosmesi/ (accessed on 9 May 2021).

118. Charles Dorni, A.I.; Amalraj, A.; Gopi, S.; Varma, K.; Anjana, S.N. Novel cosmeceuticals from plants-An industry guided review. J. Appl. Res. Med. Aromat. Plants 2017, 7, 1-26. [CrossRef]

119. Li, Y.; Pham, V.; Bui, M.; Song, L.; Wu, C.; Walia, A.; Uchio, E.; Smith-Liu, F.; Zi, X. Rhodiola rosea L.: An Herb with Anti-Stress, Anti-Aging, and Immunostimulating Properties for Cancer Chemoprevention. Curr. Pharmacol. Rep. 2017, 3, 384-395. [CrossRef] [PubMed]

120. Talukdar, D.; Rhodiola Rosea, L. A critical review on biology, medicinal properties and pharmacological manifestations. J. Nat. Prod. Resour. 2015, 1, 4-9.

121. Dieamant, G.C.; Velazquez Pereda, M.D.C.; Eberlin, S.; Nogueira, C.; Werka, R.M.; De Queiroz, M.L.S. Neuroimmunomodulatory compound for sensitive skin care: In vitro and clinical assessment. J. Cosmet. Dermatol. 2008, 7, 112-119. [CrossRef] [PubMed]

122. Mimura, T.; Nakamura, Y.; Nishino, J.; Sawayama, T.; Komiya, T.; Deguchi, T.; Kita, A.; Nakamura, H.; Matsumoto, J. A novel class of enkephalinase inhibitors containing a C-terminal sulfo group. J. Med. Chem. 1992, 35, 602-608. [CrossRef]

123. Ogawa, K.; Nakamura, S.; Sugimoto, S.; Tsukioka, J.; Hinomaru, F.; Nakashima, S.; Matsumoto, T.; Ohta, T.; Fujimoto, K.; Yoshikawa, M.; et al. Constituents of flowers of Paeoniaceae plants, Paeonia suffruticosa and Paeonia lactiflora. Phytochem. Lett. 2015, 12, 98-104. [CrossRef] 
124. Torres-León, C.; Ventura-Sobrevilla, J.; Serna-Cock, L.; Ascacio-Valdés, J.A.; Contreras-Esquivel, J.; Aguilar, C.N. Pentagalloylglucose (PGG): A valuable phenolic compound with functional properties. J. Funct. Foods 2017, 37, 176-189. [CrossRef]

125. Kim, K.-H.; Shim, J.S.; Kim, H.-J.; Son, E.D. Penta-O-galloyl- $\beta$-D-glucose from Paeonia lactiflora Pall. root extract enhances the expression of skin barrier genes via EGR3. J. Ethnopharmacol. 2020, 248, 112337. [CrossRef]

126. Letsiou, S.; Bakea, A.; Holefors, A.; Rembiesa, J. In vitro protective effects of Paeonia mascula subsp. hellenica callus extract on human keratinocytes. Sci. Rep. 2020, 10, 19213. [CrossRef] [PubMed]

127. Li, P.; Shen, J.; Wang, Z.; Liu, S.; Liu, Q.; Li, Y.; He, C.; Xiao, P. Genus Paeonia: A comprehensive review on traditional uses, phytochemistry, pharmacological activities, clinical application, and toxicology. J. Ethnopharmacol. 2021, 269, 113708. [CrossRef] [PubMed]

128. NUXE Paris First Wrinkles Skincare Nirvanesque ${ }^{\circledR}$. Available online: https://uk.nuxe.com/nirvanesque (accessed on 1 May 2021).

129. Lancome Hydra Zen Anti-Stress Cream Hydra Zen Anti-Stress Cream. Available online: https://www.lancome.co.uk/skincare/ by-product-category/moisturisers/hydra-zen-anti-stress-cream/085201-LAC.html (accessed on 12 May 2021).

130. Rao, A.S.; Yadav, S.S.; Singh, P.; Nandal, A.; Singh, N.; Ganaie, S.A.; Yadav, N.; Kumar, R.; Bhandoria, M.S.; Bansal, P. A comprehensive review on ethnomedicine, phytochemistry, pharmacology, and toxicity of Tephrosia purpurea (L.) Pers. Phyther. Res. 2020, 34, 1902-1925. [CrossRef]

131. Hubert, J.; Chollet, S.; Purson, S.; Reynaud, R.; Harakat, D.; Martinez, A.; Nuzillard, J.-M.; Renault, J.-H. Exploiting the Complementarity between Dereplication and Computer-Assisted Structure Elucidation for the Chemical Profiling of Natural Cosmetic Ingredients: Tephrosia purpurea as a Case Study. J. Nat. Prod. 2015, 78, 1609-1617. [CrossRef]

132. Altemus, M.; Rao, B.; Dhabhar, F.S.; Ding, W.; Granstein, R.D. Stress-induced changes in skin barrier function in healthy women. J. Investig. Dermatol. 2001, 117, 309-317. [CrossRef] [PubMed]

133. Bonte, F.; Dumas, M.; Lhermite, S.; Saunois, A. Use of Oligosaccharides to Stimulate Beta-endorphin Production. U.S. Patent Application No. 10/332,136, 21 August 2003.

134. Ahn, K.S.; Aggarwal, B.B. Transcription Factor NF-кB: A Sensor for Smoke and Stress Signals. Ann. N. Y. Acad. Sci. 2005, 1056, 218-233. [CrossRef] [PubMed]

135. Alexopoulos, A.; Chrousos, G.P. Stress-related skin disorders. Rev. Endocr. Metab. Disord. 2016, 17, 295-304. [CrossRef]

136. Cals-Grierson, M.-M.; Ormerod, A.D. Nitric oxide function in the skin. Nitric Oxide 2004, 10, 179-193. [CrossRef]

137. Costin, G.-E.; Hearing, V.J. Human skin pigmentation: Melanocytes modulate skin color in response to stress. FASEB J. 2007, 21, 976-994. [CrossRef]

138. Zielińska, S.; Matkowski, A. Phytochemistry and bioactivity of aromatic and medicinal plants from the genus Agastache (Lamiaceae). Phytochem. Rev. 2014, 13, 391-416. [CrossRef]

139. Provital Do Care Agascalm. Available online: https:/ / www.weareprovital.com/en/careactives/agascalm (accessed on 17 May 2021).

140. Brooke Schleehauf Provital Group's Agascalm. Available online: https://www.cosmeticsandtoiletries.com/formulating/ category/skincare/Provital-Groups-Agascalm-477545493.html (accessed on 10 May 2021).

141. Hakozaki, T.; Deyer, B.F.; Laughlin II, L.T. Skin Care Composition. 2019. Available online: https://patents.google.com/patent/ US20200405614A1/en (accessed on 7 May 2021).

142. Paufique, J. Active Ingredient Obtained From Nymphaea Alba Flowers. U.S. Patent Application No 16/912,958, 31 December 2020.

143. Ronsisvalle, S.; Panarello, F.; Longhitano, G.; Siciliano, E.A.; Montenegro, L.; Panico, A. Natural Flavones and Flavonols: Relationships among Antioxidant Activity, Glycation, and Metalloproteinase Inhibition. Cosmetics 2020, 7, 71. [CrossRef]

144. Chang, Y.-S.; Chiang, B.-L. Sleep disorders and atopic dermatitis: A 2-way street? J. Allergy Clin. Immunol. 2018, 142, 1033-1040. [CrossRef]

145. Oliveira, C.; Torres, T. More than skin deep: The systemic nature of atopic dermatitis. Eur. J. Dermatol. 2019, 29, 250-258. [CrossRef] [PubMed]

146. Slominski, A.; Fischer, T.W.; Zmijewski, M.A.; Wortsman, J.; Semak, I.; Zbytek, B.; Slominski, R.M.; Tobin, D.J. On the role of melatonin in skin physiology and pathology. Endocrine 2005, 27, 137-147. [CrossRef]

147. Slominski, A.T.; Zmijewski, M.A.; Semak, I.; Kim, T.-K.; Janjetovic, Z.; Slominski, R.M.; Zmijewski, J.W. Melatonin, mitochondria, and the skin. Cell. Mol. Life Sci. 2017, 74, 3913-3925. [CrossRef] [PubMed]

148. Wang, D.; Imae, T.; Miki, M. Fluorescence emission from PAMAM and PPI dendrimers. J. Colloid Interface Sci. 2007, 306, 222-227. [CrossRef]

149. Dong, K.; Goyarts, E.C.; Pelle, E.; Trivero, J.; Pernodet, N. Blue light disrupts the circadian rhythm and create damage in skin cells. Int. J. Cosmet. Sci. 2019, 41, 558-562. [CrossRef] [PubMed]

150. Slominski, A.; Tobin, D.J.; Zmijewski, M.A.; Wortsman, J.; Paus, R. Melatonin in the skin: Synthesis, metabolism and functions. Trends Endocrinol. Metab. 2008, 19, 17-24. [CrossRef]

151. Ndiaye, M.A.; Nihal, M.; Wood, G.S.; Ahmad, N. Skin, Reactive Oxygen Species, and Circadian Clocks. Antioxid. Redox Signal. 2013, 20, 2982-2996. [CrossRef] [PubMed] 
152. Granger, C.; Brown, A.; Aladren, S.; Narda, M. Night Cream Containing Melatonin, Carnosine and Helichrysum italicum Extract Helps Reduce Skin Reactivity and Signs of Photodamage: Ex Vivo and Clinical Studies. Dermatol. Ther. 2020, 10, 1315-1329. [CrossRef]

153. Lan, A.L.; Lu, N.; Kang, D.; Ye, L.; Lintner, K.; Zappelli, C.; Apone, F.; Colucci, M.G.; Bimonte, M.; Bertelli, G.; et al. NeuroCosmetics Approach: TCM based formula with HACCE stem cell extract reduces stress symptoms by activating cutaneous melatonin receptor MT1. In Proceedings of the 25th IFSCC Conference CosmEthic Science and Conscience, Milan, Italy, 30 September 2019.

154. Misery, L.; Ständer, S.; Szepietowski, J.; Reich, A.; Wallengren, J.; Evers, A.; Takamori, K.; Brenaut, E.; Le Gall-Ianotto, C.; Fluhr, J.; et al. Definition of Sensitive Skin: An Expert Position Paper from the Special Interest Group on Sensitive Skin of the International Forum for the Study of Itch. Acta Derm. Venereol. 2017, 97, 4-6. [CrossRef] [PubMed]

155. Wandrey, F.; Schmid, D.; Zülli, F. Peptide Inspired by Sea Anemone Venom Comforts Sensitive Skin. SOFW J. 2018, 19-23. Available online: https:/ /www.sofw.com/de/hikashop-menu-for-categories-listing/product/221-peptide-inspired-by-seaanemone-venom-comforts-sensitive-skin (accessed on 14 July 2021).

156. Misery, L.; Loser, K.; Ständer, S. Sensitive skin. J. Eur. Acad. Dermatol. Venereol. 2016, 30, 2-8. [CrossRef] [PubMed]

157. Yu, J.; Wang, G.; Jiang, N. Study on the Repairing Effect of Cosmetics Containing Artemisia annua on Sensitive Skin. J. Cosmet. Dermatol. Sci. Appl. 2020, 10, 8-19.

158. Prospector Mariliance ${ }^{\mathrm{TM}}$. Available online: https://www.ulprospector.com/en/asia/PersonalCare/Detail/831/724171 /Mariliance (accessed on 17 May 2021).

159. Do, L.H.D.; Azizi, N.; Maibach, H. Sensitive Skin Syndrome: An Update. Am. J. Clin. Dermatol. 2020, 21, 401-409. [CrossRef] [PubMed]

160. Misery, L.; Morisset, S.; Seite, S.; Brenaut, E.; Ficheux, A.-S.; Fluhr, J.W.; Delvigne, V.; Taieb, C. Relationship between sensitive skin and sleep disorders, fatigue, dust, sweating, food, tobacco consumption or female hormonal changes : Results from a worldwide survey of 10,743 individuals. J. Eur. Acad. Dermatol. Venereol. 2021, 35, 1371-1376. [CrossRef]

161. Kligman, A.M.; Sadiq, I.; Zhen, Y.; Crosby, M. Experimental studies on the nature of sensitive skin. Ski. Res. Technol. 2006, 12, 217-222. [CrossRef]

162. Givaudan Mariliance ${ }^{\mathrm{TM}}$ Marine Neuro-Soother. Available online: https://www.givaudan.com/fragrance-beauty/active-beauty/ products/mariliance (accessed on 17 May 2021).

163. Talagas, M.; Lebonvallet, N.; Berthod, F.; Misery, L. Cutaneous nociception: Role of keratinocytes. Exp. Dermatol. 2019, 28, 1466-1469. [CrossRef]

164. Misery, L. Sensitive Skins May Be Neuropathic Disorders: Lessons from Studies on Skin and Other Organs. Cosmetics 2021, 8, 14. [CrossRef]

165. Pinolumin for Flawless Skin. Available online: https:/ /www.personalcaremagazine.com/story/18396/pinolumin-for-flawlessskin (accessed on 17 May 2021).

166. Wandrey, F.; Schmid, D.; Zülli, F. Flawless skin via Swiss stone pine extract. Pers. CareA Asia Pac. 2016, 27-30. Available online: https://www.google.it/url?sa=t\&rct=j\&q=\&esrc=s\&source=web\&cd=\&ved=2ahUKEwiJ39Xa3-LxAhVO4 qQKHWZZApoQFnoECAUQAA\&url=https\%3A\%2F\%2Fesent.pl\%2Fpl\%2Fp\%2Ffile\%2F1d68c6828d2d78974480bee2712e0 596\%2FFlawless_Skin_Via_Swiss_Stone_Pine_Extract_Personal_Care_Magazine_November_2016-1.pdf\&usg=AOvVaw1 QJLnqDi0iNyb206vtRpQn (accessed on 14 July 2021).

167. Talagas, M.; Misery, L. Role of Keratinocytes in Sensitive Skin. Front. Med. 2019, 6, 108. [CrossRef]

168. Ehnis-Pérez, A.; Torres-Álvarez, B.; Cortés-García, D.; Hernández-Blanco, D.; Fuentes-Ahumada, C.; Castanedo-Cázares, J.P. Relationship between transient receptor potential vanilloid-1 expression and the intensity of sensitive skin symptoms. J. Cosmet. Dermatol. 2016, 15, 231-237. [CrossRef]

169. Caterina, M.J. Transient receptor potential ion channels as participants in thermosensation and thermoregulation. Am. J. Physiol. Integr. Comp. Physiol. 2007, 292, R64-R76. [CrossRef]

170. Lee, Y.M.; Kang, S.M.; Chung, J.H. The role of TRPV1 channel in aged human skin. J. Dermatol. Sci. 2012, 65, 81-85. [CrossRef]

171. Misery, L. Sensitive skin. Expert Rev. Dermatol. 2013, 8, 631-637. [CrossRef]

172. Mandadi, S.; Roufogalis, B.D. ThermoTRP channels in nociceptors: Taking a lead from capsaicin receptor TRPV1. Curr. Neuropharmacol. 2008, 6, 21-38. [CrossRef]

173. Cortright, D.N.; Szallasi, A. Biochemical pharmacology of the vanilloid receptor TRPV1. Eur. J. Biochem. 2004, 271, 1814-1819. [CrossRef] [PubMed]

174. Kueper, T.; Krohn, M.; Haustedt, L.O.; Hatt, H.; Schmaus, G.; Vielhaber, G. Inhibition of TRPV1 for the treatment of sensitive skin. Exp. Dermatol. 2010, 19, 980-986. [CrossRef]

175. Lee, Y.M.; Kim, Y.K.; Chung, J.H. Increased expression of TRPV1 channel in intrinsically aged and photoaged human skin in vivo. Exp. Dermatol. 2009, 18, 431-436. [CrossRef] [PubMed]

176. Costa, A.; Eberlin, S.; Polettini, A.J.; Da Costa Pereira, A.F.; Pereira, C.S.; Cortes Ferreira, N.M.; Dolis, E.; Oliveira Torloni, L.B. Neuromodulatory and Anti-Inflammatory Ingredient for Sensitive Skin: In Vitro Assessment. Inflamm. Allergy Drug Targets Former. Curr. Drug Targets Inflamm. Allergy 2014, 13, 191-198. [CrossRef] [PubMed]

177. Garg, C.; Sharma, H.; Garg, M. Skin photo-protection with phytochemicals against photo-oxidative stress, photo-carcinogenesis, signal transduction pathways and extracellular matrix remodeling-An overview. Ageing Res. Rev. 2020, 62, 101127. [CrossRef] 
178. Dupont, E.; Gomez, J.; Bilodeau, D. Beyond UV radiation: A skin under challenge. Int. J. Cosmet. Sci. 2013, 35, 224-232. [CrossRef]

179. Juráňová, J.; Franková, J.; Ulrichová, J. The role of keratinocytes in inflammation. J. Appl. Biomed. 2017, 15, 169-179. [CrossRef]

180. Pillai, S.; Oresajo, C.; Hayward, J. Ultraviolet radiation and skin aging: Roles of reactive oxygen species, inflammation and protease activation, and strategies for prevention of inflammation-induced matrix degradation-A review. Int. J. Cosmet. Sci. 2005, 27, 17-34. [CrossRef]

181. Dinarello, C.A. Interleukin 1 and interleukin 18 as mediators of inflammation and the aging process. Am. J. Clin. Nutr. 2006, 83, 447S-455S. [CrossRef]

182. Christopoulos, G.I.; Uy, M.A.; Yap, W.J. The Body and the Brain: Measuring Skin Conductance Responses to Understand the Emotional Experience. Org. Res. Methods 2019, 22, 394-420. [CrossRef]

183. Matsumura, S.; Terao, M.; Murota, H.; Katayama, I. Th2 cytokines enhance TrkA expression, upregulate proliferation, and downregulate differentiation of keratinocytes. J. Dermatol. Sci. 2015, 78, 215-223. [CrossRef]

184. Feliciani, C.; Gupta, A.K.; Saucier, D.N. Keratinocytes and Cytokine/Growth Factors. Crit. Rev. Oral Biol. Med. 1996, 7, 300-318. [CrossRef]

185. Scandolera, A.; Hubert, J.; Humeau, A.; Lambert, C.; De Bizemont, A.; Winkel, C.; Kaouas, A.; Renault, J.-H.; Nuzillard, J.-M.; Reynaud, R. GABA and GABA-Alanine from the Red Microalgae Rhodosorus marinus Exhibit a Significant Neuro-Soothing Activity through Inhibition of Neuro-Inflammation Mediators and Positive Regulation of TRPV1-Related Skin Sensitization. Mar. Drugs 2018, 16, 96. [CrossRef] [PubMed]

186. Yun, J.-W.; Seo, J.A.; Jeong, Y.S.; Bae, I.-H.; Jang, W.-H.; Lee, J.; Kim, S.-Y.; Shin, S.-S.; Woo, B.-Y.; Lee, K.-W.; et al. TRPV1 antagonist can suppress the atopic dermatitis-like symptoms by accelerating skin barrier recovery. J. Dermatol. Sci. 2011, 62, 8-15. [CrossRef] [PubMed]

187. Yang, G.; Seok, J.K.; Kang, H.C.; Cho, Y.-Y.; Lee, H.S.; Lee, J.Y. Skin Barrier Abnormalities and Immune Dysfunction in Atopic Dermatitis. Int. J. Mol. Sci. 2020, 21, 2867. [CrossRef] [PubMed]

188. Voisin, T.; Chiu, I.M. Molecular link between itch and atopic dermatitis. Proc. Natl. Acad. Sci. USA 2018, 115, 12851-12853. [CrossRef] [PubMed]

189. Williams, H.C. Atopic Dermatitis. N. Engl. J. Med. 2005, 352, 2314-2324. [CrossRef]

190. Bonchak, J.G.; Swerlick, R.A. Emerging therapies for atopic dermatitis: TRPV1 antagonists. J. Am. Acad. Dermatol. 2018, 78, S63-S66. [CrossRef]

191. Liu, T.; Ji, R.-R. Oxidative stress induces itch via activation of transient receptor potential subtype ankyrin 1 in mice. Neurosci. Bull. 2012, 28, 145-154. [CrossRef]

192. Neuro-Soother for Comfort. Available online: https://www.personalcaremagazine.com/story/14348/formulations (accessed on 12 May 2021).

193. Ngo, D.-H.; Vo, T.S. An Updated Review on Pharmaceutical Properties of Gamma-Aminobutyric Acid. Molecules 2019, $24,2678$. [CrossRef]

194. Mibelle Group Biochemistry Pinolumin ${ }^{\mathrm{TM}}$ Relax Your Skin-Enjoy a Flawless Complexion. Available online: https: // mibellebiochemistry.com/pinolumintm (accessed on 15 May 2021).

195. Human Research Stone Pine. Available online: http:// humanresearch.at/newwebcontent/?page_id=96\&lang=en (accessed on 16 May 2021).

196. Ghadiriasli, R.; Mahmoud, M.A.A.; Wagenstaller, M.; Van de Kuilen, J.W.; Buettner, A. Molecular and sensory characterization of odorants in Cembran pine (Pinus cembra L.) from different geographic regions. Talanta 2020, 220, 121380. [CrossRef]

197. Kotradyova, V.; Vavrinsky, E.; Kalinakova, B.; Petro, D.; Jansakova, K.; Boles, M.; Svobodova, H. Wood and Its Impact on Humans and Environment Quality in Health Care Facilities. Int. J. Environ. Res. Public Health 2019, 16, 3496. [CrossRef]

198. Eräsalo, H.; Hämäläinen, M.; Leppänen, T.; Mäki-Opas, I.; Laavola, M.; Haavikko, R.; Yli-Kauhaluoma, J.; Moilanen, E. Natural Stilbenoids Have Anti-Inflammatory Properties in Vivo and Down-Regulate the Production of Inflammatory Mediators NO, IL6, and MCP1 Possibly in a PI3K/Akt-Dependent Manner. J. Nat. Prod. 2018, 81, 1131-1142. [CrossRef] [PubMed]

199. Laavola, M.; Nieminen, R.; Leppänen, T.; Eckerman, C.; Holmbom, B.; Moilanen, E. Pinosylvin and Monomethylpinosylvin, Constituents of an Extract from the Knot of Pinus sylvestris, Reduce Inflammatory Gene Expression and Inflammatory Responses in Vivo. J. Agric. Food Chem. 2015, 63, 3445-3453. [CrossRef] [PubMed]

200. Reinisalo, M.; Kårlund, A.; Koskela, A.; Kaarniranta, K.; Karjalainen, R.O. Polyphenol Stilbenes: Molecular Mechanisms of Defence against Oxidative Stress and Aging-Related Diseases. Oxid. Med. Cell. Longev. 2015, 2015, 340520. [CrossRef] [PubMed]

201. Brenneisen, P.; Sies, H.; Scharffetter-Kochanek, K. Ultraviolet-B Irradiation and Matrix Metalloproteinases. Ann. N. Y. Acad. Sci. 2002, 973, 31-43. [CrossRef] [PubMed]

202. Bauerova, K.; Acquaviva, A.; Ponist, S.; Gardi, C.; Vecchio, D.; Drafi, F.; Arezzini, B.; Bezakova, L.; Kuncirova, V.; Mihalova, D.; et al. Markers of inflammation and oxidative stress studied in adjuvant-induced arthritis in the rat on systemic and local level affected by pinosylvin and methotrexate and their combination. Autoimmunity 2015, 48, 46-56. [CrossRef]

203. Abbas, M.A. Modulation of TRPV1 channel function by natural products in the treatment of pain. Chem. Biol. Interact. 2020, 330, 109178. [CrossRef]

204. BASF Skinasensyl ${ }^{\circledR}$ LS 9749. Available online: https:/ / carecreations.basf.us/products/skinasensyl-1s-9749 (accessed on 17 May 2021). 
205. Schaefer, K. Tetrapeptide for Neurosensitive Skin. Available online: https://www.cosmeticsandtoiletries.com/formulating/ function/antiirritant/35799934.html (accessed on 8 May 2021).

206. BASF LS Skinasensyl-A Next-Generation Cosmeceutical for Sensitive Skin. Available online: https:/ / www.pressebox.com/ inactive/basf/LS-Skinasensyl-a-next-generation-cosmeceutical-for-sensitive-skin/boxid/215473 (accessed on 17 May 2021).

207. Olejnik, A.; Kapuscinska, A.; Schroeder, G.; Nowak, I. Physico-chemical characterization of formulations containing endomorphin2 derivatives. Amino Acids 2017, 49, 1719-1731. [CrossRef] [PubMed]

208. BASF Skinasensyl. The Neurocosmeceutical Soother. Available online: https: / www.google.it/url? sa=t\&rct=j\&q=\&esrc= s\&source=web\&cd=\&ved=2ahUKEwixm9jK9NLwAhWGGewKHYZ0CfsQFjAAegQIBRAD\&url=https\%253A\%252F\%25 2Fbiakhim.com.ua\%252Findex.php\%253Foption\%253Dcom_k2\%2526Itemid\%253D1173\%2526id\%253D617_5786cf0e9694d655 383c8947159ba238\%2526lang\%253Dru\%2526task\%253 (accessed on 18 May 2021).

209. Lintner, K. Chapter 36: Peptides and Proteins. In Cosmetic Dermatology: Products and Procedures; Draelos, Z.D., Ed.; John Wiley \& Sons, Ltd.: Oxford, UK, 2016; pp. 308-317, ISBN 978-1-118-65558-0.

210. Wandrey, F.; Schmid, D.; Zülli, F. Personal Care Europe. 2017, pp. 117-119.

211. Andreev, Y.A.; Kozlov, S.A.; Koshelev, S.G.; Ivanova, E.A.; Monastyrnaya, M.M.; Kozlovskaya, E.P.; Grishin, E. V Analgesic compound from sea anemone Heteractis crispa is the first polypeptide inhibitor of vanilloid receptor 1 (TRPV1). J. Biol. Chem. 2008, 283, 23914-23921. [CrossRef] [PubMed]

212. Jardín, I.; López, J.J.; Diez, R.; Sánchez-Collado, J.; Cantonero, C.; Albarrán, L.; Woodard, G.E.; Redondo, P.C.; Salido, G.M.; Smani, T.; et al. TRPs in Pain Sensation. Front. Physiol. 2017, 8, 392. [CrossRef] [PubMed]

213. Vetter, I.; Lewis, R.J. Natural Product Ligands of TRP Channels BT_Transient Receptor Potential Channels; Islam, M.S., Ed.; Springer: Dordrecht, The Netherlands, 2011; pp. 41-85, ISBN 978-94-007-0265-3.

214. Kozlov, S.A.; Andreev, Y.A.; Murashev, A.N.; Skobtsov, D.I.; D’yachenko, I.A.; Grishin, E.V. New polypeptide components from the Heteractis crispa sea anemone with analgesic activity. Russ. J. Bioorganic Chem. 2009, 35, 711. [CrossRef]

215. Pauly, G.; Moussou, P.; Contet-Audonneau, J.-L.; Danoux, L.; Freis, O.; Sabadotto, M.; Benoit, I.; Misery, L.; Rathjens, A. New peptidic active ingredient to reduce discomfort and painful sensations in sensitive skin. Int. J. Cosmet. Sci. 2009, 31, 480. [CrossRef]

216. Nikolaev, M.V.; Dorofeeva, N.A.; Komarova, M.S.; Korolkova, Y.V.; Andreev, Y.A.; Mosharova, I.V.; Grishin, E.V.; Tikhonov, D.B.; Kozlov, S.A. TRPV1 activation power can switch an action mode for its polypeptide ligands. PLoS ONE 2017, 12, e0177077. [CrossRef] [PubMed]

217. Mibelle Group Biochemistry SensAmone P5: Immediate Comfort for Sensitive Skin. Available online: https:/ / mibellebiochemistry. com/sensamone-p5 (accessed on 17 May 2021).

218. SensAmone P5: Immediate Comfort for Sensitive Skin. Available online: https://www.cosmeticsbusiness.com/news/article_ page/SensAmone_P5_immediate_comfort_for_sensitive_skin/128848 (accessed on 17 May 2021).

219. Kimura, A.; Kanazawa, N.; Li, H.-J.; Yonei, N.; Yamamoto, Y.; Furukawa, F. Influence of chemical peeling on the skin stress response system. Exp. Dermatol. 2012, 21, 8-10. [CrossRef] [PubMed]

220. Slominski, A.; Wortsman, J.; Luger, T.; Paus, R.; Solomon, S. Corticotropin Releasing Hormone and Proopiomelanocortin Involvement in the Cutaneous Response to Stress. Physiol. Rev. 2000, 80, 979-1020. [CrossRef]

221. Coates, S.J.; Lee, E.H.; Granstein, R.D. Cutaneous Neuroimmunology BT—Clinical and Basic Immunodermatology; Gaspari, A.A., Tyring, S.K., Kaplan, D.H., Eds.; Springer International Publishing: Cham, Switzerland, 2017; pp. 179-199, ISBN 978-3-319-29785-9.

222. Bonezzi, C.; Costantini, A.; Cruccu, G.; Fornasari, D.M.M.; Guardamagna, V.; Palmieri, V.; Polati, E.; Zini, P.; Dickenson, A.H. Capsaicin 8\% dermal patch in clinical practice: An expert opinion. Expert Opin. Pharmacother. 2020, 21, 1377-1387. [CrossRef] [PubMed]

223. Rhodes, M.E. Adrenocorticotropic Hormone. In Stress: Neuroendocrinology and Neurobiology; Elsevier Inc.: Amsterdam, The Netherlands, 2017; Volume 2, pp. 109-116, ISBN 9780128024232.

224. Lintner, K.; Peschard, O. Biologically active peptides: From a laboratory bench curiosity to a functional skin care product. Int. J. Cosmet. Sci. 2000, 22, 207-218. [CrossRef]

225. Perazzo, J.; Marb, C.; Santos, S.S. Pharmacological Potential of the Endogenous Dipeptide Kyotorphin and Selected Derivatives. Front. Pharmacol. 1979, 7, 530. [CrossRef]

226. CRODA Calmosensine ${ }^{\mathrm{TM}}$ SP Sensual Healing, Embrace Yourself in Wellbeing. Available online: https://www.crodapersonalcare. com/en-gb/products-and-applications/product-finder/product/2960/Calmosensine_1_SP\#tab-collapse-literature (accessed on 17 May 2021).

227. RAHN DEFENSIL ${ }^{\circledR}$-SOFT Help Your Skin Chill Out. Available online: https://www.rahn-group.com/en/cosmetics/product/ 29/ (accessed on 30 April 2021).

228. Hettwer, S.; Bänziger, S.; Suter, B.; Obermayer, B. Grifolin derivatives from Albatrellus ovinus as TRPV1 receptor blockers for cosmetic applications. Int. J. Cosmet. Sci. 2017, 39, 379-385. [CrossRef]

229. Meotti, F.C.; Lemos de Andrade, E.; Calixto, J.B. TRP Modulation by Natural Compounds BT-Mammalian Transient Receptor Potential (TRP) Cation Channels: Volume II; Nilius, B., Flockerzi, V., Eds.; Springer International Publishing: Cham, Switzerland, 2014; pp. 1177-1238, ISBN 978-3-319-05161-1.

230. RAHN Rahn's DEFENSIL -SOFT Offers Zen-Like Soothing and Anti-Ageing Effects. Available online: https://www. cosmeticsbusiness.com/news/article_page/Rahns_DEFENSIL_SOFT_offers_zen-like_soothing_and_anti-ageing_effects/1329 34 (accessed on 17 May 2021). 
231. LucasMeyer-Cosmetics Lipopeptide Derived from a Neuromediator. Available online: https://www.lucasmeyercosmetics.com/ en/node/668 (accessed on 30 April 2021).

232. LucasMeyer-Cosmetics Neutrazen ${ }^{\mathrm{TM}}$ The Soothing Neurocosmetic. Available online: https://www.lucasmeyercosmetics.com/ en/taxonomy/term/123 (accessed on 30 April 2021).

233. Thody, A.J. $\alpha-\mathrm{MSH}$ and the Regulation of Melanocyte Function. Ann. N. Y. Acad. Sci. 1999, 885, 217-229. [CrossRef] [PubMed]

234. Böhm, M.; Schulte, U.; Kalden, H.; Luger, T.A. Alpha-Melanocyte-Stimulating Hormone Modulates Activation of NF- $k B$ and AP-1 and Secretion of Interleukin-8 in Human Dermal Fibroblasts. Ann. N. Y. Acad. Sci. 1999, 885, 277-286. [CrossRef] [PubMed]

235. Slominski, A.; Paus, R.; Wortsman, J. On the potential role of proopiomelanocortin in skin physiology and pathology. Mol. Cell. Endocrinol. 1993, 93, C1-C6. [CrossRef]

236. Auriemma, M.; Brzoska, T.; Klenner, L.; Kupas, V.; Goerge, T.; Voskort, M.; Zhao, Z.; Sparwasser, T.; Luger, T.A.; Loser, K. $\alpha$-MSH-Stimulated Tolerogenic Dendritic Cells Induce Functional Regulatory T Cells and Ameliorate Ongoing Skin Inflammation. J. Investig. Dermatol. 2012, 132, 1814-1824. [CrossRef] [PubMed]

237. Brzoska, T.; Luger, T.A.; Maaser, C.; Abels, C.; Böhm, M. $\alpha$-Melanocyte-Stimulating Hormone and Related Tripeptides: Biochemistry, Antiinflammatory and Protective Effects in Vitro and in Vivo, and Future Perspectives for the Treatment of Immune-Mediated Inflammatory Diseases. Endocr. Rev. 2008, 29, 581-602. [CrossRef] [PubMed]

238. Luger, T.A.; Scholzen, T.E.; Brzoska, T.; Böhm, M. New Insights into the Functions of $\alpha$-MSH and Related Peptides in the Immune System. Ann. N. Y. Acad. Sci. 2003, 994, 133-140. [CrossRef]

239. Bocheva, G.; Slominski, R.M.; Slominski, A.T. Neuroendocrine Aspects of Skin Aging. Int. J. Mol. Sci. 2019, 20, 2798. [CrossRef]

240. Scholzen, T.E.; Brzoska, T.; Kalden, D.-H.; O’Reilly, F.; Armstrong, C.A.; Luger, T.A.; Ansel, J.C. Effect of Ultraviolet Light on the Release of Neuropeptides and Neuroendocrine Hormones in the Skin: Mediators of Photodermatitis and Cutaneous Inflammation. J. Investig. Dermatol. Symp. Proc. 1999, 4, 55-60. [CrossRef]

241. Gouin, O.; L’Herondelle, K.; Lebonvallet, N.; Le Gall-Ianotto, C.; Sakka, M.; Buhé, V.; Plée-Gautier, E.; Carré, J.-L.; Lefeuvre, L.; Misery, L.; et al. TRPV1 and TRPA1 in cutaneous neurogenic and chronic inflammation: Pro-inflammatory response induced by their activation and their sensitization. Protein Cell 2017, 8, 644-661. [CrossRef]

242. Loing, E. Reaching a Zen-like State in Skin: Biomimetic Peptide to Balance Sensitivity. Available online: https://www. cosmeticsandtoiletries.com/testing/sensory/Reaching-a-Zen-like-State-in-Skin-Biomimetic-Peptide-to-Balance-Sensitivity420538914.html (accessed on 17 May 2021).

243. Leffingwell, J.C. Cooling Ingredients and Their Mechanism of Action. In Handbook of Cosmetic Science and Technology; Barel, A.O., Paye, M., Maibach, H.I., Eds.; Informa Healthcare USA, Inc.: New York, NY, USA, 2009; pp. 661-676, ISBN 978-1-4200-6963-1.

244. Salvona Encapsulation Technology HydroSal ${ }^{\circledR}$ SalCool. Available online: https://www.salvona.com/product/hydrosal-salcool/ (accessed on 13 May 2021).

245. InfinityIngredients HydroSal ${ }^{\mathrm{TM}}$ SalCool. Available online: https://infinity-ingredients.co.uk/product/salvona-hydrosal-salcool (accessed on 14 May 2021).

246. Givaudan Evercool ${ }^{\circledR}$ Skin Advanced Cooling Technology. Available online: https://www.givaudan.com/fragrance-beauty/ active-beauty/products/evercool-skin (accessed on 17 May 2021).

247. Leffingwell, J.C. Cool without Menthol \& Cooler than Menthol and Cooling Compounds as Insect Repellents. Available online: http:/ / www.leffingwell.com/cooler_than_menthol.htm\#b (accessed on 18 May 2021).

248. Rovner, S.L. Better Than Mint. Chem. Eng. News Arch. 2007, 85, 95. [CrossRef]

249. Babor Doctor Babor-Neuro Sensitive Cellular Intensive Calming Cleanser. Available online: https:/ /au.babor.com/products / doctor-babor/neuro-sensitive-cellular/59433-intensive-calming-cream.html\#text (accessed on 17 May 2021).

250. Muggli, R. Systemic evening primrose oil improves the biophysical skin parameters of healthy adults. Int. J. Cosmet. Sci. 2005, 27, 243-249. [CrossRef] [PubMed]

251. Michalak, M.; Pierzak, M.; Kręcisz, B.; Suliga, E. Bioactive Compounds for Skin Health: A Review. Nutrients 2021, 13, 203. [CrossRef] [PubMed]

252. Koch, W.; Zagórska, J.; Marzec, Z.; Kukula-Koch, W. Applications of Tea (Camellia sinensis) and Its Active Constituents in Cosmetics. Molecules 2019, 24, 4277. [CrossRef]

253. Yasin, Z.A.M.; Ibrahim, F.; Rashid, N.N.; Razif, M.F.M.; Yusof, R. The Importance of Some Plant Extracts as Skin Anti-aging Resources: A Review. Curr. Pharm. Biotechnol. 2017, 18, 864-876. [CrossRef] [PubMed]

254. Prasanth, M.; Sivamaruthi, B.; Chaiyasut, C.; Tencomnao, T. A Review of the Role of Green Tea (Camellia sinensis) in Antiphotoaging, Stress Resistance, Neuroprotection, and Autophagy. Nutrients 2019, 11, 474. [CrossRef]

255. Faccio, G. Plant Complexity and Cosmetic Innovation. iScience 2020, 23, 101358. [CrossRef]

256. LIPOTEC-Active Ingredients BODYFENSINE ${ }^{\circledR}$ Peptide. Available online: https://www.lipotec.com/en/products/bodyfensinereg-peptide/ (accessed on 17 May 2021).

257. Rull, M.; Davi, C.; Caufadas, E.; Cebriuen, J.; Delgado, R. Protect Skin, Reduce Discomfort. Available online: https://www.happi. com/issues/2013-10/view_features/protect-skin-reduce-discomfort (accessed on 15 May 2021).

258. Farage, M.A.; Miller, K.W.; Elsner, P.; Maibach, H.I. Characteristics of the Aging Skin. Adv. Wound Care 2012, 2, 5-10. [CrossRef] [PubMed]

259. Makrantonaki, E.; Zouboulis, C.C. Molecular Mechanisms of Skin Aging. Ann. N. Y. Acad. Sci. 2007, 1119, 40-50. [CrossRef] 
260. Fang, J.-Y.; Wang, P.-W.; Huang, C.-H.; Chen, M.-H.; Wu, Y.-R.; Pan, T.-L. Skin aging caused by intrinsic or extrinsic processes characterized with functional proteomics. Proteomics 2016, 16, 2718-2731. [CrossRef] [PubMed]

261. Tobin, D.J. Introduction to skin aging. J. Tissue Viability 2017, 26, 37-46. [CrossRef] [PubMed]

262. Farage, M.A.; Miller, K.W.; Elsner, P.; Maibach, H.I. Functional and physiological characteristics of the aging skin. Aging Clin. Exp. Res. 2008, 20, 195-200. [CrossRef]

263. Zhang, S.; Duan, E. Fighting against Skin Aging: The Way from Bench to Bedside. Cell Transplant. 2018, 27, 729-738. [CrossRef]

264. Gu, Y.; Han, J.; Jiang, C.; Zhang, Y. Biomarkers, oxidative stress and autophagy in skin aging. Ageing Res. Rev. 2020, 59, 101036. [CrossRef]

265. Bălașa, A.F.; Chircov, C.; Grumezescu, A.M. Marine Biocompounds for Neuroprotection—A Review. Mar. Drugs 2020, 18, 290. [CrossRef]

266. Boland, B.; Yu, W.H.; Corti, O.; Mollereau, B.; Henriques, A.; Bezard, E.; Pastores, G.M.; Rubinsztein, D.C.; Nixon, R.A.; Duchen, M.R.; et al. Promoting the clearance of neurotoxic proteins in neurodegenerative disorders of ageing. Nat. Rev. Drug Discov. 2018, 17, 660-688. [CrossRef] [PubMed]

267. Allan Butterfield, D. Amyloid $\beta$-peptide (1-42)-induced Oxidative Stress and Neurotoxicity: Implications for Neurodegeneration in Alzheimer's Disease Brain. A Review. Free Radic. Res. 2002, 36, 1307-1313. [CrossRef]

268. Ho, Y.-S.; So, K.-F.; Chang, R.C.-C. Anti-aging herbal medicine--How and why can they be used in aging-associated neurodegenerative diseases? Ageing Res. Rev. 2010, 9, 354-362. [CrossRef] [PubMed]

269. Kostomoiri, M.; Fragkouli, A.; Sagnou, M.; Skaltsounis, L.A.; Pelecanou, M.; Tsilibary, E.C.; Tzinia, A.K. Oleuropein, an Antioxidant Polyphenol Constituent of Olive Promotes $\alpha$-Secretase Cleavage of the Amyloid Precursor Protein (A $\beta$ PP). Cell. Mol. Neurobiol. 2013, 33, 147-154. [CrossRef] [PubMed]

270. Sankaranarayanan, S.; Price, E.A.; Wu, G.; Crouthamel, M.-C.; Shi, X.-P.; Tugusheva, K.; Tyler, K.X.; Kahana, J.; Ellis, J.; Jin, L.; et al. In Vivo $\beta$-Secretase 1 Inhibition Leads to Brain A $\beta$ Lowering and Increased $\alpha$-Secretase Processing of Amyloid Precursor Protein without Effect on Neuregulin-1. J. Pharmacol. Exp. Ther. 2008, 324, 957-969. [CrossRef]

271. Fukumoto, H.; Rosene, D.L.; Moss, M.B.; Raju, S.; Hyman, B.T.; Irizarry, M.C. $\beta$-Secretase Activity Increases with Aging in Human, Monkey, and Mouse Brain. Am. J. Pathol. 2004, 164, 719-725. [CrossRef]

272. Del Crdenas-Aguayo, M.C.; Del Silva-Lucero, M.C.; Cortes-Ortiz, M.; Jimnez-Ramos, B.; Gmez-Virgilio, L.; Ramrez-Rodrguez, G.; Vera- Arroyo, E.; Fiorentino-Prez, R.; Garca, U.; Luna-Muoz, J.; et al. Physiological Role of Amyloid Beta in Neural Cells: The Cellular Trophic Activity. In Neurochemistry; IntechOpen: London, UK, 2014.

273. Codif Technologie Naturelle; Codif STOECHIOL. Available online: https://cosmetics.specialchem.com/product/i-codifstoechiol (accessed on 17 May 2021).

274. Yankner, B.A.; Duffy, L.K.; Kirschner, D.A. Neurotrophic and neurotoxic effects of amyloid beta protein: Reversal by tachykinin neuropeptides. Science 1990, 250, 279-282. [CrossRef]

275. CODIF R\&N Neuroguard The New Science of Aging. Available online: https: $/ /$ www.google.com $/$ url? sa $=t \& r c t=j \& q=\& e s r c=$ s\&source=web\&cd=\&ved=2ahUKEwjfoYiB58bwAhVODOwKHZ1rC-UQFjAAegQIAxAD\&url=http\%3A\%2F\%2Fwww.codiftn.com\%2Fwp-content\%2Fuploads\%2F2016\%2F02\%2FNEUROGUARD-BROCHURE-GB.pdf\&usg=AOvVaw0gbO4Tbd7Lg6 SSJinuahoC (accessed on 17 May 2021).

276. Codif Technologie Naturelle Neuroguard. Available online: http://www.codif-tn.com/en/principesactifs/neuroguard/ (accessed on 17 May 2021).

277. Menéndez-González, M.; Pérez-Pinera, P.; Martínez-Rivera, M.; Calatayud, M.T.; Blázquez Menes, B. APP Processing and the APP-KPI Domain Involvement in the Amyloid Cascade. Neurodegener. Dis. 2005, 2, 277-283. [CrossRef]

278. Barbalace, M.C.; Malaguti, M.; Giusti, L.; Lucacchini, A.; Hrelia, S.; Angeloni, C. Anti-Inflammatory Activities of Marine Algae in Neurodegenerative Diseases. Int. J. Mol. Sci. 2019, 20, 3061. [CrossRef] [PubMed]

279. Codif Advanced Skin Care-Neurocosmetics-New Public 60+. Available online: https://www.google.it/url?sa=t\&rct=j\&q= \&esrc $=$ \&\&source=web\&cd=\&ved=2ahUKEwiHztyVrsbwAhVOhv0HHWqgBP8QFjABegQIBhAD\&url=http $\% 3 \mathrm{~A} \% 2 \mathrm{~F} \% 2 \mathrm{Fwww}$.

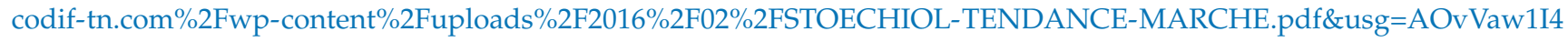
oHtceOwACmdIvUw9kZS (accessed on 17 May 2021).

280. Tajima, S.; Inoue, H.; Kawada, A.; Ishibashi, A.; Takahara, H.; Hiura, N. Alginate oligosaccharides modulate cell morphology, cell proliferation and collagen expression in human skin fibroblasts in vitro. Arch. Dermatol. Res. 1999, 291, 432-436. [CrossRef]

281. Park, R.-M.; Ahn, J.-Y.; Kim, S.Y.; Wee, J.-H.; Kim, Y.-H.; Min, J. Effect of Alginate Oligosaccharides on Collagen Expression in HS 27 Human Dermal Fibroblasts. Toxicol. Environ. Health Sci. 2019, 11, 327-334. [CrossRef]

282. Alaca, S.; Gedik, G. Evaluation of the effect of anti-pollution anti-aging eye cream on the collagen contraction. J. Pharm. Technol. 2020, 1, 13-17. [CrossRef]

283. Szekalska, M.; Puciłowska, A.; Szymańska, E.; Ciosek, P.; Winnicka, K. Alginate: Current Use and Future Perspectives in Pharmaceutical and Biomedical Applications. Int. J. Polym. Sci. 2016, 2016, 7697031. [CrossRef]

284. Xing, M.; Cao, Q.; Wang, Y.; Xiao, H.; Zhao, J.; Zhang, Q.; Ji, A.; Song, S. Advances in Research on the Bioactivity of Alginate Oligosaccharides. Mar. Drugs 2020, 18, 144. [CrossRef]

285. Eftekharzadeh, B.; Khodagholi, F.; Abdi, A.; Maghsoudi, N. Alginate protects NT2 neurons against H2O2-induced neurotoxicity. Carbohydr. Polym. 2010, 79, 1063-1072. [CrossRef] 
286. Priyan Shanura Fernando, I.; Kim, K.-N.; Kim, D.; Jeon, Y.-J. Algal polysaccharides: Potential bioactive substances for cosmeceutical applications. Crit. Rev. Biotechnol. 2019, 39, 99-113. [CrossRef]

287. Vieira, T.F.; Corrêa, R.C.G.; Peralta, R.A.; Peralta-Muniz-Moreira, R.F.; Bracht, A.; Peralta, R.M. An Overview of Structural Aspects and Health Beneficial Effects of Antioxidant Oligosaccharides. Curr. Pharm. Des. 2020, 26, 1759-1777. [CrossRef]

288. Biosil Technologies Glistin. Available online: http:/ / www.biosiltech.com/glistin/ (accessed on 17 May 2021).

289. Kang, C.K.; Lim, H.J.; Kim, J.H.Y.; Cho, S.A.; Kim, J.H.Y.; Park, N.H.; Kim, Y.J.; Cho, J.C.; Han, S.H. Anti-Aging Cosmetic Composition Containing Glutamylamidoethyl Indole. 2010. Available online: https://patents.google.com/patent/KR101520333 B1/en (accessed on 19 May 2021).

290. Exsymol Neurocosmetics. Available online: https:/ / www.exsymol.com/en/dossier/neuro-cosmetique/ (accessed on 17 May 2021).

291. Exsymol Biosil Technologies Glutrapeptide. Available online: http:/ / www.biosiltech.com/glutrapeptide/ (accessed on 17 May 2021).

292. Prouheze, P.; Morand, B.; Nicolaÿ, J.-F.; Fréchet, M. Preservation of Sympathetic Neuron-Adipocyte Crosstalk May Limit Chronic Emotional Stress-Mediated Fat Accu-mulation. IFSCC Mag. 2014, 17, 17-21.

293. Wang, A.S.; Dreesen, O. Biomarkers of Cellular Senescence and Skin Aging. Front. Genet. 2018, 9, 247. [CrossRef] [PubMed]

294. Gruber, F.; Kremslehner, C.; Eckhart, L.; Tschachler, E. Cell aging and cellular senescence in skin aging-Recent advances in fibroblast and keratinocyte biology. Exp. Gerontol. 2020, 130, 110780. [CrossRef] [PubMed]

295. Wlaschek, M.; Maity, P.; Makrantonaki, E.; Scharffetter-Kochanek, K. Connective Tissue and Fibroblast Senescence in Skin Aging. J. Investig. Dermatol. 2021. [CrossRef] [PubMed]

296. Gragnani, A.; Cornick, S.; Chominski, V.; Ribeiro de Noronha, S.; Alves Corrêa de Noronha, S.; Ferreira, L. Review of Major Theories of Skin Aging. Adv. Aging Res. 2014, 3, 49375. [CrossRef]

297. Skoczyńska, A.; Budzisz, E.; Dana, A.; Rotsztejn, H. New look at the role of progerin in skin aging. Prz. Menopauzalny Menopause Rev. 2015, 14, 53-58. [CrossRef]

298. Cao, K.; Blair, C.D.; Faddah, D.A.; Kieckhaefer, J.E.; Olive, M.; Erdos, M.R.; Nabel, E.G.; Collins, F.S. Progerin and telomere dysfunction collaborate to trigger cellular senescence in normal human fibroblasts. J. Clin. Investig. 2011, 121, $2833-2844$. [CrossRef]

299. Takeuchi, H.; Rünger, T.M. Longwave UV Light Induces the Aging-Associated Progerin. J. Investig. Dermatol. 2013, 133, 1857-1862. [CrossRef]

300. LucasMeyer-Cosmetics Biomimetic Peptide Derived from Elafin. Available online: https://www.lucasmeyercosmetics.com/en/ node/677 (accessed on 17 May 2021).

301. Schagen, S. Topical Peptide Treatments with Effective Anti-Aging Results. Cosmetics 2017, 4, 16. [CrossRef]

302. Loing, E.; Suere, T.; Lamarque, E. Trifluoroacetyl-Tripeptide-2 to Target Senescence for Anti-aging Benefits. Available online: https:/ / www.cosmeticsandtoiletries.com/formulating/category/skincare/premium-Trifluoroacetyl-Tripeptide-2-to-TargetSenescence-for-Anti-aging-Benefits-227412651.html (accessed on 17 May 2021).

303. Ferreira, M.S.; Magalhães, M.C.; Sousa-Lobo, J.M.; Almeida, I.F. Trending Anti-Aging Peptides. Cosmetics 2020, 7, 91. [CrossRef]

304. Pain, S.; Nakajima, S.; Altobelli, C.; Boher, A.; Cittadini, L.; Favre-Mercuret, M.; Sohm, B.; Vogelgesang, B.; Andre-Frei, V. Achillea millefolium extract: An innovative anti-aging neuro-cosmetic ingredient. J. Dermatol. Sci. 2013, 69, e52. [CrossRef]

305. Pain, S.; Altobelli, C.; Boher, A.; Cittadini, L.; Favre-Mercuret, M.; Gaillard, C.; Sohm, B.; Vogelgesang, B.; André-Frei, V. Surface rejuvenating effect of Achillea millefolium extract. Int. J. Cosmet. Sci. 2011, 33, 535-542. [CrossRef] [PubMed]

306. BASF NEUROBIOX ${ }^{\circledR}$ BC10097 The Ultimate Biological Skin Imperfections Blurring Solution. Available online: https: //www.carecreations.basf.com/product-formulations/product-highlights/product-highlights-detail/NEUROBIOXBC10097 /30715899 (accessed on 17 May 2021).

307. BASF Care Creations Neurobiox ${ }^{\mathrm{TM}}$ The Skin Biosurfacer. Available online: https:/ / docplayer.net/63928594-Neurobiox-tm-bybeauty-creations-the-skin-biosurfacer.html (accessed on 17 May 2021).

308. Lana, J.; Ascenso, A. New Trends in Anti-Aging Skin Care. In Carrier-Mediated Dermal Delivery: Applications in the Prevention and Treatment of Skin Disorders; Ascenso, A., Simões, S., Ribeiro, H., Eds.; Pan Stanford Publishing Pte. Ltd.: Singapore, 2017; pp. 3-41, ISBN 978-1-315-36447-6.

309. Codif Technologie Naturelle Neurolight. Available online: http:/ / www.codif-tn.com/en/principesactifs/neurolight/ (accessed on 17 May 2021).

310. Legat, F.J.; Wolf, P. Photodamage to the cutaneous sensory nerves: Role in photoaging and carcinogenesis of the skin? Photochem. Photobiol. Sci. 2006, 5, 170-176. [CrossRef] [PubMed]

311. Pietsch, E.C.; Sykes, S.M.; McMahon, S.B.; Murphy, M.E. The p53 family and programmed cell death. Oncogene 2008, $27,6507-6521$. [CrossRef]

312. Gritsenko, D.A.; Orlova, O.A.; Linkova, N.S.; Khavinson, V.K. Transcription factor p53 and skin aging. Adv. Gerontol. 2017, 7, 114-119. [CrossRef]

313. Brady, C.A.; Attardi, L.D. p53 at a glance. J. Cell Sci. 2010, 123, 2527-2532. [CrossRef]

314. Rachmin, I.; Ostrowski, S.M.; Weng, Q.Y.; Fisher, D.E. Topical treatment strategies to manipulate human skin pigmentation. Adv. Drug Deliv. Rev. 2020, 153, 65-71. [CrossRef] 
315. Murase, D.; Hachiya, A.; Amano, Y.; Ohuchi, A.; Kitahara, T.; Takema, Y. The Essential Role of p53 in Hyperpigmentation of the Skin via Regulation of Paracrine Melanogenic Cytokine Receptor Signaling. J. Biol. Chem. 2009, 284, 4343-4353. [CrossRef] [PubMed]

316. Elewa, R.; Makrantonaki, E.; Zouboulis, C.C. Neuropeptides and skin aging. Horm. Mol. Biol. Clin. Investig. 2013, 16, 29-33. [CrossRef] [PubMed]

317. Tuteja, G.; Kaestner, K.H. SnapShot: Forkhead Transcription Factors I. Cell 2007, 130, 1160.e1-1160.e2. [CrossRef]

318. Calissi, G.; Lam, E.W.-F.; Link, W. Therapeutic strategies targeting FOXO transcription factors. Nat. Rev. Drug Discov. 2021, 20, 21-38. [CrossRef] [PubMed]

319. Calnan, D.R.; Brunet, A. The FoxO code. Oncogene 2008, 27, 2276-2288. [CrossRef]

320. Yamamoto, M.; Clark, J.D.; Pastor, J.V.; Gurnani, P.; Nandi, A.; Kurosu, H.; Miyoshi, M.; Ogawa, Y.; Castrillon, D.H.; Rosenblatt, K.P.; et al. Regulation of Oxidative Stress by the Anti-aging Hormone Klotho. J. Biol. Chem. 2005, 280, 38029-38034. [CrossRef] [PubMed]

321. Kuro-o, M. Klotho and aging. Biochim. Biophys. Acta Gen. Subj. 2009, 1790, 1049-1058. [CrossRef]

322. Xu, Y.; Sun, Z. Molecular Basis of Klotho: From Gene to Function in Aging. Endocr. Rev. 2015, 36, 174-193. [CrossRef]

323. Wang, Y.; Sun, Z. Current understanding of klotho. Ageing Res. Rev. 2009, 8, 43-51. [CrossRef] [PubMed]

324. Banerjee, I.; Jaiswal, K.K. The role of the Klotho protein in the function of aging and neurodegenerative disorders. Octa J. Biosci. 2019, 7, 113-118.

325. Sotiropoulou, G.; Zingkou, E.; Pampalakis, G. Redirecting drug repositioning to discover innovative cosmeceuticals. Exp. Dermatol. 2021, 30, 628-644. [CrossRef]

326. Moeini, R.; Memariani, Z.; Asadi, F.; Bozorgi, M.; Gorji, N. Pistacia Genus as a Potential Source of Neuroprotective Natural Products. Planta Med 2019, 85, 1326-1350. [CrossRef] [PubMed]

327. Codif Technologie Naturelle LAKESIS. Available online: http:/ / www.codif-tn.com/en/principesactifs/lakesis/ (accessed on 17 May 2021).

328. Zeldich, E.; Chen, C.-D.; Colvin, T.A.; Bove-Fenderson, E.A.; Liang, J.; Tucker Zhou, T.B.; Harris, D.A.; Abraham, C.R. The Neuroprotective Effect of Klotho is Mediated via Regulation of Members of the Redox System. J. Biol. Chem. 2014, 289, 24700-24715. [CrossRef]

329. Yodoi, J.; Matsuo, Y.; Tian, H.; Masutani, H.; Inamoto, T. Anti-Inflammatory Thioredoxin Family Proteins for Medicare, Healthcare and Aging Care. Nutrients 2017, 9, 1081. [CrossRef]

330. Bachem Cosmetic Peptides. Available online: https://www.bachem.com/knowledge-center/white-papers/ (accessed on 10 May 2021).

331. Rodan, K.; Fields, K.; Falla, T. Bioactive Peptide. In Cosmeceuticals and Cosmetic Practice; Farris, P.K., Ed.; John Wiley \& Sons, Ltd: Oxford, UK, 2014; pp. 142-152, ISBN 978-1-118-38483-1.

332. Fields, K.; Falla, T.J.; Rodan, K.; Bush, L. Bioactive peptides: Signaling the future. J. Cosmet. Dermatol. 2009, 8, 8-13. [CrossRef]

333. Aguilar-Toalá, J.E.; Hernández-Mendoza, A.; González-Córdova, A.F.; Vallejo-Cordoba, B.; Liceaga, A.M. Potential role of natural bioactive peptides for development of cosmeceutical skin products. Peptides 2019, 122, 170170. [CrossRef]

334. Carli, B. Stop the Clock: Botox Alternatives. HPC Today Househ. Pers. Care Today 2017, 12, 52-54.

335. Gorouhi, F.; Maibach, H.I. Role of topical peptides in preventing or treating aged skin. Int. J. Cosmet. Sci. 2009, 31, 327-345. [CrossRef]

336. Khalid, F.; Gorouhi, F.; Maibach, H.I. Anti-Aging Topical Peptides and Proteins. In Cosmeceuticals and Active Cosmetics; Sivamani, R.K., Jagdeo, J.R., Elsner, P., Maibach, H.I., Eds.; CRC Press Taylor \& Francis Group: Boca Raton, FL, USA, 2016; pp. 127-161, ISBN 978-1-4822-1417-8.

337. Łubkowska, B.; Grobelna, B.; Maćkiewicz, Z. The use of synthetic polypeptides in cosmetics. Copernic. Lett. 2010, 1, 75-82. [CrossRef]

338. Apone, F.; Barbulova, A.; Colucci, M.G. Plant and Microalgae Derived Peptides Are Advantageously Employed as Bioactive Compounds in Cosmetics. Front. Plant Sci. 2019, 10, 756. [CrossRef]

339. Hajfathalian, M.; Ghelichi, S.; García-Moreno, P.J.; Moltke Sørensen, A.-D.; Jacobsen, C. Peptides: Production, bioactivity, functionality, and applications. Crit. Rev. Food Sci. Nutr. 2018, 58, 3097-3129. [CrossRef]

340. Oshimura, E.; Sakamoto, K. Amino Acids, Peptides, and Proteins. In Cosmetic Science and Technology: Theoretical Principles and Applications; Sakamoto, K., Lochhead, R.Y., Maibach, H.I., Yamashita, Y., Eds.; Elsevier Inc.: Amsterdam, The Netherlands, 2017; pp. 285-304, ISBN 978-0-12-802005-0.

341. Goldstein, M.; Lintner, K. Cosmetics \& Toiletries ${ }^{\circledR}$ Magazine. 2007. Available online: https://www.cosmeticsandtoiletries.com/ (accessed on 10 June 2021).

342. Najafi, H.; Jafari, M.; Abolmaali, S. Recent Approaches in the Treatment of Skin Ageing by Synthetic Bioactive Peptides. Sadra Med. J. 2019, 7, 317-334. [CrossRef]

343. Agyei, D.; Ongkudon, C.M.; Wei, C.Y.; Chan, A.S.; Danquah, M.K. Bioprocess challenges to the isolation and purification of bioactive peptides. Food Bioprod. Process. 2016, 98, 244-256. [CrossRef]

344. Gomes, C.; Silva, A.C.; Marques, A.C.; Sousa Lobo, J.; Amaral, M.H. Biotechnology Applied to Cosmetics and Aesthetic Medicines. Cosmetics 2020, 7, 33. [CrossRef]

345. Zhang, L.; Falla, T.J. Cosmeceuticals and peptides. Clin. Dermatol. 2009, 27, 485-494. [CrossRef] 
346. Lupo, M.P.; Cole, A.L. Cosmeceutical Peptides. Dermatol. Ther. 2007, 20, 343-349. [CrossRef] [PubMed]

347. Aldag, C.; Nogueira Teixeira, D.; Leventhal, P.S. Skin rejuvenation using cosmetic products containing growth factors, cytokines, and matrikines: A review of the literature. Clin. Cosmet. Investig. Dermatol. 2016, 9, 411-419. [CrossRef]

348. Errante, F.; Ledwoń, P.; Latajka, R.; Rovero, P.; Papini, A.M. Cosmeceutical Peptides in the Framework of Sustainable Wellness Economy. Front. Chem. 2020, 8, 572923. [CrossRef]

349. Ledwoń, P.; Errante, F.; Papini, A.M.; Rovero, P.; Latajka, R. Peptides as Active Ingredients: A Challenge for Cosmeceutical Industry. Chem. Biodivers. 2021, 18, e2000833. [CrossRef] [PubMed]

350. Pillaiyar, T.; Manickam, M.; Namasivayam, V. Skin whitening agents: Medicinal chemistry perspective of tyrosinase inhibitors. J. Enzym. Inhib. Med. Chem. 2017, 32, 403-425. [CrossRef]

351. Lupo, M.P. Cosmeceutical Peptides. Dermatol. Surg. 2005, 31, 832-836. [CrossRef] [PubMed]

352. Tadini, K.A.; Mercurio, D.G.; Campos, P.M.B.G.M. Acetyl hexapeptide-3 in a cosmetic formulation acts on skin mechanical properties-Clinical study. Braz. J. Pharm. Sci. 2015, 51, 901-909. [CrossRef]

353. Kraeling, M.E.K.; Zhou, W.; Wang, P.; Ogunsola, O.A. In vitro skin penetration of acetyl hexapeptide-8 from a cosmetic formulation. Cutan. Ocul. Toxicol. 2015, 34, 46-52. [CrossRef] [PubMed]

354. Wisniewski, J.D.; Ellis, D.L.; Lupo, M.P. Facial Rejuvenation: Combining Cosmeceuticals With Cosmetic Procedures. Cutis 2014, 94, 122-126. [PubMed]

355. Benson, H.A.E.; Namjoshi, S. Proteins and peptides: Strategies for delivery to and across the skin. J. Pharm. Sci. 2008, 97, 3591-3610. [CrossRef]

356. Abu Samah, N.H.; Heard, C.M. Topically applied KTTKS: A review. Int. J. Cosmet. Sci. 2011, 33, 483-490. [CrossRef]

357. Nafisi, S.; Maibach, H.I. Nanotechnology in Cosmetics. In Cosmetic Science and Technology: Theoretical Principles and Applications; Sakamoto, K., Lochhead, R.Y., Maibach, H.I., Yamashita, Y., Eds.; Elsevier Inc.: Amsterdam, The Netherlands, 2017; pp. 337-369, ISBN 978-0-12-802005-0.

358. Long, L.; Zhang, J.; Yang, Z.; Guo, Y.; Hu, X.; Wang, Y. Transdermal delivery of peptide and protein drugs: Strategies, advantages and disadvantages. J. Drug Deliv. Sci. Technol. 2020, 60, 102007. [CrossRef]

359. Pillai, S.; Singh, S.; Oresajo, C. Percutaneous Delivery of Cosmetic Actives to the Skin. In Cosmetic Dermatology: Products and Procedures; Draelos, Z.D., Ed.; John Wiley \& Sons, Ltd: Oxford, UK, 2016; pp. 65-74, ISBN 978-1-118-65558-0.

360. Sugibayashi, K. Skin. In Skin Permeation and Disposition of Therapeutic and Cosmeceutical Compounds; Sugibayashi, K., Ed.; Springer Japan KK: Tokyo, Japan, 2017; pp. 3-11, ISBN 978-4-431-56526-0.

361. Förster, M.; Bolzinger, M.-A.; Fessi, H. Topical delivery of cosmetics and drugs. Molecular aspects of percutaneous absorption and delivery. Eur. J. Dermatol. 2009, 19, 309-323. [CrossRef]

362. Kim, B.; Cho, H.-E.; Moon, S.H.; Ahn, H.-J.; Bae, S.; Cho, H.-D.; An, S. Transdermal delivery systems in cosmetics. Biomed. Dermatol. 2020, 4, 10. [CrossRef]

363. Benson, H.A.E. Skin Structure, Function, and Permeation. In Transdermal and Topical Drug Delivery: Principles and Practice; Benson, H.A.E., Adam, C.W., Eds.; John Wiley and Sons Inc.: Hoboken, NJ, USA, 2012; pp. 3-22, ISBN 978-0-470-45029-1.

364. Patel, V.; Sharma, O.P.; Mehta, T. Nanocrystal: A novel approach to overcome skin barriers for improved topical drug delivery. Expert Opin. Drug Deliv. 2018, 15, 351-368. [CrossRef] [PubMed]

365. Ooi, K. Related Topic: Chemical Permeation Through Impaired Skin. In Skin Permeation and Disposition of Therapeutic and Cosmeceutical Compounds; Sugibayashi, K., Ed.; Springer Japan KK: Tokyo, Japan, 2017; pp. 87-91, ISBN 978-4-431-56526-0.

366. Ham, S.W.; Kang, M.J.; Park, Y.-M.; Oh, I.-Y.; Kim, B.K.; Im, T.-J.; Kim, S.-H.; Choi, Y.W.; Lee, J. Transdermal Penetration of Synthetic Peptides and Their Penetration Enhancement Caused by Some Terpene Compounds. Bull. Korean Chem. Soc. 2007, 28, 1535-1538. [CrossRef]

367. Tadwee, I.K.; Gore, S.; Giradkar, P. Advances in Topical Drug Delivery System: A Review. Int. J. Pharm. Res. Allied Sci. 2012, 1, 14-23.

368. Thong, H.-Y.; Zhai, H.; Maibach, H.I. Percutaneous Penetration Enhancers: An Overview. Skin Pharmacol. Physiol. 2007, 20, 272-282. [CrossRef] [PubMed]

369. Ahmadi Ashtiani, H.R.; Bishe, P.; Lashgari, N.; Nilforoushzadeh, M.A.; Zare, S. Liposomes in Cosmetics. J. Ski. Stem Cell 2016, 3 , e65815. [CrossRef]

370. Eskens, O.; Amin, S. Challenges and effective routes for formulating and delivery of epidermal growth factors in skin care. Int. J. Cosmet. Sci. 2020, 43, 123-130. [CrossRef]

371. Kathe, K.; Kathpalia, H. Film forming systems for topical and transdermal drug delivery. Asian J. Pharm. Sci. 2017, 12, 487-497. [CrossRef]

372. Gad, S.; Desoqi, M.; El-Sawy, H.; Khafagy, E.; Ghourab, M. Drug Delivery Systems for Topical treatment of Inflammatory Skin Diseases. Rec. Pharm. Biomed. Sci. 2021, 5, 59-64. [CrossRef]

373. Peña-Juárez, M.C.; Guadarrama-Escobar, O.R.; Escobar-Chávez, J.J. Transdermal Delivery Systems for Biomolecules. J. Pharm. Innov. 2021, 1-14. [CrossRef]

374. Castelletto, V.; Hamley, I.W.; Whitehouse, C.; Matts, P.J.; Osborne, R.; Baker, E.S. Self-Assembly of Palmitoyl Lipopeptides Used in Skin Care Products. Langmuir 2013, 29, 9149-9155. [CrossRef]

375. Reissmann, S. Cell penetration: Scope and limitations by the application of cell-penetrating peptides. J. Pept. Sci. 2014, 20, 760-784. [CrossRef] [PubMed] 
376. Fu, T.-K.; Kuo, P.-H.; Lu, Y.-C.; Lin, H.-N.; Wang, L.H.-C.; Lin, Y.-C.; Kao, Y.-C.; Lai, H.-M.; Chang, M.D.-T. Cell Penetrating Peptide as a High Safety Anti-Inflammation Ingredient for Cosmetic Applications. Biomolecules 2020, 10, 101. [CrossRef]

377. Ookubo, N.; Michiue, H.; Kitamatsu, M.; Kamamura, M.; Nishiki, T.; Ohmori, I.; Matsui, H. The transdermal inhibition of melanogenesis by a cell-membrane-permeable peptide delivery system based on poly-arginine. Biomaterials 2014, 35, 4508-4516. [CrossRef] [PubMed]

378. Kumar, S.; Zakrewsky, M.; Chen, M.; Menegatti, S.; Muraski, J.A.; Mitragotri, S. Peptides as skin penetration enhancers: Mechanisms of action. J. Control. Release 2015, 199, 168-178. [CrossRef]

379. Chen, M.; Gupta, V.; Anselmo, A.C.; Muraski, J.A.; Mitragotri, S. Topical delivery of hyaluronic acid into skin using SPACE-peptide carriers. J. Control. Release 2014, 173, 67-74. [CrossRef] [PubMed]

380. Pan, Q.; Yu, Y.; Chen, D.; Jiao, G.; Liu, X. Enhanced penetration strategies for transdermal delivery. Front. Chem. Sci. Eng. 2020, 14, 378-388. [CrossRef]

381. Yang, J.-A.; Kim, E.-S.; Kwon, J.H.; Kim, H.; Shin, J.H.; Yun, S.H.; Choi, K.Y.; Hahn, S.K. Transdermal delivery of hyaluronic acid-Human growth hormone conjugate. Biomaterials 2012, 33, 5947-5954. [CrossRef]

382. Patravale, V.B.; Mandawgade, S.D. Novel cosmetic delivery systems: An application update. Int. J. Cosmet. Sci. 2008, 30, 19-33. [CrossRef]

383. Bakshi, P.; Vora, D.; Hemmady, K.; Banga, A.K. Iontophoretic skin delivery systems: Success and failures. Int. J. Pharm. 2020, 586, 119584. [CrossRef]

384. Karimipour, D.J.; Karimipour, G.; Orringer, J.S. Microdermabrasion: An Evidence-Based Review. Plast. Reconstr. Surg. 2010, 125, 372-377. [CrossRef]

385. Zhou, Y.; Banga, A.K. Enhanced delivery of cosmeceuticals by microdermabrasion. J. Cosmet. Dermatol. 2011, 10, 179-184. [CrossRef] [PubMed]

386. Ahsan, H. Immunopharmacology and immunopathology of peptides and proteins in personal products. J. Immunoass. Immunochem. 2019, 40, 439-447. [CrossRef] [PubMed]

387. Slaga, T.J.; Snyder, P.W. Safety Assessment of Acetyl Hexapeptide-8 and Acetyl Hexapeptide-8 Amide as Used in Cosmetics. 2020. Available online: https://www.cir-safety.org/sites/default/files/acetyl122020revTR.pdf (accessed on 17 April 2021).

388. Faria-Silva, C.; Ascenso, A.; Costa, A.M.; Marto, J.; Carvalheiro, M.; Ribeiro, H.M.; Simões, S. Feeding the skin: A new trend in food and cosmetics convergence. Trends Food Sci. Technol. 2020, 95, 21-32. [CrossRef]

389. Kim, S.-K. Marine cosmeceuticals. J. Cosmet. Dermatol. 2014, 13, 56-67. [CrossRef] [PubMed]

390. Pimentel, F.B.; Alves, R.C.; Rodrigues, F.; Oliveira, M.B.P.P. Macroalgae-Derived Ingredients for Cosmetic Industry-An Update. Cosmetics 2018, 5, 2. [CrossRef]

391. Kang, N.J.; Jin, H.-S.; Lee, S.-E.; Kim, H.J.; Koh, H.; Lee, D.-W. New approaches towards the discovery and evaluation of bioactive peptides from natural resources. Crit. Rev. Environ. Sci. Technol. 2020, 50, 72-103. [CrossRef]

392. Rona, C.; Vailati, F.; Berardesca, E. The cosmetic treatment of wrinkles. J. Cosmet. Dermatol. 2004, 3, 26-34. [CrossRef] [PubMed]

393. Campiche, R.; Pascucci, F.; Jiang, L.; Vergne, T.; Cherel, M.; Gougeon, S.; Préstat-Marquis, E.; François, G.; Laurent, G.; Gempeler, M. Facial Expression Wrinkles and Their Relaxation by a Synthetic Peptide. Int. J. Pept. Res. Ther. 2020. [CrossRef]

394. Limbert, G.; Kuhl, E. On skin microrelief and the emergence of expression micro-wrinkles. Soft Matter 2018, 14, 1292-1300. [CrossRef]

395. Wang, Y.; Wang, M.; Xiao, X.S.; Huo, J.; Zhang, W.D. The anti-wrinkle efficacy of Argireline. J. Cosmet. Laser Ther. 2013, 15, 237-241. [CrossRef]

396. Wang, Y.; Wang, M.; Xiao, S.; Pan, P.; Li, P.; Huo, J. The Anti-Wrinkle Efficacy of Argireline, a Synthetic Hexapeptide, in Chinese Subjects. Am. J. Clin. Dermatol. 2013, 14, 147-153. [CrossRef]

397. Sanders, L. Anti-ageing actives and technologies behind them. Pers. Care Eur. 2019, 85-89.

398. Wongrattanakamon, P.; Nimmanpipug, P.; Sirithunyalug, B.; Jiranusornkul, S. Molecular modeling elucidates the cellular mechanism of synaptotagmin-SNARE inhibition: A novel plausible route to anti-wrinkle activity of botox-like cosmetic active molecules. Mol. Cell. Biochem. 2018, 442, 97-109. [CrossRef] [PubMed]

399. Li, Y.C.; Kavalali, E.T. Synaptic Vesicle-Recycling Machinery Components as Potential Therapeutic Targets. Pharmacol. Rev. 2017, 69, 141-160. [CrossRef]

400. Pohanka, M. Alpha7 Nicotinic Acetylcholine Receptor Is a Target in Pharmacology and Toxicology. Int. J. Mol. Sci. 2012, 13, 2219-2238. [CrossRef] [PubMed]

401. Thomas, J.R.; Dixon, T.K.; Bhattacharyya, T.K. Effects of Topicals on the Aging Skin Process. Facial Plast. Surg. Clin. N. Am. 2013, 21, 55-60. [CrossRef]

402. Mitchell, S. Best Peptide Face Creams. Available online: https://lumeskin.com/best-peptide-cream/ (accessed on 5 May 2021).

403. Prokopowicz, M.; Różycki, K.M. Innovation in cosmetics. World Sci. News 2017, 72, 448-456.

404. Lipotec VANISTRYL ${ }^{\circledR}$ Functional Ingredient. Available online: https:// cosmetics.specialchem.com/product/i-lipotec-vanistrylfunctional-ingredient (accessed on 5 May 2021).

405. Diehl, C. Peptides in cosmeceuticals. Ukr. J. Dermatol. Venereol. Cosmetol. 2019, 28-35. [CrossRef]

406. RobelynLabs ElastinMD Stretch Mark Repair. Available online: https://www.robelynlabs.com/shop/product_detail/elastinmdstretch-mark-repair-therapy\# (accessed on 5 May 2021).

407. Cheng, C.M. Cosmetic use of botulinum toxin type A in the elderly. Clin. Interv. Aging 2007, 2, 81-83. [CrossRef] 
408. Jensen, J.D.; Freeman, S.R.; Cohen, J.L. Botulinum Toxins. In Cosmetic Dermatology Products and Procedures; Draelos, Z.D., Ed.; John Wiley \& Sons, Ltd.: Oxford, UK, 2016; pp. 364-374, ISBN 978-1-118-65558-0.

409. Satriyasa, B.K. Botulinum toxin (Botox) A for reducing the appearance of facial wrinkles: A literature review of clinical use and pharmacological aspect. Clin. Cosmet. Investig. Dermatol. 2019, 12, 223-228. [CrossRef]

410. Rasetti-Escargueil, C.; Popoff, M.R. Engineering Botulinum Neurotoxins for Enhanced Therapeutic Applications and Vaccine Development. Toxins 2021, 13, 1. [CrossRef]

411. Carruthers, A.; Carruthers, J. Botulinum Toxin Products Overview. Available online: https://www.skintherapyletter.com/agingskin/botulinum-toxin-overview/?amp=1 (accessed on 17 May 2021).

412. França, K.; Kumar, A.; Fioranelli, M.; Lotti, T.; Tirant, M.; Roccia, M.G. The history of Botulinum toxin: From poison to beauty. Wien. Med. Wochenschr. 2017, 167, 46-48. [CrossRef]

413. Ganceviciene, R.; Liakou, A.I.; Theodoridis, A.; Makrantonaki, E.; Zouboulis, C.C. Skin anti-aging strategies. Dermatoendocrinol. 2012, 4, 308-319. [CrossRef] [PubMed]

414. Shanbhag, S.; Nayak, A.; Narayan, R.; Nayak, U.Y. Anti-aging and Sunscreens: Paradigm Shift in Cosmetics. Adv. Pharm. Bull. 2019, 9, 348-359. [CrossRef]

415. Coleman, W.P., III. Handbook of Cosmetic Science and Technology, 3rd ed.; Barel, A.O., Paye, M., Maibach, H.I., Eds.; Informa Healthcare USA, Inc.: New York, NY, USA, 2009; ISBN 978-1-4200-6963-1.

416. Nigam, P.K.; Nigam, A. Botulinum toxin. Indian J. Dermatol. 2010, 55, 8-14. [CrossRef]

417. Gallagher, C.J.; Ackerman, A. Botulinum Toxin: From Molecule to Medicine. In BotulinumToxins Cosmetic and Clinical Applications; Cohen, J.L., Ozog, D.M., Eds.; JohnWiley \& Sons Ltd.: Hoboken, NJ, USA, 2017; pp. 37-51, ISBN 9781118661864.

418. Samizadeh, S.; De Boulle, K. Botulinum neurotoxin formulations: Overcoming the confusion. Clin. Cosmet. Investig. Dermatol. 2018, 11, 273-287. [CrossRef]

419. Aoki, K.R. Review of a Proposed Mechanism for the Antinociceptive Action of Botulinum Toxin Type A. Neurotoxicology 2005, 26, 785-793. [CrossRef] [PubMed]

420. Grando, S.A.; Zachary, C.B. The non-neuronal and nonmuscular effects of botulinum toxin: An opportunity for a deadly molecule to treat disease in the skin and beyond. Br. J. Dermatol. 2018, 178, 1011-1019. [CrossRef]

421. Sethi, N.; Singh, S.; DeBoulle, K.; Rahman, E. A Review of Complications Due to the Use of Botulinum Toxin A for Cosmetic Indications. Aesthetic Plast. Surg. 2020, 45, 1210-1220. [CrossRef] [PubMed]

422. Small, R. Botulinum Toxin Injection for Facial Wrinkles. Am. Fam. Physician 2014, 90, 168-175.

423. Lim, S.H.; Sun, Y.; Thiruvallur Madanagopal, T.; Rosa, V.; Kang, L. Enhanced Skin Permeation of Anti-wrinkle Peptides via Molecular Modification. Sci. Rep. 2018, 8, 1596. [CrossRef]

424. Lourith, N.; Kanlayavattanakul, M. Biopolymeric agents for skin wrinkle treatment. J. Cosmet. Laser Ther. 2016, 18, 301-310. [CrossRef] [PubMed]

425. Lipotec ARGIRELINE ${ }^{\circledR}$ Peptide. Available online: https://www.lipotec.com/en/products/argireline-reg-peptide/\# (accessed on 17 May 2021).

426. Lipotec Argireline ${ }^{\circledR}$ Amplified Peptide. Available online: https://www.lipotec.com/en/products/argireline-reg-amplifiedpeptide/\# (accessed on 17 May 2021).

427. Grosicki, M.; Latacz, G.; Szopa, A.; Cukier, A.; Kieć-Kononowicz, K. The study of cellular cytotoxicity of argireline ${ }^{\circledR}$-An anti-aging peptide. Acta Biochim. Pol. 2014, 61, 29-32. [CrossRef]

428. Lipotec INYLINE ${ }^{\circledR}$ Peptide. Available online: https://www.lipotec.com/en/products/inyline-reg-peptide/\# (accessed on 17 May 2021).

429. Glass, D.J.; Bowen, D.C.; Stitt, T.N.; Radziejewski, C.; Bruno, J.; Ryan, T.E.; Gies, D.R.; Shah, S.; Mattsson, K.; Burden, S.J.; et al. Agrin Acts via a MuSK Receptor Complex. Cell 1996, 85, 513-523. [CrossRef]

430. Zong, Y.; Jin, R. Structural mechanisms of the agrin-LRP4-MuSK signaling pathway in neuromuscular junction differentiation. Cell. Mol. Life Sci. 2013, 70, 3077-3088. [CrossRef]

431. Zong, Y.; Zhang, B.; Gu, S.; Lee, K.; Zhou, J.; Yao, G.; Figueiredo, D.; Perry, K.; Mei, L.; Jin, R. Structural basis of agrin-LRP4-MuSK signaling. Genes Dev. 2012, 26, 247-258. [CrossRef] [PubMed]

432. McCarthy, K.J. Chapter Eight-The Basement Membrane Proteoglycans Perlecan and Agrin: Something Old, Something New. In Basement Membranes; Miner, J.H.B.T.-C.T. in M., Ed.; Academic Press: Cambridge, MA, USA, 2015; Volume 76, pp. 255-303, ISBN 1063-5823.

433. Bezakova, G.; Ruegg, M.A. New insights into the roles of agrin. Nat. Rev. Mol. Cell Biol. 2003, 4, 295-309. [CrossRef]

434. Miner, J.H.; Abrahamson, D.R. Molecular and Cellular Mechanisms of Glomerular Capillary Development. In Seldin and Giebisch's The Kidney Physiology and Pathophysiology; Alpern, R.J., Hebert, S.C.B.T.-S. and G.T.K. Fourth E., Eds.; Academic Press: San Diego, CL, USA, 2008; pp. 691-707, ISBN 978-0-12-088488-9.

435. Bezakova, G.; Helm, J.P.; Francolini, M.; Lømo, T. Effects of Purified Recombinant Neural and Muscle Agrin on Skeletal Muscle Fibers in Vivo. J. Cell Biol. 2001, 153, 1441-1452. [CrossRef]

436. Kim, N.; Stiegler, A.L.; Cameron, T.O.; Hallock, P.T.; Gomez, A.M.; Huang, J.H.; Hubbard, S.R.; Dustin, M.L.; Burden, S.J. Lrp4 Is a Receptor for Agrin and Forms a Complex with MuSK. Cell 2008, 135, 334-342. [CrossRef] 
437. Lipotec Inyline Peptide. A New Strategy to Escape from Expression Lines. Available online: https://www.google.it/url?sa=t\& $r c t=j \& q=\& e s r c=s \& s o u r c e=w e b \& c d=\& v e d=2 a h U K E w i e r t v o o M f w A h X i h v 0 H H f 8 v C p M Q F j A B e g Q I A x A D \& u r l=h t t p s \% 3 A \% 2 F \%$ 2Fwww.quickbox.com\%2Fwp-content\%2Fuploads\%2F2017\%2F04\%2FInyline.pdf\&usg=AOvVaw3-6g145MNLAmepiZqL6v9i (accessed on 17 May 2021).

438. Prospector BONT-L Peptide Solution (PF). Available online: https://www.ulprospector.com/en/eu/PersonalCare/Detail/1932 3/601512/BONT-L-Peptide-Solution-PF (accessed on 5 May 2021).

439. TAOS Inc. BoNT-L Peptide. Available online: https://www.technicalartofscience.com/product/bont-l-peptide/ (accessed on 10 May 2021).

440. Shahi, S.; Athawale, R.B. Development and evaluation of Cosmeceutical Nanolipogel. Res. J. Top. Cosmet. Sci. 2010, 1, 18-24.

441. Lipotec SNAP-8 ${ }^{\text {TM }}$ Peptide. Available online: https://www.lipotec.com/en/products/snap-8-trade-peptide/ (accessed on 17 May 2021).

442. Avcil, M.; Akman, G.; Klokkers, J.; Jeong, D.; Çelik, A. Efficacy of bioactive peptides loaded on hyaluronic acid microneedle patches: A monocentric clinical study. J. Cosmet. Dermatol. 2020, 19, 328-337. [CrossRef] [PubMed]

443. LIPOTEC. A GMP Peptide for Cosmetic Applications; LIPOTEC: Barcelona, Spain, 2005.

444. Infinitec $X 50^{\circledR}$ Myocept Lines of Expression: The Best Performance at Lowest Dose. Available online: https://infinitec.es/ technology / x50-myocept/ (accessed on 17 May 2021).

445. Dragomirescu, A.O.; Andoni, M.; Ionescu, D.; Andrei, F. The Efficiency and Safety of Leuphasyl-A Botox-Like Peptide. Cosmetics 2014, 1, 75-81. [CrossRef]

446. Park, J.; Jung, H.; Jang, B.; Song, H.-K.; Han, I.-O.; Oh, E.-S. D-tyrosine adds an anti-melanogenic effect to cosmetic peptides. Sci. Rep. 2020, 10, 262. [CrossRef] [PubMed]

447. Sederma Prospector Calmosensine ${ }^{\mathrm{TM}}$ SP. Available online: https://www.ulprospector.com/en/na/PersonalCare/Detail/1240/4 4014/Calmosensine-SP (accessed on 17 May 2021).

448. Sederma Calmosensine. Available online: https:/ $/ w w w \cdot g o o g l e . i t / u r l ? s a=t \& r c t=j \& q=\& e s r c=s \& s o u r c e=w e b \& c d=\& v e d=$ 2ahUKEwiGgL6misnwAhUEKuwKHfJQBuAQFjABegQIAhAD\&url=https\%3A\%2F\%2Fwww.bio-therapeutic.com\%2Fwpcontent\%2Fuploads\%2F2017\%2F08\%2FCHROMATIC_SERUM_WHITE_PAPERS.pdf\&usg=AOvVaw0eY9TgKPNJeXcR9 JdpYhM (accessed on 29 April 2021).

449. Khmaladze, I.; Österlund, C.; Smiljanic, S.; Hrapovic, N.; Lafon-Kolb, V.; Amini, N.; Xi, L.; Fabre, S. A novel multifunctional skin care formulation with a unique blend of antipollution, brightening and antiaging active complexes. J. Cosmet. Dermatol. 2020, 19, 1415-1425. [CrossRef]

450. BASF Care Creations; BASF Myoxinol ${ }^{\circledR}$ LS 9736. Available online: https:/ / carecreations.basf.us/products/myoxinol-1s-9736 (accessed on 17 May 2021).

451. Renzi, A.; Brillantino, A.; Di Sarno, G.; D’Aniello, F.; Ziccardi, S.; Paladino, F.; Iacobellis, F. Myoxinol (Hydrolyzed Hibiscus esculentus Extract) in the Cure of Chronic Anal Fissure: Early Clinical and Functional Outcomes. Gastroenterol. Res. Pract. 2015, 2015, 567920. [CrossRef]

452. Benoit, I.; Danoux, L.; Gillon, V.; Moussou, P.; Pauly, G. Oligopeptides from Hibiscus esculentus seeds to smooth expression lines. SOFW J. 2004, 130, 64-71.

453. Prospector Myoxinol ${ }^{\mathrm{TM}}$ LS 9736. Available online: https://www.ulprospector.com/en/na/PersonalCare/Detail/75/109267/ Myoxinol-LS-9736 (accessed on 17 May 2021).

454. Alqasoumi, S.I. ‘Okra' Hibiscus esculentus L.: A study of its hepatoprotective activity. Saudi Pharm. J. 2012, 20, 135-141. [CrossRef] [PubMed]

455. BASF Anti-wrinkle Eye Care Serum. Available online: https://www.carecreations.basf.com/product-formulations / formulations / formulations-detail/Anti-wrinkleEyecareSerum/sc-de-12-108-9 (accessed on 17 May 2021).

456. A Natural Alternative to Botulinum Toxin. Available online: https://www.cosmeticsdesign.com/Article/2004/03/10/A-naturalalternative-to-botulinum-toxin (accessed on 17 May 2021).

457. BASF Care Creations Myoxinol The Vegetal Answer to Smooth Expression Lines. Available online: https://www.google.it/url?sa= $t \& r c t=j \& q=\& e s r c=s \& s o u r c e=w e b \& c d=\& c a d=r j a \& u a c t=8 \& v e d=2 a h U K E w i O 5 r y e h J \_w A h U N M-w K H b b A C W E Q F n o E C A I Q A A \&$ url=https\%253A\%252F\%252Fbiakhim.com.ua\%252Findex.php\%253Foption\%253Dcom_k2\%2526Itemid\%253D1173\%2526id\%25 3D668_30edae9b008c91727b8d (accessed on 17 May 2021).

458. Barbosa, A.F.; De Carvalhoa, M.G.; Smith, R.E.; Sabaa-Srur, A.U.O. Spilanthol: Occurrence, extraction, chemistry and biological activities. Rev. Bras. Farmacogn. 2016, 26, 128-133. [CrossRef]

459. Silveira, N.; Sandjo, L.P.; Biavatti, M.W. Spilanthol-containing products: A patent review (1996-2016). Trends Food Sci. Technol. 2018, 74, 107-111. [CrossRef]

460. Sabitha Rani, A.; Sana, H.; Sulakshana, G.; Keerti, E.; Shravya Puri, M. Spilanthes acmella- an important medicinal plant. Int. J. Minor Fruits Med. Aromat. Plants 2019, 5, 15-26.

461. Artaria, C.; Maramaldi, G.; Bonfigli, A.; Rigano, L.; Appendino, G. Lifting properties of the alkamide fraction from the fruit husks of Zanthoxylum bungeanum. Int. J. Cosmet. Sci. 2011, 33, 328-333. [CrossRef] [PubMed]

462. Demarne, F.; Passaro, G. Use of an Acmella oleracea extract for the botulinum toxin-like effect thereof in an anti-wrinkle cosmetic composition. U.S. Patent No 7,531,193, 12 May 2009. 
463. Yang, D.; Li, W.; Fang, L.; Liu, C. Investigation of Controlled Release Molecular Mechanism of Oil Phase in Spilanthol Emulsion: Development and In Vitro, In Vivo Characterization. AAPS PharmSciTech 2019, 20, 227. [CrossRef] [PubMed]

464. Boonen, J.; Baert, B.; Roche, N.; Burvenich, C.; De Spiegeleer, B. Transdermal behaviour of the N-alkylamide spilanthol (affinin) from Spilanthes acmella (Compositae) extracts. J. Ethnopharmacol. 2010, 127, 77-84. [CrossRef]

465. Surianarayanan, R.; Bhaskar, J.P. Herbal Cosmeceuticals. In Plant Metabolites: Methods, Applications and Prospects; Sukumaran, S.T., Sugathan, S., Abdulhameed, S., Eds.; Springer Nature: Singapore, 2020; pp. 217-238, ISBN 978-981-15-5136-9.

466. Santana, M.; Oliveira, G.; Yoshida, V.; Sabha, M.; Oshima-Franco, Y. Naturally occurring ingredients as potential antiaging cosmetics. Lat. Am. J. Pharm. 2011, 30, 1531-1535.

467. Muszyńska, B.; Fijałkowska, A.; Sułkowska-Ziaja, K.; Włodarczyk, A.; Kaczmarczyk, P.; Nogaj, E.; Piętka, J. Fomitopsis officinalis: A Species of Arboreal Mushroom with Promising Biological and Medicinal Properties. Chem. Biodivers. 2020, 17, e2000213. [CrossRef] [PubMed]

468. Widowati, W.; Fauziah, N.; Herdiman, H.; Afni, M.; Afifah, E.; Sari, H.W.K.; Nufus, H.; Arumwardana, S.; Rihibiha, D.D. Antioxidant and Anti Aging Assays of Oryza Sativa Extracts, Vanillin and Coumaric Acid. J. Nat. Remedies 2016, 16, 88-99. [CrossRef]

469. Apostolopoulos, V.; Bojarska, J.; Chai, T.-T.; Elnagdy, S.; Kaczmarek, K.; Matsoukas, J.; New, R.; Parang, K.; Lopez, O.P.; Parhiz, H.; et al. A Global Review on Short Peptides: Frontiers and Perspectives. Molecules 2021, 26, 430. [CrossRef]

470. Ctpa Cosmetic Product Claims Regulatory Framework. Available online: https://www.ctpa.org.uk/resources-claims (accessed on 17 May 2021).

471. Ctpa NEW-CTPA Guide to Advertising Claims. Available online: https://www.ctpa.org.uk/news/new-ctpa-guide-toadvertising-claims-4080 (accessed on 17 May 2021).

472. Nohynek, G.J.; Antignac, E.; Re, T.; Toutain, H. Safety assessment of personal care products/cosmetics and their ingredients. Toxicol. Appl. Pharmacol. 2010, 243, 239-259. [CrossRef]

473. Dent, M.; Amaral, R.T.; Da Silva, P.A.; Ansell, J.; Boisleve, F.; Hatao, M.; Hirose, A.; Kasai, Y.; Kern, P.; Kreiling, R.; et al. Principles underpinning the use of new methodologies in the risk assessment of cosmetic ingredients. Comput. Toxicol. 2018, 7, 20-26. [CrossRef]

474. Juncan, A.M. Packaging Evaluation and Safety Assessment of a Cosmetic Product. Mater. Plast. 2018, 55, 644. [CrossRef]

475. Juncan, A.M.; Rus, L.L. Influence of Packaging and Stability Test Assessment of an Anti-aging Cosmetic Cream. Mater. Plast. 2018, 55, 426. [CrossRef]

476. Lionetti, N.; Rigano, L. Labeling of Cosmetic Products. Cosmetics 2018, 5, 22. [CrossRef]

477. ARKANA. ARKANA Advanced Beauty Care. Available online: https://arkanacosmetics.com/ (accessed on 17 May 2021).

478. ARKANA Bo2Look Elixir $20 \mathrm{ml}$. Available online: https:/ /www.shop-arkana.com/b2c_en/bo2look-elixir-20-ml.html (accessed on 17 May 2021).

479. Turner, A.; Kaas, Q.; Craik, D.J. Hormone-like conopeptides-New tools for pharmaceutical design. RSC Med. Chem. 2020, 11, 1235-1251. [CrossRef]

480. BCR Biocomponent Research Activen XEP ${ }^{\mathrm{TM}}$-018. Available online: https://www.bcringredients.com/activen-xep-018/ (accessed on 17 May 2021).

481. Pennington, M.W.; Czerwinski, A.; Norton, R.S. Peptide therapeutics from venom: Current status and potential. Bioorg. Med. Chem. 2018, 26, 2738-2758. [CrossRef]

482. Schroeder, C.I.; Craik, D.J. Therapeutic potential of conopeptides. Future Med. Chem. 2012, 4, 1243-1255. [CrossRef] [PubMed]

483. Activen Discover Cone Snail Peptidomimetic, the Revolutionary Anti-Wrinkles. Instant Line Relaxer. Available online: http: / / www.activen.ch/?page=xep (accessed on 17 May 2021).

484. Favreau, P.; Benoit, E.; Hocking, H.G.; Carlier, L.; D’hoedt, D.; Leipold, E.; Markgraf, R.; Schlumberger, S.; Córdova, M.A.; Gaertner, H.; et al. A novel $\mu$-conopeptide, CnIIIC, exerts potent and preferential inhibition of NaV1.2/1.4 channels and blocks neuronal nicotinic acetylcholine receptors. Br. J. Pharmacol. 2012, 166, 1654-1668. [CrossRef]

485. Bjørn-Yoshimoto, W.E.; Ramiro, I.B.L.; Yandell, M.; McIntosh, J.M.; Olivera, B.M.; Ellgaard, L.; Safavi-Hemami, H. Curses or Cures: A Review of the Numerous Benefits Versus the Biosecurity Concerns of Conotoxin Research. Biomedicines 2020, 8, 235. [CrossRef] [PubMed]

486. Del Río-Sancho, S.; Cros, C.; Coutaz, B.; Cuendet, M.; Kalia, Y.N. Cutaneous iontophoresis of $\mu$-conotoxin CnIIIC-A potent NaV1.4 antagonist with analgesic, anaesthetic and myorelaxant properties. Int. J. Pharm. 2017, 518, 59-65. [CrossRef]

487. Elixseri Cone Snail Peptide/XEP ${ }^{\mathrm{TM}}$ - 018. Available online: https:/ / www.elixseri.com/pta-cone-snail-peptide (accessed on 17 May 2021).

488. ARKANA Neuro GABA \& NANA Therapy. Available online: https://arkanacosmetics.com/md/neuro-gabanana-therapy/ (accessed on 17 May 2021).

489. ARKANA Neuro GABA Therapy. Available online: https://www.shop-arkana.com/b2b_en/linie-arkana/neuro-gaba-nanatherapy.html (accessed on 17 May 2021).

490. Ferrillo, M.; Vastarella, M.; Cantelli, M.; Mazzella, C.; Fabbrocini, G. Instrumental, clinical and subjective evaluation of the efficacy of a cosmetic treatment for home use. J. Cosmet. Laser Ther. 2019, 21, 190-195. [CrossRef]

491. Mittapally, S.; Afnan, A.A. A review on nanotechnology in cosmetics. Pharma Innov. J. 2019, 8, 668-671. 
492. Chan, G.; Wong, Z.; Lam, K.; Cheng, L.; Zhang, L.; Lin, H.; Dong, T.; Tsim, K. Edible Bird's Nest, an Asian Health Food Supplement, Possesses Skin Lightening Activities: Identification of N-Acetylneuraminic Acid as Active Ingredient. J. Cosmet. Dermatol. Sci. Appl. 2015, 5, 262-274. [CrossRef]

493. Lodén, M. Moisturizers: Treatment of Dry Skin Syndrome and Barrier Defects. In Cosmeceuticals and Active Cosmetics; Sivamani, R.K., Jagdeo, J.R., Elsner, P., Maibach, H.I., Eds.; CRC Press: Boca Raton, FL, USA, 2016; pp. 235-259, ISBN 9780429192388.

494. Green, B.A.; Van Scott, E.J.; Yu, R.J. Clinical Uses of Hydroxyacids. In Cosmetic Dermatology Products and Procedures; Draelos, Z.D., Ed.; Wiley-Blackwell: Hoboken, NJ, USA, 2016; pp. 346-356, ISBN 978-1-118-65558-0.

495. ARKANA Professional CARBO V RECONSTRUCTOR. Available online: https://arkanaukprof.com/product/carbo-vreconstructor / (accessed on 17 May 2021).

496. Sparavigna, A.; Tenconi, B.; De Ponti, I.; Guglielmini, G. Evaluation of the Activity and Tolerability of a Cosmetic Treatment for the Periocular Area on the Aging Face: Controlled Clinical and Instrumental Evaluation vs. Placebo. Cosmetics 2014, 1, 105-116. [CrossRef]

497. Prospector Ximilene ${ }^{\circledR}$. Available online: https://www.ulprospector.com/en/eu/PersonalCare/Detail/2736/90649/Ximilene (accessed on 17 May 2021).

498. Satoto, G.; Fernandes, A.S.; Saraiva, N.; Santos, F.; Neng, N.; Nogueira, J.M.; Santos de Almeida, T.; Araujo, M.E. An Overview on the Properties of Ximenia Oil Used as Cosmetic in Angola. Biomolecules 2020, 10, 18. [CrossRef] [PubMed]

499. Belcaro, G.; Dugall, M.; Maramaldi, G.; Togni, S.; Giacomelli, L. Evaluation of the efficacy of a new escin-based, multi-component formulation in reducing eyelid edema. Minerva Oftalmol. 2016, 58, 65-69.

500. Vermaak, I.; Kamatou, G.P.P.; Komane-Mofokeng, B.; Viljoen, A.M.; Beckett, K. African seed oils of commercial importanceCosmetic applications. S. Afr. J. Bot. 2011, 77, 920-933. [CrossRef]

501. Shivatare, R.S.; Musale, R.; Lohakare, P.; Patil, D.; Choudhary, D.; Ganu, G.; Nagore, D.H.; Kewatkar, S.M. Isolation, Identification and Characterization of Ximenynic Acid with Anti-Aging Activity from Santalum Album. Int. J. Res. Pharm. Sci. 2020, 11, 1394-1399. [CrossRef]

502. The Derm Review Amino Acids In Skincare: Arginine. Available online: https://thedermreview.com/arginine/ (accessed on 17 May 2021).

503. BE BEAUTIFUL. What Is the Role of Arginine in Skincare. Available online: https://www.bebeautiful.in/all-things-skin/ everyday/arginine-in-skincare (accessed on 17 May 2021).

504. ARKANA Biomimetic Therapy—The Way to Regain Youth. Available online: https://arkanacosmetics.com/news/biomimetictherapy-the-way-to-regain-youth/ (accessed on 17 May 2021).

505. Prospector Adipofill'in ${ }^{\mathrm{TM}}$. Available online: https://www.ulprospector.com/en/eu/PersonalCare/Detail/4499/215014/ Adipofillin (accessed on 17 May 2021).

506. LucasMeyer-Cosmetics L-Ornithine Vectorized in a Ionosome ${ }^{\mathrm{TM}}$. Available online: https://www.lucasmeyercosmetics.com/en/ node/578 (accessed on 10 May 2021).

507. DeJohn, A. Volumizing Anti-aging Skin Care Ingredient. Available online: https://www.cosmeticsdesign.com/Article/2012/06/ 13/Volumizing-anti-aging-skin-care-ingredient (accessed on 10 May 2021).

508. LucasMeyer-Cosmetics. Adipofill Bio-controlled Lipofilling. LucasMeyer-Cosmetics. Available online: www.lucasmeyercosmetics. com (accessed on 6 May 2021).

509. Harada, D.; Nagamachi, S.; Aso, K.; Ikeda, K.; Takahashi, Y.; Furuse, M. Oral administration of 1-ornithine increases the content of both collagen constituting amino acids and polyamines in mouse skin. Biochem. Biophys. Res. Commun. 2019, 512, 712-715. [CrossRef] [PubMed]

510. Loing, E.; Belhaj, N.; Ollier, V.; Bezivin, C. New generation of resistant delivery system for a better skin bioavailability and anti-aging targeted action. Available online: https://www.scconline.org/wp-content/uploads/2014/10/Loing.pdf (accessed on 10 June 2021).

511. Stanek, J.; Wochner, M.; Gupta, S. Current and Future 'Body-sculpting'Cosmetics. CoValence Lab. Res. CT 2015, 130, $20-31$.

512. Rattan, S.I.S. Hormetic Mechanisms of Anti-Aging and Rejuvenating Effects of Repeated Mild Heat Stress on Human Fibroblasts in Vitro. Rejuvenation Res. 2004, 7, 40-48. [CrossRef] [PubMed]

513. Hu, S.; Han, M.; Rezaei, A.; Li, D.; Wu, G.; Ma, X. L-Arginine Modulates Glucose and Lipid Metabolism in Obesity and Diabetes. Curr. Protein Pept. Sci. 2017, 18, 599-608. [CrossRef] [PubMed]

514. Rattan, S.I.S.; Kryzch, V.; Schnebert, S.; Perrier, E.; Nizard, C. Hormesis-Based Anti-Aging Products: A Case Study of a Novel Cosmetic. Dose Response 2012, 11. [CrossRef]

515. Rattan, S.I.S. Hormetins as Novel Components of Cosmeceuticals and Aging Interventions. Cosmetics 2015, 2, 11-20. [CrossRef]

516. Does the Beauty Industry Need to Become More Transparent with Consumers? Available online: https://uk.fashionnetwork. $\mathrm{com} /$ news / Does-the-beauty-industry-need-to-become-more-transparent-with-consumers-,992826.html (accessed on $17 \mathrm{May}$ 2021).

517. The Provenance Team Transparency in Beauty \& Wellness: Why 2020 Will be a Breakthrough Year. Available online: https: //www.provenance.org/news/movement/transparency-in-beauty-wellness-why-2020-will-be-a-breakthrough-year (accessed on 10 May 2021). 
518. Rachel Brown Consumers Are Demanding Greater Transparency From Beauty Brands. What Does That Really Mean? Available online: https: / / www.beautyindependent.com/consumers-are-demanding-greater-transparency-from-beauty-brands-whatdoes-that-really-mean/ (accessed on 10 May 2021).

519. Optel Transparency and Quality Guarantee for the Cosmetics Industry. Consumer Expectations: More Than Skin Deep. Available online: https:/ / www.optelgroup.com/cosmetic-industry/ (accessed on 10 May 2021).

520. Manteghi, M. European Cosmetics Industry: Main Aspects and Regulation. SSRN 2017, 21. [CrossRef]

521. U.S. Food \& Drug Administration Summary of Cosmetics Labeling Requirements. Available online: https://www.fda.gov/ cosmetics / cosmetics-labeling-regulations/summary-cosmetics-labeling-requirements (accessed on 17 May 2021).

522. Cosmetics Europe Understanding the Label. Available online: https://cosmeticseurope.eu/cosmetic-products/understandinglabel/ (accessed on 17 May 2021).

523. Canada, G. of Industry Guide for the Labelling of Cosmetics. Available online: https://www.canada.ca/en/health-canada/ services / consumer-product-safety/reports-publications/industry-professionals/labelling-cosmetics.html (accessed on 10 May 2021).

524. European Commission Cosmetic Products—Specific Topics. Available online: https:/ / ec.europa.eu/growth/sectors/cosmetics/ products_en (accessed on 17 May 2021).

525. Dorato, S. Chapter 1-General Concepts: Current Legislation on Cosmetics in Various Countries; Salvador, A., Chisvert, A.B.T.-A., Eds.; Elsevier: Boston, MA, USA, 2018; pp. 3-37, ISBN 978-0-444-63508-2.

526. EUR-Lex Access to European Union Law Commission Regulation (EU) No 655/2013 of 10 July 2013 Laying Down Common Criteria for the Justification of Claims Used in Relation to Cosmetic Products Text with EEA Relevance. Available online: https:/ / eur-lex.europa.eu/legal-content/EN/ALL/?uri=CELEX:32013R0655 (accessed on 17 May 2021).

527. European Commission Technical Document on Cosmetic Claims. Available online: https://ec.europa.eu/docsroom/documents/ 24847 (accessed on 17 May 2021).

528. Ctpa Cosmetic Product Definition. Available online: https://www.ctpa.org.uk/definition-ofa-cosmetic (accessed on 17 May 2021).

529. European Commission Cosmetics. Available online: https:/ / ec.europa.eu/growth/sectors/cosmetics_en (accessed on 17 May 2021).

530. European Commission Legislation. Available online: https:/ / ec.europa.eu/growth/sectors/cosmetics/legislation_en (accessed on 17 May 2021).

531. European Commission Manual of the Working Group on Cosmetic Products (Sub-Group on Borderline Products) on the Scope of Application of the Cosmetics Regulation (EC) No 1223/2009 (ART. 2(1)(A)) Version 3.1. Available online: https: / / ec.europa.eu/docsroom/documents/29002 (accessed on 17 May 2021).

532. Parliament, E. Question Reference: E-000056/2016. Available online: https://www.europarl.europa.eu/doceo/document/E-8 2016-000056-ASW_EN.html?redirect (accessed on 12 May 2021).

533. EUR-Lex Access to European Union Law Consolidated text: Directive 2001/83/EC of the European Parliament and of the Council of 6 November 2001 on the Community Code Relating to Medicinal Products for Human Use. Available online: https: / / eur-lex.europa.eu/eli/dir/2001/83/2019-07-26 (accessed on 17 May 2021).

534. EUR-Lex Access to European Union Law Consolidated text: Regulation (EU) No 528/2012 of the European Parliament and of the Council of 22 May 2012 Concerning the Making Available on the Market and Use of Biocidal Products (Text with EEA relevance) Text with EEA Relevance. Available online: https:/ / eur-lex.europa.eu/legal-content/EN/TXT/?uri=CELEX\%3A02012R0528-20 210329 (accessed on 17 May 2021).

535. EUR-Lex Access to European Union Law Consolidated text: Regulation (EU) 2017/745 of the European Parliament and of the Council of 5 April 2017 on Medical Devices, Amending Directive 2001/83/EC, Regulation (EC) No 178/2002 and Regulation (EC) No 1223/2009 and Repealing Council Directives 90/3. Available online: https:/ / eur-lex.europa.eu/legal-content/EN/TXT/ ?uri=CELEX\%3A02017R0745-20200424 (accessed on 17 May 2021).

536. European Commission Borderline Products. Available online: https://ec.europa.eu/growth/sectors/cosmetics/products/ borderline-products_en (accessed on 17 May 2021). 